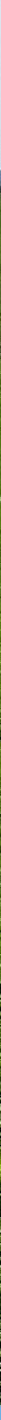

\title{
Wat zijn de mogelijkheden om een leverbotinfectie bij melkvee te voorkomen?
}





\section{Wat zijn de mogelijkheden om een leverbotinfectie van melkvee te voorkomen?}

Francesca Neijenhuis ${ }^{1}$, Cynthia Verwer ${ }^{2}$, Jan Verkaik ${ }^{1}$

1 Wageningen Livestock Research

2 Louis Bolk Instituut

Dit onderzoek is uitgevoerd door Wageningen Livestock Research en het Louis Bolk Instituut, in opdracht van, en gefinancierd door, het Ministerie van Economische Zaken, in het kader van het Beleidsondersteunend onderzoek thema 'AgroFood Duurzame Veehouderij' (projectnummer BO-22.04-007-001)

Wageningen Livestock Research, Louis Bolk Instituut

Wageningen, Driebergen, juni 2017

Rapport 1029 
Neijenhuis, F., C. Verwer, J. Verkaik, 2017. Wat zijn de mogelijkheden om een leverbotinfectie van melkvee te voorkomen? Wageningen Livestock Research, Louis Bolk Instituut, Rapport 1029.

Samenvatting NL Infecties met leverbot zijn in toenemende mate een knelpunt in de diergezondheid van grazende (of vers gras gevoerde) herkauwers. Leverbotinfectie leidt tot ziekte met economische gevolgen en voor melkgevende dieren zijn geen anthelmintica vrij beschikbaar. In dit project is het leverbotinstrument ontwikkeld met als doel om veehouders inzicht en handelingsperspectief te geven ten aanzien van de leverbotsituatie op hun bedrijf. In dit rapport worden de resultaten van het leverbotinstrument weergegeven en van een drietal preventieve maatregelen die zijn uitgeprobeerd.

Summary UK Liverfluke infections are increasingly a bottleneck in the animal health of grazing (or fresh grass fed) ruminants. Liverfluke leads to disease with economic consequences and for lactating animals no anthelmintics are freely available. This project has been working on the development of the liverfluke instrument with the aim of providing dairy farmers insight and action perspective regarding the liverfluke situation on their farm. This report presents the results of the liverfluke instrument and of three preventive measures that have been investigated.

Dit rapport is gratis te downloaden op http://dx.doi.org/10.18174/417665 of op www.wur.nl/livestock-research (onder Wageningen Livestock Research publicaties) of via www.louisbolk.org (onder Publicaties).

(C) 2017 Wageningen Livestock Research

Postbus 338, 6700 AH Wageningen, T 03174839 53, E info.livestockresearch@wur.nl, www.wur.nl/livestock-research. Wageningen Livestock Research is onderdeel van Wageningen University \& Research.

(C) 2017 Louis Bolk Instituut

Hoofdstraat 24, 3972 LA Driebergen, T 03435238 60, E info@louisbolk.nl, www.louisbolk.org

Wageningen Livestock Research en Louis Bolk Instituut aanvaarden geen aansprakelijkheid voor eventuele schade voortvloeiend uit het gebruik van de resultaten van dit onderzoek of de toepassing van de adviezen.

Alle rechten voorbehouden. Niets uit deze uitgave mag worden vermenigvuldigd en/of openbaar gemaakt worden door middel van druk, fotokopie, microfilm of op welke wijze dan ook zonder voorafgaande toestemming van de uitgever of auteurs.

De certificering volgens ISO 9001 door DNV onderstreept ons kwaliteitsniveau. Op al onze onderzoeksopdrachten zijn de Algemene Voorwaarden van de Animal Sciences Group van toepassing. Deze zijn gedeponeerd bij de Arrondissementsrechtbank Zwolle.

Wageningen Livestock Research, Louis Bolk Instituut, Rapport 1029 


\section{Inhoud}

$\begin{array}{lr}\text { Woord vooraf } & 7\end{array}$

$\begin{array}{lr}\text { Samenvatting } & 9\end{array}$

$\begin{array}{lr}\text { Summary } & 13\end{array}$

$\begin{array}{lr}1 & 15\end{array}$

$2 \quad$ Leverbotinstrument (versie 2) $\quad 19$

$\begin{array}{lll}2.1 & \text { Leverbotinstrument en scoresysteem } & 19\end{array}$

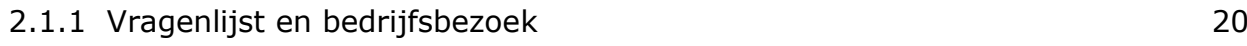

2.1.2 Monitoring van leverbotantistoffen 20

$3 \quad$ Methoden vaststellen besmetting $\quad 21$

3.1 Aanwezigheid van leverbotslak, trilhaarlarve en cercaria $\quad 21$

$\begin{array}{ll}3.1 .1 & \text { Biotoop en indicatorplanten }\end{array}$

$\begin{array}{ll}3.1 .2 \text { Karteren } & 21\end{array}$

$\begin{array}{ll}\text { 3.1.3 Vastellen van besmetting percelen } & 21\end{array}$

$\begin{array}{lll}3.2 & \text { Eitelling in mest } & 22\end{array}$

$\begin{array}{lll}3.3 & \text { Titerbepaling in bloed } & 22\end{array}$

$\begin{array}{lll}3.4 & \text { Titerbepaling in tankmelk } & 23\end{array}$

3.5 Beoordeling lever van afgevoerde dieren $\quad 23$

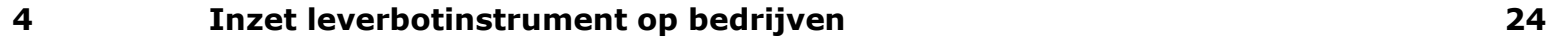

$\begin{array}{lll}4.1 & \text { Bedrijven selectie en verzamelde data } & 24\end{array}$

4.1.1 Bloedtiters van verschillende groepen dieren $\quad 27$

$\begin{array}{lll}4.2 & \text { Analyse } & 28\end{array}$

$\begin{array}{lll}4.3 & \text { Uitkomsten } & 28\end{array}$

4.3.1 Algemene bedrijfstypering en kengetallen 29

4.3.2 Reguliere en preventieve bestrijdingsmaatregelen 29

4.3.3 Kennis van de veehouder 30

$\begin{array}{ll}\text { 4.3.4 Perceelsituatie en beweiding } & 30\end{array}$

4.3.5 Leverbothistorie en actuele besmetting 30

$\begin{array}{lll}4.4 & \text { Resultaten melkvee en jongvee } & 30\end{array}$

$\begin{array}{lll}\text { 4.4.1 Resultaten jongvee } & 31\end{array}$

$\begin{array}{ll}\text { 4.4.2 Resultaten melkvee } & 31\end{array}$ 
5.1 Greppels frezen in de zomer 33

$\begin{array}{lll}5.1 .1 & \text { Doel } & 33\end{array}$

$\begin{array}{lll}5.1 .2 & \text { Aanpak } & 33\end{array}$

$\begin{array}{ll}5.1 .3 \text { Proefverslag } & 34\end{array}$

5.1.4 Conclusies, discussie en aanbevelingen 38

5.2 Ontwijkend beweiden (op basis van 'uitrasteren') en verhogen weerstand 40

$\begin{array}{ll}\text { 5.2.1 Doel } & 40\end{array}$

$\begin{array}{ll}\text { 5.2.2 Aanpak } & 40\end{array}$

$\begin{array}{ll}5.2 .3 \text { Acties } & 41\end{array}$

5.2.4 Monitoring effect besmettingsontwijkend weiden in de zomer 2015

5.2.5 Conclusies, discussie en aanbevelingen $\quad 42$

5.3 Ontwijkend beweiden (op basis van karteren) en inzet van loopeenden 42

5.3.1 Ontwijkend beweiden jongvee en melkvee 43

5.3.2 Inzet loopeenden ten behoeve van beperken en voorkomen leverbotslak en doorbreken van de leverbotcyclus 43

5.3.3 Praktische aspecten gebruik loopeenden $\quad 44$

$\begin{array}{ll}\text { 5.3.4 Conclusies } & 44\end{array}$

6 Toepasbare kennis om besmetting met leverbot te voorkomen 46

$\begin{array}{lll}6.1 & \text { Leverbotinstrument } & 46\end{array}$

$\begin{array}{lll}6.2 & \text { Besmetting vaststellen } & 46\end{array}$

6.2.1 Identificeren leverbotgevoelig perceel $\quad 46$

6.2.2 Besmetting van dieren vaststellen $\quad 46$

$\begin{array}{lll}\text { 6.3 Behandelen van besmette dieren } & 47\end{array}$

6.4 Maatregelen ter voorkoming van leverbotbesmetting $\quad 49$

$\begin{array}{ll}6.4 .1 & \text { Zomerfrezen }\end{array}$

6.4.2 Ontwijkend beweiden op basis van "uitrasteren" 49

6.4.3 Aanvoer, jongvee opfok en inscharen $\quad 49$

6.4.4 Preventieve maatregelen algemeen $\quad 49$

$7 \quad$ Discussie en conclusie $\quad 50$

$\begin{array}{lll}7.1 & \text { Schade } & 50\end{array}$

$\begin{array}{ll}7.1 .1 \text { Melkgift } & 50\end{array}$

$\begin{array}{ll}7.1 .2 \text { Fertiliteit } & 50\end{array}$ 
7.1.5 Algemeen onderzoeksbeeld

7.2 Risico op besmetting

7.3 Vaststelling besmetting

7.4 Behandeling

7.5 Conclusie vanuit de uitgeprobeerde preventieve maatregelen

7.5.1 Karteren

7.5.2 Zomerfrezen

7.5.3 Ontwijkend beweiden en maaien

7.7 Praktische aanbevelingen 


\section{Woord vooraf}

Leverbot kan leiden tot aanzienlijke economische schade en is een veel voorkomend probleem op melkveebedrijven, omdat weidepercelen de habitat kunnen vormen voor de tussengastheer, het leverbotslakje. Door gebrek aan geregistreerde diergeneesmiddelen voor melkgevende dieren is het van belang om met behulp van preventieve maatregelen infecties te voorkomen. In dit project is een instrument ontwikkeld dat inzicht kan geven in het risico dat een bedrijf loopt op een besmetting met leverbot. Uit dit instrument kunnen tevens handvatten naar voren komen om dat risico zo veel mogelijk te beperken. Mogelijk preventief werkende maatregelen die door veehouders zijn aangedragen tijdens diverse bijeenkomsten zijn in de praktijk getest. Naast het uittesten van deze maatregelen heeft een student op kleine schaal onderzoek gedaan naar de levenswijze van de slak en verschillende methoden om deze af te doden.

We waren niet in staat geweest om al dit werk uit te voeren zonder de inzet van de vele veehouders die veel tijd, kennis en informatie hebben bijgedragen aan de totstandkoming van het instrument en de uitvoering van de maatregelen. Het zijn er te veel om hier te noemen, maar allen hartelijk dank daarvoor! Voorts bedanken we Merial voor de werving van melkveehouders en het beschikbaar stellen van de historische tankmelkdata van deze bedrijven voor de bedrijvenselectie. We willen bij deze ook de student, Erwin Haveman, en zijn begeleiders bij PPP-AGRO en het VIC bedanken voor hun bijdragen. Ook hartelijk dank aan De Natuurweide voor het werven van veehouders voor deelname aan dit project en de financiële bijdrage. 
8 Wageningen Livestock Research, Louis Bolk Instituut, rapport 1029 


\section{Samenvatting}

Leverbot lijkt steeds vaker een knelpunt te zijn in de diergezondheid van grazende (of vers gras gevoerde) herkauwers. Leverbot kan leiden tot ziekte met productieverliezen. Een van de problemen is dat tegenwoordig zowel lacterende als droogstaande dieren niet kunnen worden behandeld omdat daarvoor geen middelen vrij beschikbaar zijn. Ook breidt de resistentie tegen het middel wat bij niet melkgevend vee wordt gebruikt (triclabendazol) uit. Preventieve maatregelen zijn nog beperkt voorhanden mede omdat de (besmettings)cyclus van de leverbot complex is; de bot is voor de voltooiing van de levenscyclus afhankelijk van een tussengastheer, het leverbotslakje (Galba truncatula), en van specifieke klimatologische omstandigheden.

De leverbotprevalentie bij melkvee is in Nederland onbekend. Wel laten jaarlijks ca. 3.000 melkveebedrijven hun tankmelk onderzoeken op leverbot. Hieruit blijkt geen toename in de leverbotprevalentie. In de ons omringende landen komt wel een toename uit de monitoring. Een deel van deze toename van (de mate van) besmette gebieden is te verklaren vanuit uit de veranderingen in het klimaat ( $\uparrow$ intensiteit extreme neerslag, $\uparrow$ temperatuur) en de vernatting van gebieden. Ook de manier waarop veehouders omgaan met infectierisico's (preventieve maatregelen) heeft invloed op de prevalentie.

\section{Doel}

Melkveehouders hebben behoefte aan kennis over preventieve maatregelen, alternatieve bestrijdingsmogelijkheden en het vermijden van resistentieontwikkeling tegen leverbotmiddelen op het bedrijf. Binnen dit project "Integrale diergezondheid: beheersing van leverbot" is een instrument ontwikkeld om de leverbotstatus op het melkveebedrijf te beoordelen, de risicofactoren in kaart te brengen en mogelijke preventieve maatregelen aan te geven. De belangrijkste handvatten uit een vergelijking van bedrijven op basis van dit instrument zijn: identificatie van leverbotgevoelige percelen, behandelen van positief jongvee op het juiste moment en toepassen van preventieve maatregelen.

Het leverbotinstrument is ingezet op 26 melkveebedrijven, zowel gangbaar als biologisch. Deze bedrijven zijn op basis van leverbotantistoffen in de tankmelk gevormd tot koppels van een negatief en een positief bedrijf uit hetzelfde gebied inclusief een differentiatie naar leverbotstatus in verschillende diergroepen. Een koppel 'buurbedrijven' zal een vergelijkbare kans lopen om met leverbot geïnfecteerd te raken omdat hun vee in gedeelde polders weiden met een sterk vergelijkbare habitat voor de leverbotslak. Verschillen in besmettingsniveaus op 'buurbedrijven' kunnen vervolgens veroorzaakt zijn door verschillen in management- en andere bedrijfsfactoren. Doel van dit onderzoek is om deze verschillen in kaart te brengen waarmee bedrijven infectieniveau's kunnen verlagen of een besmetting kunnen voorkomen.

Tijdens het project zijn diverse bijeenkomsten gehouden met veehouders. Hieruit zijn een aantal maatregelen naar voren gekomen die als perspectiefvol werden gezien om de leverbotcyclus te doorbreken. Op een drietal bedrijven is een maatregel geïmplementeerd om deze te toetsen. Op één bedrijf is het frezen van de greppels in de zomer toegepast en op twee van de drie bedrijven is een vorm van ontwijkend beweiden toegepast.

\section{Resultaten met behulp van leverbotinstrument}

De 26 bezochte bedrijven hadden gemiddeld 76 (32-193) melk- en kalfkoeien, 47 (0-145) stuks jongvee en een melkproductie van $7.360 \mathrm{~kg}(5.000-10.755 \mathrm{~kg})$ per jaar. Vanaf vier weken na opstallen is van, van tevoren geselecteerde groepen dieren, bloedonderzoek verricht om de leverbotstatus van het hele bedrijf vast te stellen. Hieruit kwam naar voren dat de uitslag van het eerdere tankmelkmonster niet altijd overeen kwam met de uitslag van het bloedonderzoek. Uiteindelijk zijn 15 bedrijven gematched waarbij het aantal koeien of jongvee en de melkgift niet verschilt tussen de leverbot positieve en negatieve bedrijven. Op vier van de zeven geïnfecteerde bedrijven vermoedde de veehouder geen leverbotinfectie.

Schade door leverbot kan bestaan uit een lagere melkopbrengst, minder en/of een vertraagde ontwikkeling van het jongvee, afgekeurde levers, verminderde vruchtbaarheid en weerstand. In dit 
onderzoek zijn geen verschillen gevonden in gemiddelde melkgift en het aantal benodigde inseminaties tussen positieve en negatieve bedrijven. Sterfte door leverbot komt eigenlijk niet voor bij runderen. De sterfte onder de melkkoeien op leverbot positieve bedrijven, waarschijnlijk door andere oorzaken, was wel hoger. De kalversterfte verschilde niet tussen de positieve en negatieve bedrijven. Runderen die besmet zijn met leverbot zijn in de regel gevoeliger voor andere (bacteriële) infecties zoals Salmonella vanwege een verminderde weerstand. In dit onderzoek kwam Salmonella echter niet vaker voor op bedrijven met leverbot. Wel komen er op de positieve bedrijven meer andere gezondheidsproblemen (o.a. klauwaandoeningen) voor.

Op een bedrijf kan de besmettingsstatus van de diergroepen verschillen door verschillen in beweiding. Bedrijven met leverbot positief jongvee hadden vaker een hoger percentage percelen waar regelmatig/langere tijd water in de greppels staat. In de gemiddelde kennis over leverbot (uitgedrukt in een score) zat geen verschil tussen de positieve en negatieve bedrijven. Wel waren op alle negatieve bedrijven de veehouders op de hoogte van de leverbotprognose in hun gebied en weten zij welke factoren een rol spelen bij de opbouw van een besmetting. De negatieve bedrijven in dit onderzoek passen meer preventieve maatregelen toe dan de positieve bedrijven. Dit zijn maatregelen zoals zomerstalvoedering, besmetting ontwijkend beweiden, weerstandsverhoging van het vee, aangepast slootkantbeheer en actieve ontwatering. De inzet van preventieve maatregelen kan verklaren waarom er bedrijven zijn die vrij zijn van leverbot ondanks dat zij zich bevinden in het leverbotgevoelige gebied.

Alleen jongvee kan men vrij behandelen voor leverbot. Goed behandelen van het jongvee is belangrijk. Dit om besmetting van (huiskavel)percelen in het voorjaar door inscharen van dieren in hun tweede of hogere weidegang die niet vrij zijn van leverbot te vermijden. In dit onderzoek bleek het geïnfecteerde jongvee verkeerd te worden behandeld. Daardoor dragen ze bij aan de infectieopbouw in het volgende weideseizoen. Ook bleek geen enkel bedrijf via mestonderzoek vast te stellen of de behandeling (nog) voldoende effectief was. Kortom individuele bedrijven hebben en houden slecht/geen zicht op de resistentieontwikkeling.

Tijdens het project is ervaring op gedaan met het vaststellen van de leverbotgevoeligheid van percelen en het vaststellen van een besmetting van de percelen en infectie van het vee. De leverbotslakgevoeligheid van een perceel kan vastgesteld worden door het bekijken van de biotoop en indicatorplanten en middels karteren (het vangen en zo aantonen van de aanwezigheid van de leverbotslak). Om een leverbotbesmetting van het perceel vast te stellen moet vervolgens nagegaan worden of de leverbotslak geïnfecteerd is met de trilhaarlarve of dat afzetting van cercaria heeft plaatsgevonden. Het identificeren van leverbotslakgevoelige percelen middels karteren is niet makkelijk. Succes is er vaak alleen onder specifieke omstandigheden waaronder de temperatuur $\left(10^{\circ} \mathrm{C}-25^{\circ} \mathrm{C}\right)$ en voldoende vocht. Het aantal slakjes kan ook zeer gering zijn, waardoor de kans om ze te vinden vrij laag is.

Besmetting in het dier kan opgespoord worden middels melk- en bloedonderzoek vanaf vier weken na het oplopen van een besmetting of via mestmonsters (eitelling) vanaf 12 weken na het oplopen van een besmetting. Men kan de tankmelk gecombineerd laten testen op maagdarmworm- en leverbotinfecties. Dit gebeurt voor leverbot vaak te vroeg in het najaar (september/oktober/november), waardoor er nogal eens onterecht negatieve uitslagen gegeven worden. Dit vormt een belangrijke verklaring voor de onverwacht positieve uitslagen bij de vorming van de matches. De tankmelkuitslag zegt niets over de andere aanwezige groepen dieren op het bedrijf en een positieve uitslag laat zich voorts niet altijd eenvoudig differentiëren naar de besmette groep runderen. Daarvoor is individuele melk- of bloedbemonstering nodig. De groepsinformatie op basis van bloedonderzoek naar leverbotantistoffen (positief en negatief) kan, in combinatie met beweidingsinformatie, percelen aanmerken als leverbotgevoelig of leverbotongevoelig. Uitslagen van onderzoek naar leverbotantistoffen kan ook de introductieroute van een leverbotbesmetting op het bedrijf blootleggen. Het testen op leverbotantistoffen op groepsniveau draagt zodoende bij aan een meer gerichte aanpak van de leverbotproblematiek en het formuleren van effectieve maatregelen ter preventie of minimalisering van leverbot op het bedrijf.

Op het slachthuis kan de lever beoordeeld worden op kenmerken van met leverbot geïnfecteerde levers zoals vergrote galgangen, fibrose en/of aanwezigheid van botten. Helaas wordt vaak niet de reden van afkeur gespecificeerd en doorgegeven aan de veehouder. Voor alle afkeur indicaties geldt dat de infectie meer dan een jaar oud kan zijn. Een afkeuring duidt niet altijd op een actuele infectie tenzij het dieren betreft met maximaal één weidegang. Alleen in dat laatste geval vormt afkeuring van de lever een reden om na te gaan of behandeling van de nog aanwezige weidegenoten nodig is. 


\section{Uitgeprobeerde preventieve maatregelen}

Zomerfrezen is een relatief eenvoudige en praktische maatregel om de leverbotslakkenpopulatie te decimeren. Hiermee wordt een enorme afzetting van besmetting in het najaar voorkomen. Het is vooral een kwestie van toepassen op het juiste moment: zo kort mogelijk na maaien of weiden én bij verwachte droge dagen. Dit maximaliseert het effect. In dit (kleine) onderzoek bedroeg het procentuele verschil in het aantal besmette kalveren $(2 \times 5$ kalveren) geweid op de gefreesde en niet gefreesde delen van twee percelen $60 \%$. Deze kalveren waren geweid van begin augustus tot half oktober. Voor omweiden, half september, was op het gefreesde deel zelfs geen enkel kalf besmet. Terwijl op het eerste, niet gefreesde deel van het perceel toen reeds drie van de vijf kalveren besmet zijn geraakt met leverbot. Dit duidt op een zichtbaar positief effect van zomerfrezen van de greppels op het besmettingsrisico, zowel later als minder. Afhankelijk van het seizoen kan al in juni met zomerfrezen worden gestart. Hoe eerder in het weideseizoen men ermee begint hoe kleiner de kans dat door natte zomers/vroege herfst percelen niet gefreesd kunnen worden voordat de herfst begint. In deze situatie heeft frezen begin september ook nog een reducerend effect gesorteerd ondanks minder gunstige weersomstandigheden voor zomerfrezen.

Ontwijkend beweiden kan door het uitrasteren van waterlichamen (zoals sloten, poelen of greppels) die langdurig vol staan met water en drassige delen én door het ontwijken van leverbotgevoelige en/of besmette percelen (vastgesteld middels karteren). Hiermee wordt de opname van cercaria door het vee voorkomen. Het ontwijkend beweiden door middel van uitrasteren lijkt een effectieve maatregel om het aantal besmette dieren in de koppel, en waarschijnlijk ook de mate van infectie, met leverbot aanzienlijk te verminderen. Zowel in 2014 als 2015 was slechts $20 \%$ van de melkkoeien op het testbedrijf geweid op de leverbotgevoelige huiskavel positief. Terwijl in de vertreksituatie $100 \%$ van de melkkoeien positief was.

De inzet van loopeenden op besmette percelen om de tussengastheer van leverbot weg te vangen en hiermee de cyclus te doorbreken is praktisch lastig gebleken waardoor de effectiviteit van de loopeenden niet vastgesteld kon worden. Het effect van drainage op de leverbotgevoeligheid van de percelen is (nog) niet duidelijk en ook effectieve maatregelen om de weerstand tegen leverbotziekte te verhogen (zoals een voederadditief of vaccin) ontbreken nog.

\section{Aanbevelingen}

Mede door de beperkte behandelingsmogelijkheden is het van belang om inzicht te hebben in de leverbotstatus van uw bedrijf en met behulp van preventieve maatregelen infecties te voorkomen. Hiertoe doen wij de volgende aanbevelingen;

1. Vul, samen met uw dierenarts of andere specialist, het leverbotinstrument in om van groepen dieren (kalveren, pinken, drachtige vaarzen, droge koeien, nieuwmelkte- en oudmelkte koeien, schapen en lammeren) de leverbotstatus vast te stellen, de risicofactoren voor uw bedrijf vast te stellen en om mogelijke preventieve maatregelen te identificeren. Stel aan de hand hiervan een eigen plan van aanpak op om leverbotbesmetting te voorkomen op uw bedrijf

2. Bepaal de leverbotgevoeligheid van uw percelen, door te inventariseren of er waterlichamen (als greppels, drassige slootkanten, langdurige pootgaten ( $>$ jaar), poeltjes in/op percelen of indicatorplanten aanwezig zijn

3. Bepaal (of laat bepalen) of een perceel besmet is. Dit kan door leverbotslakjes te zoeken en te controleren op de aanwezigheid van de leverbottrilhaarlarven (pletten en onder de microscoop bekijken). Of ga na of er afzetting van cercaria heeft plaatsgevonden op het perceel (door een cellofaantje in waterlichaam te plaatsen)

4. Bepaal de leverbotstatus van uw dieren, door vanaf 4 weken na opstallen melk of bloed te laten controleren op leverbotantistoffen. Vanaf 12 weken na opstallen kunt u een mengmonster mest van 5 dieren op de aanwezigheid van leverboteieren laten controleren

5. Vraag om een terugkoppeling van de leverbeoordeling in het slachthuis. Let er wel op dat een afgekeurde lever het gevolg kan zijn van een infectie in een ander jaar. Stem de behandelnoodzaak van weidegenoten daarom af op de actualiteit van de zo gevonden besmetting.

6. Behandel besmet jongvee, vanaf 2 weken na opstallen, met een middel met als werkzame stof triclabendazol, mits hier geen resistentie tegen bestaat. Dit geldt ook voor geïnfecteerd jongvee dat terugkomt van de opfok. Behandel bij een flinke infectie, in overleg met de dierenarts en binnen de cascaderegeling, het gehele melkkoppel vanaf 2 weken na opstallen met een middel met als werkzame stof triclabendazol. Triclabendazol doodt alle leverbotstadia vanaf twee weken na opname door het dier. Bij behandelen direct bij opstallen is de kans groot dat men infecties 
opgelopen in de twee weken voorafgaand aan opstallen laat zitten. Controleer via mestonderzoek op 10 dagen na behandelen of de behandeling effect heeft gehad

7. Voorkom een leverbotbesmetting, door waterlichamen uit te rasteren of percelen met waterlichamen in de risicomaanden te ontwijken. Frees de greppels bij drogend weer (zomer). Stal uw dieren in het najaar op voordat de afzetting van besmetting op het gras (cercaria) heeft plaatsgevonden. En gebruik bij (zomer)stalvoedering alleen veilig gras (dus geen gras van leverbot besmette percelen of gras naast waterlichamen). Voorkom insleep van leverbot op de eigen bedrijfspercelen via aangevoerde dieren, via terugkerend vee dat elders is geweid en via het inscharen van vee van derden. Pas de juiste quarantainemaatregelen toe als aangevoerd, terugkerend of ingeschaard vee (mogelijk) is geweid op leverbotgevoelige percelen 


\section{Summary}

The analysis of risk factors and prevalence of liver fluke took place in the Netherlands, Denmark, Germany, and Lithuania. This is the report on the findings in the Netherlands. In the Netherlands, the liver fluke surveys are performed on 26 farms; 13 pairs of neighbouring positive and negative cattle farms have been identified based on liver fluke antibodies in bulk milk samples. It was stated that the outcomes of blood antibodies were not in line with bulk milk samples. Using bulk milk samples only to identify liver fluke farms will underestimate the prevalence of liver fluke. Blood sampling on all present on farm groups of animals is necessary for a good estimate of the prevalence of liver fluke. Therefore the risk factor analysis is performed with the remaining 8 pairs of neighbouring positive and negative cattle farms.

(Economic) losses from liver fluke may consist of a lower milk yield, less and / or a delayed development of young stock, rejected livers, reduced fertility and resistance. In this research, no differences were found in average milk yield and the number required inseminations between positive and negative companies. However, there are more health problems (such as claw diseases) on the positive farms.

Average knowledge about liver fluke (expressed in a score) showed no difference between positive and negative farms. However, at all negative farms, the farmers were aware of the liver fluke prognosis in their area and the risk factors. They also apply more preventative measures than positive farms, such as summer stable feeding, avoiding contaminated plots, increasing resistance of livestock, adapted ditch management and active dewatering. In this study the infected young stock was found to be treated incorrectly. As a result, they contribute to the infection build-up in the following grassland season.

In short, clearly identified risk factors for liver fluke are wrong treatment of cattle and sheep including not being allowed to treat lactating animals grazing on parcels at risk. Preventative measures such as summer feeding and drainage provides a lower risk on liver fluke. A remarkable finding is that the salmonellosis prevalence is not higher on positive liver fluke farms.

Promising preventative measures have been investigated, of which summer milling of trenches in order to decimate the Galba truncatula population and evasive grazing had both a positive influence on preventing/lowering the risk of liver fluke infection. 
14 | Wageningen Livestock Research, Louis Bolk Instituut, rapport 1029 


\section{$1 \quad$ Inleiding}

Infecties met leverbot en/of maagdarmwormen en bestrijding en/of behandeling van deze infecties lijken in toenemende mate een knelpunt te worden in de diergezondheid van grazende (of vers gras gevoerde) herkauwers in de ons omringende landen. In de periode van 2007 tot en met 2014 zijn in Nederland 10.099 leverbotinfecties door de GD aangetoond op totaal 2.490 bedrijven (zie figuur 1 ). De daadwerkelijke leverbotprevalentie wordt in Nederland niet gemonitord. Probleem bij vooral de lacterende dieren is dat zij niet meer mogen worden behandeld tegen leverbot, omdat er geen geregistreerde middelen voor melkgevende runderen voorhanden zijn. De enige behandelmogelijkheid is om gebruik te maken van de cascaderegeling. De besmettingscyclus van leverbot is complex, de mogelijkheden ten aanzien van de inzet van geneesmiddelen zijn beperkt en de resistentie tegen triclabendazol breidt zich steeds verder uit (GD; Kelley et al., 2016).

Leverbot wordt wereldwijd gezien als een zoönose (Fairweather, 2011; Mas-Coma et al., 2009). Mensen kunnen geïnfecteerd raken via de opname van besmet water of waterplanten en soms door consumptie van onvoldoende verhitte leverproducten (Mas-Coma et al., 2009). In Nederland is volgens het RIVM waarschijnlijk nog nooit iemand geïnfecteerd geraakt (www.RIVM.nl). Echter, Winkelhagen et al. (2012) maken melding van een leverbotinfectie bij een Nederlandse schapenhouder in 2007.

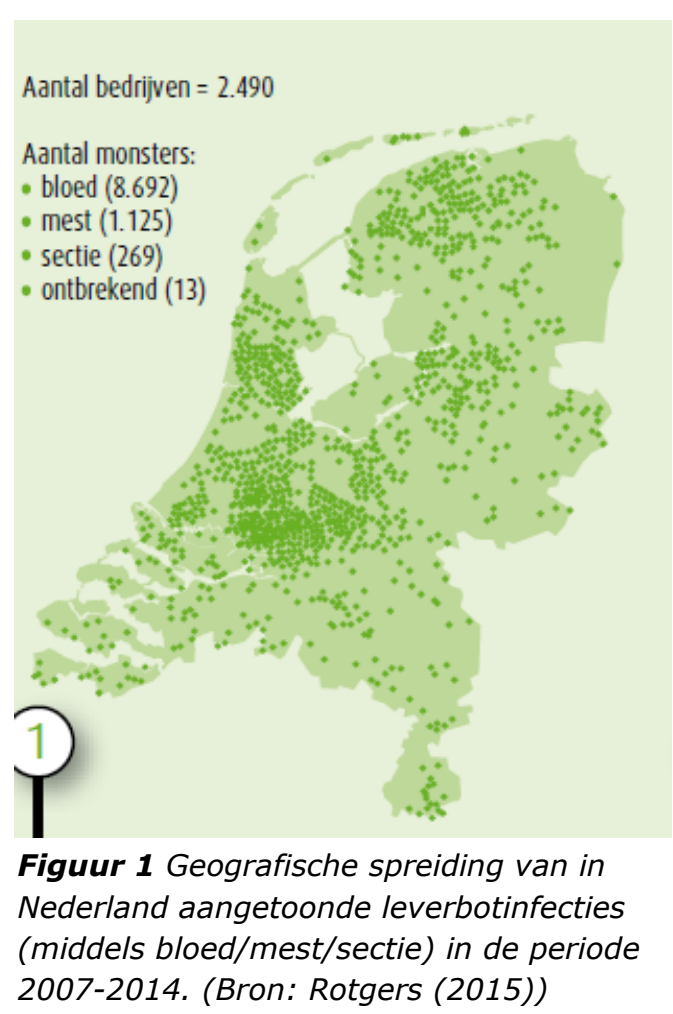

Leverbotinfectie is een veel voorkomende infectie in de Nederlandse rundveehouderij die gepaard kan gaan met aanzienlijke economische gevolgen. De GD schat de kosten van een leverbotinfectie op een bedrijf met 60 melkkoeien met weidegang rond de 4000-6500 euro per jaar (GD, z.j.-b). De kosten van een leverbotinfectie in Zwitserland zijn door Schweizer et al. (2005) lager becijferd op gemiddeld 615 tot 2.897 euro per bedrijf. Schade bij melkvee wordt vooral veroorzaakt door de beschadigingen die de leverbotten aanrichten in de lever (littekenweefsel of fibrose). Het aantal leverbotten bepaalt de schade maar ook al kan de schade aanzienlijk zijn, zelden gaat dit gepaard met sterfte bij het rund (Borgsteede, 2011). Runderen vormen bij een infectie antistoffen tegen leverbot. Een leverbotinfectie triggert het immuunsysteem van de koe. Of koeien weerstand opbouwen tegen leverbot waardoor een herhaalde infectie minder kans heeft om te overleven en/of schade aan te brengen is onduidelijk. In een Ierse studie is aangetoond dat er wel genetische variatie in gevoeligheid voor leverbot bestaat tussen koeien, waardoor het mogelijk lijkt om op meer resistente koeien te fokken (Twomey et al. (2016).

De beschadigingen in de lever kunnen leiden tot een verminderde groei bij jongvee. Ernstige infecties leiden tot een lager karkasgewicht, lagere vleeskwaliteit en minder lichaamsvet bij jongvee en melkvee (Sanchez-Vazquez \& Lewis, 2013). De verminderde groei is voornamelijk te zien bij vee jonger dan twee jaar (Kaplan, 2001). Indien een kalf geïnfecteerd is wordt de opname van nutriënten uit gras verminderd door suboptimaal functioneren van de lever. Op 640 dagen leeftijd is het lichaamsgewicht gemiddeld 15 kilo minder bij geïnfecteerde dieren (persoonlijke mededeling in Skuce and Zadoks (2013). De schattingen over dalende melkopbrengsten bij dieren lopen uiteen van $1-1,5$ (Dobbs, 2013), 2 (Mezo et al., 2011) tot soms 3 (Howell et al., 2015) kilogram meetmelk per dag bij met leverbot besmette melkkoeien. De mate van verminderde melkproductie loopt op met een toename van het aantal botten die is af te lezen aan het aantal antilichamen in het bloed (Boray, 2015; Howell et al., 2015). Daarnaast kan de infectie gevolgen hebben voor de fertiliteit; bij 
volwassen koeien kan de tussenkalftijd toenemen met 5 (Armstrong, 2014), 13 (Schweizer et al., 2005) tot 20 dagen (Dobbs, 2014) en bij geïnfecteerde vaarzen kan de eerste tochtigheid tot 39 dagen later zijn dan bij niet geïnfecteerde dieren (Kaplan, 2001). Echter, Howell et al. (2015) vonden in een studie op hoog productieve Engelse bedrijven, waarbij in de analyse rekening werd gehouden met het productie niveau, geen verband tussen een leverbotinfectie en fertiliteit. Sommige studies wijzen uit dat het vetpercentage in de melk verlaagd is. Uit onderzoek vanuit België is gebleken dat het gemiddelde vetpercentage met $0.06 \%$ daalt (Armstrong, 2014), wat ook werd gevonden in een aantal onderzoeken die Howell et al. (2015) aanhalen. Echter, in dezelfde review staan ook referenties die geen verlaging hebben gevonden. Het percentage eiwit blijkt niet te dalen als gevolg van een infectie (Armstrong, 2014). Als laatste is er nog een verband aangetoond tussen de gevoeligheid voor een Salmonella infectie en Mycobacterium bovis en de aanwezigheid van leverbot (Dalton et al., 2013; Naranjo Lucena et al., 2017; Vaessen et al., 1998). Salmonella- en leverbotbesmettingen komen vaak op dezelfde rundveebedrijven en bij dezelfde runderen voor (GD, z.j.-a). Volgens de

Gezondheidsdienst voor Dieren zijn hiervoor twee mogelijke verklaringen. Ten eerste is de ligging van het rundveebedrijf in een waterrijk gebied een risicofactor voor beide infecties. Ten tweede verhoogt een leverbotinfectie de gevoeligheid van runderen voor een Salmonella-infectie, waardoor verschijnselen van Salmonellose ernstiger worden en runderen langer besmettelijk blijven (GD, z.j.-a). Dalton et al. (2013) geven ook als reden dat de leverbot een immunosuppressief effect heeft. De parasieten vernietigen leverweefsel en veroorzaken verdikkingen van de galgang. Deze raakt daardoor geblokkeerd en geïnfecteerd wat een negatief effect heeft op het functioneren van de lever en de afgifte van gal. De grootste schade wordt veroorzaakt door de migratie van de onvolwassen leverbotten van de darmen naar de lever en de galgang (Ferreira, 2012). Het is aannemelijk dat de aanpak van leverbot op een bedrijf op langere termijn ook een gunstig effect heeft op de beheersing van Salmonellose (GD, z.j.-a).

Met leverbot geïnfecteerde herkauwers scheiden leverboteieren uit in de mest, die, als de dieren geweid worden, op het land terecht komen. Uit deze eieren ontwikkelen zich trilhaarlarven die de tussengastheer, het leverbotslakje (Galba truncatula), besmet, wat de piek verklaart in het aantal met trilhaarlarven besmette slakjes tussen mei en juni als het vee in het voorjaar het land is opgegaan. De leverbotslak is volwassen tussen juli en september. De larven ontwikkelen zich in de slak in ongeveer 11 weken. Daarna komen de larven (cercaria) uit de slak en zetten zich op het gras vast als infectieuze cysten (ingekapselde metacercaria) rond de maanden september tot november. Dit verklaart de hoge infectiedruk van leverbot in het najaar (Charlier et al., 2014; Hourdin et al., 2006). De cysten worden weer opgenomen door het vee, waarna ze zich als jonge leverbotten door de dunne darmwand vreten en naar de lever migreren. In de lever groeien ze uit tot volwassen botten en scheiden daar gedurende het gehele jaar eieren uit. De leverboteieren, de metacercaria en de besmette leverbotslakjes kunnen de winter in Nederland overleven waardoor een infectie van het vee vroeg in het graasseizoen op kan treden (Gaasenbeek et al., 1992).

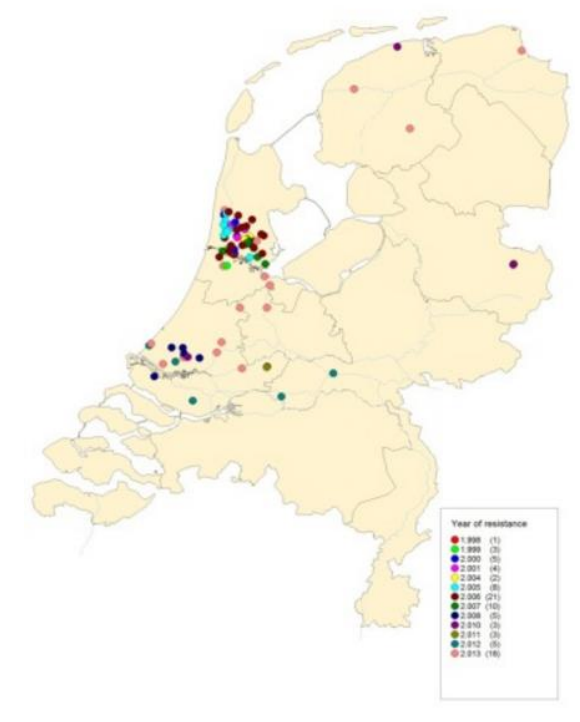

Figuur 2 Uitbreiding van de leverbotresistentie voor triclabendazol in Nederland op via de $G D$ gecontroleerde bedrijven van 1998 tot en met 2013 (GD) 
De slak heeft een cyclus die in meerdere landen is onderzocht en overal vrijwel gelijk is. Vanaf het begin van de maand juli is er een piek in het aantal volwassen leverbotslakken die na de maand juli afloopt tot eind september. Begin oktober tot eind december kan er opnieuw een piek voorkomen indien de weersomstandigheden zich daarvoor lenen (Charlier et al., 2014; Hourdin et al., 2006).

De verspreiding van leverbotinfecties is gelinkt aan omgevingsfactoren waaronder vooral de aanwezigheid van water. De tussengastheer, het leverbotslakje (in Europa vooral de Galba truncatula), heeft water nodig om te groeien en te reproduceren. Voor de vrij levende vormen van de leverbot geldt hetzelfde (Caron et al., 2007; Fairweather, 2011; Mas-Coma et al., 2009; Selemetas et al., 2015a). Onderzoek toont aan dat de meeste slakken worden gevonden in greppels en licht moerasachtige grond (Charlier et al., 2014). Wel is het belangrijk dat het stilstaand water is dat wordt opgewarmd door de zon. Hierdoor groeien de algen in het water goed wat het voedsel van de slak is. Voor de algengroei is zuurstofrijk water nodig waardoor het belangrijk is dat er af en toe water wordt ververst, het liefst met een regenbui (Charlier et al., 2014). Het slakje heeft een voorkeur voor een $\mathrm{pH}$ waarde van het water van hoger dan 5 (Rondelaud et al., 2011). Naast vocht en algen is de temperatuur ook een belangrijke factor voor de voortgang van de cyclus van de leverbot(slak). De leverbotslakken kunnen overleven en zich voortplanten als de temperatuur tussen de 10 en $25^{\circ} \mathrm{C}$ is (Fox et al., 2011). De ideale temperatuur waarbij de slak zeer actief is en zich zeer snel voortplant is tussen 22 en $25^{\circ} \mathrm{C}$. Boven een temperatuur van $25^{\circ} \mathrm{C}$ is het percentage slakken en cysten dat kan overleven verwaarloosbaar klein, bijna nul (Rapsch et al., 2008). Trouve et al. (2005) geven aan dat in het algemeen de leverbotslakjes dichtheid waarschijnlijk niet erg hoog ligt.

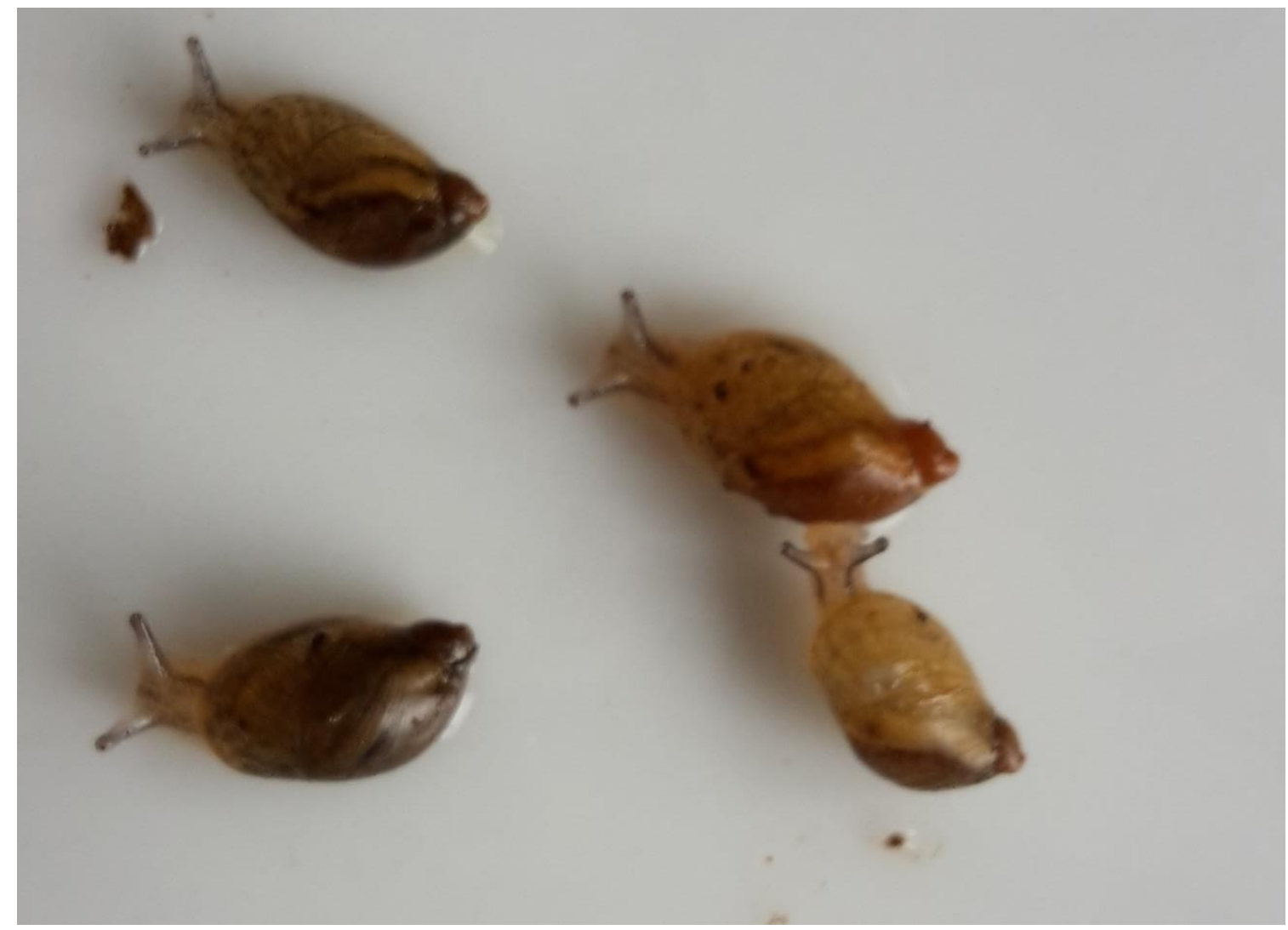

Figuur 3 Leverbotslakjes (Galba truncatula)

De optimale temperatuur voor de trilhaarlarven ligt rond de $20^{\circ} \mathrm{C}$ (Boray, 2015; Charlier et al., 2014; Rapsch et al., 2008). Maar Rondelaud et al. (2013) geeft aan dat een periode met lagere temperatuur $\left(12^{\circ} \mathrm{C}\right)$ juist het uittreden (shedden) van de cercaria stimuleert.

Van de deelnemende bedrijven aan het GD-tankmelkonderzoek van 2011 tot 2016 (2000-2350 bedrijven) waren respectievelijk $26,6 \%, 27,5 \%, 23,8 \%, 25,8 \%, 21,3 \%$ en $26,1 \%$ positief op leverbot. In deze selecte steekproef zien we geen toename in leverbotinfectie. Het aantal geïnfecteerde melkveebedrijven lijkt in andere landen toe te nemen (Fairweather, 2011; Fitzpatrick, 2013; KnubbenSchweizer \& Torgerson, 2015; Olsen et al., 2015; Selemetas et al., 2015b). De prevalentie van leverbot in Nederland wordt niet gemonitord (buiten de gegevens die zijn verkregen van bedrijven die deelnamen aan GD tankmelkonderzoek) waardoor onbekend is of in Nederland eveneens sprake is van een toename in leverbot. Een deel van de EU-toename van (de mate van) besmette gebieden kan 
verklaard worden uit de veranderingen in het klimaat (intensiteit extreme neerslag, verhoging van de temperatuur) en de vernatting van gebieden ten behoeve van de natuur en weidevogels (Fox et al., 2015; Fox et al., 2011). Daarnaast kan de manier waarop veehouders omgaan met infectierisico's invloed hebben op de prevalentie. Zo is insleep van infectie mogelijk via aangekocht geïnfecteerd vee en levert het weiden in natte gebieden een hoger risico op (Olsen et al., 2015).

In onder andere Zwitserland, Engeland, België en Nederland zijn modellen ontwikkeld om het infectierisico geografisch in kaart te brengen (Bennema et al., 2011; Ducheyne et al., 2015; Fox et al., 2011; Kuerpick et al., 2013; McCann et al., 2010; Rapsch et al., 2008). In Nederland heeft de Gezondheidsdienst voor Dieren, samen met LTO en NZO, de leverbotalert ontwikkeld. Hiermee wordt een prognose afgegeven voor het risico op een leverbotbesmetting in Nederland, op basis van analyse van grondsoorten, slakkentellingen, klimatologische omstandigheden en bodemvochtgegevens.

In 2014 hebben Wageningen Livestock Research en het Louis Bolk Instituut de beschikbare kennis over leverbot op een rij gezet: de leverbotcyclus en mogelijke maatregelen om deze cyclus te doorbreken (Neijenhuis et al., 2014). Hiermee is een eerste versie van een instrument ontwikkeld waarmee de leverbotstatus op individuele bedrijven kan worden beoordeeld, de risicofactoren in kaart worden gebracht en mogelijke preventieve maatregelen aan worden gegeven. Na 2014 is het instrument verder aangescherpt. Deze tweede versie van het instrument is in 2015 en 2016 gebruikt om na te gaan wat mogelijke maatregelen zijn om de leverbotsituatie op (individuele)

melkveebedrijven te verbeteren. Maatregelen ter voorkoming van een leverbotinfectie zijn te verdelen in het 'ingrijpen' in de habitat van de slak, het verwijderen van de slak, het voorkomen van 'contact' met de slak en het voorkomen van insleep van de besmetting.

\section{Leeswijzer}

In hoofdstuk 2 van dit rapport wordt de tweede versie van het instrument beschreven en met behulp van het instrument is nagegaan waar de verschillen zitten tussen bedrijven, in eenzelfde gebied, die wel of niet met leverbot besmet zijn (hoofdstuk 4).

In hoofdstuk 3 wordt vanuit de opgedane kennis in dit project ingegaan op de manier van vaststellen van de leverbotinfectiestatus.

In hoofdstuk 5 wordt beschreven hoe een drietal maatregelen om infecties met leverbot te minimaliseren of te voorkomen (ontwijkend beweiden, zomers greppels frezen en inzet loopeenden) op praktijkbedrijven is uitgeprobeerd met als doel ervaring op te doen met deze maatregelen en de praktische implementatie alsmede het bepalen van het effect van deze maatregelen.

In hoofdstuk 6 wordt de verkregen kennis samengevat waarmee de kans op leverbotinfecties kan worden verkleind. In hoofdstuk 7 volgt de discussie en conclusie van de resultaten van dit project en aansluitend aandachtspunten en praktische aanbevelingen. 


\section{Leverbotinstrument (versie 2)}

Het leverbotinstrument is een tool waarmee men de leverbotstatus op het bedrijf beoordeelt, de risicofactoren in kaart brengt en mogelijke preventieve maatregelen identificeert. Dit vanuit het gegeven dat 1 . leverbotinfecties in toenemende mate een knelpunt vormen, 2 . er een groeiende behoefte onder melkveehouders is aan kennis over de leverbotsituatie op hun bedrijf en 3 . de behoefte aan handelingsperspectief om de individuele situatie te verbeteren. Veehouders hebben behoefte aan kennis en mogelijkheden ter preventie van leverbotinfecties, en aan alternatieven voor een effectieve bestrijding van de leverbot en het voorkomen van resistentie tegen leverbotmiddelen. In 2014 heeft dit project het eerste concept leverbotinstrument beschreven (Neijenhuis et al., 2014). In 2015 en 2016 is het concept leverbotinstrument verder ontwikkeld en getest op 26 melkveebedrijven. Het instrument is in die periode verder aangescherpt en er is een scoresysteem aan gekoppeld. Deze versie van het instrument, compleet met de kwalitatieve beoordeling van het individuele bedrijf, vormt het uitgangspunt voor een gefundeerde advisering op verbeterpunten en maatregelen voor de aanpak van de leverbotproblematiek op dat bedrijf. Het uiteindelijke doel van het instrument is dat veehouders inzicht en handelingsperspectief krijgen ten aanzien van de leverbotsituatie op hun bedrijf.

\subsection{Leverbotinstrument en scoresysteem}

In de ontwikkeling van het leverbotinstrument van concept (zie Neijenhuis et al. (2014)) naar bruikbare tool zijn scores gekoppeld aan de antwoorden. Het instrument (bijlage 1) is verdeeld in acht onderdelen (tabel 1). Een aantal onderdelen betreft parameters die op zichzelf niet direct een risicofactor zijn voor een leverbotbesmetting, maar wel indicatief kunnen zijn voor een gezondheidsprobleem als leverbot. Deze onderdelen zijn in tabel 1 onder focus als 'prestatieindicatoren' benoemd. Andere onderdelen gaan in op de geïdentificeerde (vermeende) risicofactoren op een bedrijf en zijn in tabel 1 onder focus als 'risicofactoren' benoemd. In tabel 1 staan de minimale en maximale score en de interpretatie per onderdeel weergegeven. Uit de scores op de verschillende onderdelen komt naar voren waar de knelpunten liggen op het betreffende bedrijf. Op basis hiervan kan men verbeterplannen formuleren en advies krijgen over te nemen maatregelen.

Tabel 1 Onderdelen van het ontwikkelde leverbotinstrument

\begin{tabular}{|c|c|c|c|c|}
\hline & onderdeel & focus & Score & interpretatie \\
\hline $\mathrm{I}$ & Bedrijfsparameters & Prestatie-indicatoren & $0-23$ & risico op leverbot \\
\hline II & Gezondheid & Prestatie-indicatoren & $0-11$ & risico op leverbot \\
\hline III & Vaststelling leverbot & Prestatie-indicatoren & $0-11$ & kans op actuele besmetting met leverbot \\
\hline IV & $\begin{array}{l}\text { Aanvoer en } \\
\text { quarantaine }\end{array}$ & Risicofactoren & $0-16$ & risico op insleep van leverbot \\
\hline V & $\begin{array}{l}\text { Behandeling en } \\
\text { resistentie }\end{array}$ & Risicofactoren & $0-28$ & $\begin{array}{l}\text { Rapportcijfer voor fout behandelen en kans op } \\
\text { resistentie }\end{array}$ \\
\hline VI & $\begin{array}{l}\text { Leverbotgevoelige } \\
\text { percelen }\end{array}$ & Risicofactoren & $0-16$ & risico op leverbot \\
\hline VII & $\begin{array}{l}\text { Overige preventieve } \\
\text { maatregelen }\end{array}$ & Risicofactoren & $0-14$ & rapportcijfer voor preventieve maatregelen \\
\hline VIII & Kennis veehouder & Risicofactoren & $0-11$ & rapportcijfer voor kennis over leverbot \\
\hline
\end{tabular}

Onderdeel I betreft algemene bedrijfsparameters. Deze parameters geven een indruk van de bedrijfssituatie en hoeven niet direct specifiek verband te houden met al dan niet een infectie met leverbot. Het zijn indicatieve parameters die ook meegewogen worden in het scoresysteem. De totaalscore van dit onderdeel weerspiegelt het risico op leverbot.

Onderdeel II betreft de algemene diergezondheid op het bedrijf. Er wordt in dit onderdeel een aantal gezondheidsaandachtspunten bij melkvee nagelopen die mogelijk duiden op een leverbotinfectie. De score op dit onderdeel weerspiegelt eveneens het risico op leverbot.

Onderdeel III gaat in op de manier waarop de veehouder een leverbotinfectie vaststelt. Het betreft zowel objectieve kenmerken, zoals welke diagnostische testen die een veehouder laat uitvoeren, als meer subjectieve waarnemingen aan het dier / koppel door de veehouder zelf. De score is een maat 
voor de kans op een actuele besmetting met leverbot. Als er sprake is van een vastgestelde besmetting, dan vervalt het nut van het maken van een inschatting van de kans op een besmetting en kan men de betreffende vragen desgewenst laten vervallen. Evengoed dragen ze wel bij aan de beoordeling van het kennisniveau van de veehouder door de expert.

Onderdeel IV gaat na of een bedrijf dieren aanvoert en of het bedrijf hierbij rekening houdt met een mogelijke leverbotbesmetting. Dit onderdeel beoordeelt het toepassen van quarantaine maatregelen en geeft met de score een inschatting van het risico op insleep van leverbot via aanvoer van runderen en/of schapen.

Onderdeel V inventariseert of, hoe en waarmee een veehouder tegen leverbot behandelt.

Verschillende diercategorieën en diersoorten worden (apart) bekeken. Er wordt ook gevraagd hoe een veehouder het diergewicht bepaald, hoe hij doseert en of er op het bedrijf resistentie tegen leverbotmiddelen is aangetoond. De score is een omgekeerd rapportcijfer voor fout behandelen tegen leverbot en (daardoor) de kans op resistentie tegen leverbot. Hoe meer fouten men maakt, hoe hoger de score en hoe groter de kans op resistentie.

Onderdeel VI bevraagt in welke mate er sprake is van leverbotgevoelige percelen op een bedrijf en welke diercategorieën men waar weidt. De vragen zijn gericht op de ontwatering van de percelen en potentiële plaatsen die als habitat fungeren voor de leverbotslak als tussengastheer. De score benoemt het risico op leverbot.

Onderdeel VII maakt een inventarisatie van welke preventieve maatregelen de veehouder bewust of onbewust toepast om leverbotbesmettingen te voorkomen of te beperken. De score is het rapportcijfer voor toepassing van preventieve maatregelen.

Onderdeel VIII omvat vragen over de praktische leverbotkennis van de veehouder. De expert beoordeelt zijn kennis aan de hand van de ingevulde vragenlijst en het interview tijdens het bedrijfsbezoek. Op hoofdlijnen vat dit onderdeel samen in hoeverre de veehouder inzicht heeft in de leverbotproblematiek, de levenscyclus van leverbot, behandelingen en maatregelen én inzicht heeft in de risico's van aanvoer en verkeerd behandelen. De score is een rapportcijfer voor de kennis over leverbot.

\subsubsection{Vragenlijst en bedrijfsbezoek}

De deelnemende veehouders krijgen voorafgaand aan het bedrijfsbezoek een vragenlijst opgestuurd, die de verschillende onderdelen van het leverbotinstrument betreft. In een gesprek gaat een expert met de veehouder ontbrekende antwoorden, tegenstrijdigheden, opvallende afwijkingen en in het oog springende details bespreken. Dit bevordert een betrouwbare interpretatie van de leverbotproblematiek op het bedrijf en stimuleert een goede advisering op verbeterkansen en potentiële maatregelen.

\subsubsection{Monitoring van leverbotantistoffen}

Het leverbotinstrument helpt de groepen dieren (kalveren, pinken, drachtige vaarzen, droge koeien, nieuwmelkte- en oudmelkte koeien, schapen en lammeren) die risico lopen op een leverbotinfectie te identificeren. Bloed- en tankmelkbemonstering op leverbotantistoffen kan een goede indruk van de leverbotstatus op een bedrijf geven, mits de monsters op het juiste moment na eventuele besmetting zijn genomen (zie hoofdstuk 3). Onderlinge verschillen in infectie tussen de aanwezige groepen zijn inzichtelijk te maken met melk- of bloedbemonstering van enkele individuele dieren per groep. Die groepsinformatie (positief en negatief) kan, in combinatie met beweidingsinformatie, helpen percelen aan te merken als leverbotgevoelig of leverbotongevoelig. De uitslagen van het onderzoek naar leverbotantistoffen kan ook de introductieroute van een leverbotbesmetting op het bedrijf blootleggen. Het testen op leverbotantistoffen op groepsniveau draagt zodoende bij aan een meer gerichte aanpak van de leverbotproblematiek en het formuleren van effectieve maatregelen ter preventie of minimalisering van leverbot op het bedrijf. 


\section{$3 \quad$ Methoden vaststellen besmetting}

Gedurende de looptijd van dit project is ervaring opgedaan met het vaststellen van de besmetting van percelen en dieren. Uit de opgedane ervaring komt een aantal aandachtspunten naar voren over de verschillende manieren waarmee een leverbotbesmetting is vast te stellen.

\subsection{Aanwezigheid van leverbotslak, trilhaarlarve en cercaria}

Voor het opdoen van een leverbotbesmetting is het noodzakelijk dat op het perceel (of het gemaaide gras) besmette leverbotslakjes (Galba truncatula) aanwezig zijn (zie ook hoofdstuk 0). Er zijn twee methoden om de leverbotslakgevoeligheid van een perceel vast te stellen; middels het bekijken van de biotoop en indicatorplanten en middels karteren (het vangen van en zo aantonen van de aanwezigheid van de leverbotslak). Om leverbotbesmetting van het perceel vast te stellen moet vervolgens nagegaan worden of de leverbotslak geïnfecteerd is met de trilhaarlarve of dat afzetting van cercaria heeft plaatsgevonden.

\subsubsection{Biotoop en indicatorplanten}

Om de leverbotslakgevoeligheid vast te stellen kan allereest worden gekeken naar de aan- of afwezigheid van factoren die het leverbotslakje nodig heeft om zich te vestigen zoals (periodiek uitgedroogde) poeltjes, natte greppels en 'pootgaten' bij de drinkplaatsen, de zogenaamde waterlichamen. De slakjes bevinden zich vooral aan de rand van deze voorgenoemde waterlichamen. Daarnaast kan gekeken worden naar de aanwezigheid van indicator planten: planten die indicatief zijn voor de milieufactoren waarin het leverbotslakje goed kan gedijen. Deze indicatorplanten zijn: kropaar (Dactylis glomerata), veldrus (Juncus acutiflorus), pitrus (Juncus effusus), fioringras of wit struisgras (Agrostis stolonifera) en Mannagras (Glyceria fluitans) (Rondelaud et al., 2011). Echter, de aan- of afwezigheid van deze planten geeft geen zekerheid op het wel of niet aanwezig zijn van de leverbotslak. In stukken waar deze planten aanwezig zijn, kan meer gericht worden gezocht naar het leverbotslakje zelf.

\subsubsection{Karteren}

Het identificeren van leverbotslakgevoelige percelen middels karteren is niet makkelijk. Het opsporen van de slakjes kan met behulp van een zeefje, maar succes is er vaak alleen onder specifieke omstandigheden: voldoende hoge temperatuur $\left(>10^{\circ} \mathrm{C}\right)$, maar niet te hoog $\left(<25^{\circ} \mathrm{C}\right)$ en voldoende vocht. In andere omstandigheden graven de slakjes zich in, zodat ze niet uitdrogen. Hoe diep zij zich ingraven is niet bekend. Het aantal slakjes kan ook zeer gering zijn, waardoor de kans om ze te vinden vrij klein is.

\subsubsection{Vastellen van besmetting percelen}

Een leverbotgevoelig perceel, zelfs wanneer er ook leverbotslakjes aanwezig zijn, hoeft niet per definitie ook een met leverbot besmet perceel te zijn. Voor een besmetting zijn de aanwezigheid van de (eieren van de) leverbot nodig (verspreid via inscharen besmet vee of aanwezig besmet wild) en de juiste weersomstandigheden. Besmetting van slakjes is vast te stellen door deze onder een microscoop te leggen en het slakje 'te pletten' waardoor de eventueel aanwezige trilhaarlarven vrijkomen.

Shedden (uittreden van cercaria uit de besmette slak) vindt plaats bij regenval én een temperatuur van $10^{\circ} \mathrm{C}$ of hoger. De optimale temperatuur voor vrijlating van deze trilhaarlarven ligt rond de $20^{\circ} \mathrm{C}$. De cercaria hechten zich op de grens van water en lucht aan aanwezig materiaal zoals gras. Door het laten drijven van een cellofaantje in een greppel zullen cercaria zich daar ook op hechten (Gaasenbeek 
et al., 1992). Een cellofaantje is zodoende geschikt om een besmetting, en moment van besmetting, vast te stellen.

\subsection{Eitelling in mest}

$\mathrm{Na}$ besmetting van het vee met leverbot duurt het 10 tot 12 weken voordat de volwassen botten eieren gaan uitscheiden die gevonden kunnen worden in de mest. Dit interval tussen het tijdstip van besmetting en het tijdstip van het terugvinden van die besmetting in de mest is relatief lang. In deze periode veroorzaakt de trektocht van de kleine leverbotten vanuit de dunne darm door de lever naar de galgangen serieuze schade. Het wachten met behandelen tot men leverboteieren in de mest aantreft kan resulteren in onnodig verlies van dierenwelzijn en ziekte én in geval van schapen en geiten zelfs in sterfte.

De eitelling op een mengmestmonster van 5 dieren geeft een goede afspiegeling van de prevalentie van afweerstoffen in het bloed van alle dieren (Knubben-Schweizer \& Torgerson, 2015). Een enkel mestmonster geeft volgens Rapsch et al. (2006) een (te) lage sensitiviteit, van maar 69\%. Dit is ook gevonden door Charlier et al. (2008) bij telling van 10 gram mest. Charlier et al. (2008) geeft daarbij een specificiteit van 93\%. Mazeri et al. (2016) geeft aan dat de specificiteit hoog ligt (99\%) maar de sensitiviteit verschilt tussen de seizoenen: in de herfst wordt de sensitiviteit geschat op $58 \%$, in de winter op $77 \%$ en in de zomer op $81 \%$.

De via een mestmonster vastgestelde infectie kan lang geleden zijn opgelopen. Hierdoor kan niet worden gezegd of een infectie (op basis van een positieve eitelling in de mest) van eerste lactatiedieren is opgelopen op het perceel waar het melkgevend vee is geweid of dat de dieren de infectie al als jongvee hebben opgelopen. De bot kan namelijk tot 26 maanden overleven in de lever (Knubben-Schweizer \& Torgerson, 2015).

\subsection{Titerbepaling in bloed}

Met behulp van Elisatests zijn afweerstoffen tegen leverbot aan te tonen in het bloed. Elisa staat voor 'Enzyme-linked immunosorbent assay'. Ongeveer vier weken na het oplopen van een leverbotbesmetting zijn afweerstoffen in het bloed zichtbaar. In dit project is gebruik gemaakt van de Elisa van Idexx. Deze test spoort specifieke antilichamen op tegen het f2-antigeen van Fasciola hepatica in bloed van runderen of schapen. De test is ook geschikt voor gepoolde monsters. Het gevonden resultaat is het percentage van de positieve controle ( $\% \mathrm{~S} / \mathrm{P}=$ (sample/positieve controle)*100). In tabel 2 staan de interpretaties van de verschillende bloeduitslagen.

De Elisa van Idexx geeft op bloedserum respectievelijk een specificiteit en sensitiviteit van $94 \%$ en 92\% (Rapsch et al., 2006). Volgens Charlier et al. (2008) ligt dit lager: 84\% specificiteit en $84 \%$ sensitiviteit.

Voor een goede interpretatie is het relevant te weten dat antistoffen gemiddeld 6 tot 9 maanden aantoonbaar blijven in het bloed na het wegnemen van de besmetting (Hutchinson \& Macarthur, 2003). Dit impliceert dat een besmetting opgelopen in het najaar, in het daarop volgende jaar nog kan zorgen voor een positieve test op afweerstoffen in het bloed.

Tabel 2 Interpretatie Idexx Elisa testuitslagen antilichamen Fasciola hepatica in bloed en melk (VLG www.vlg-bv.nl)

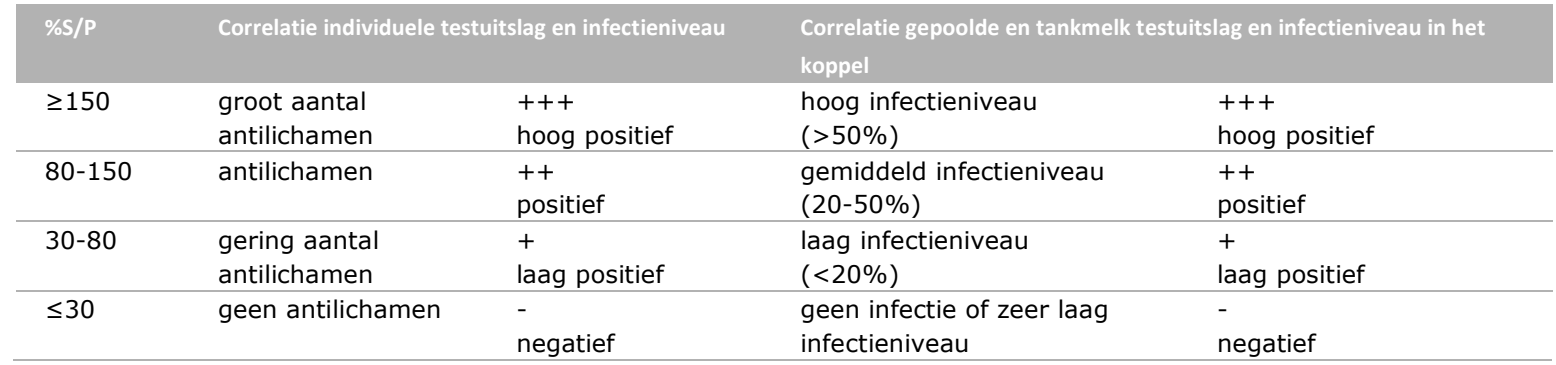




\subsection{Titerbepaling in tankmelk}

Met behulp van een Elisa zijn ook afweerstoffen aan te tonen in de melk. Ongeveer vier weken na het oplopen van een leverbotbesmetting zijn afweerstoffen in de melk te vinden. In dit project is gebruik gemaakt van dezelfde Elisa van Idexx als voor het bloed. In tabel 2 staan de interpretaties van de verschillende tankmelkuitslagen.

De Elisa van Idexx geeft op tankmelk een specificiteit en sensitiviteit van respectievelijk $98 \%$ en $95 \%$ volgens Sekiya et al. (2013). Duscher et al. (2011) geeft juist aan dat de test op tankmelk een lagere sensitiviteit geeft dan op bloed serum. Beide geven aan dat bij een prevalentie van minimaal $20 \%$ positieve dieren de Elisa een positief resultaat geeft.

Het bepalen van een leverbotbesmetting op bedrijfsniveau aan de hand van afweerstoffen in tankmelk geeft de besmettingsstatus (zie tabel 2) weer van de melkgevende dieren. De periode tussen een besmetting en het daarop bepalen van de titer in melk is een belangrijke factor. Afweerstoffen zijn sneller in het bloed aan te tonen dan in de melk. Echter, een negatieve tankmelktest geeft geen $100 \%$ zekerheid dat er geen enkele koe geïnfecteerd is, omdat de Elisa een bepaald niveau aan afweerstoffen nodig heeft om te detecteren (de grenswaarde). Ook kan, net als bij het bepalen van afweerstoffen in het bloed, een positieve test het resultaat zijn van een besmetting in voorgaande najaar.

\subsection{Beoordeling lever van afgevoerde dieren}

Kenmerken van met leverbot geïnfecteerde levers zijn vergrote galgangen, fibrose en/of aanwezigheid van botten. Deze levers worden afgekeurd op het slachthuis. Helaas wordt vaak niet de reden van afkeur gespecificeerd en doorgegeven aan de veehouder. In bijvoorbeeld Denemarken wordt de reden van afkeur van de levers wel geregistreerd (Olsen et al., 2015).

Echter, niet iedere besmette lever zal als zodanig herkend worden. Rapsch et al. (2006) rapporteert voor de inspectie van de lever op leverbotbesmetting een sensitiviteit van $63 \%$.

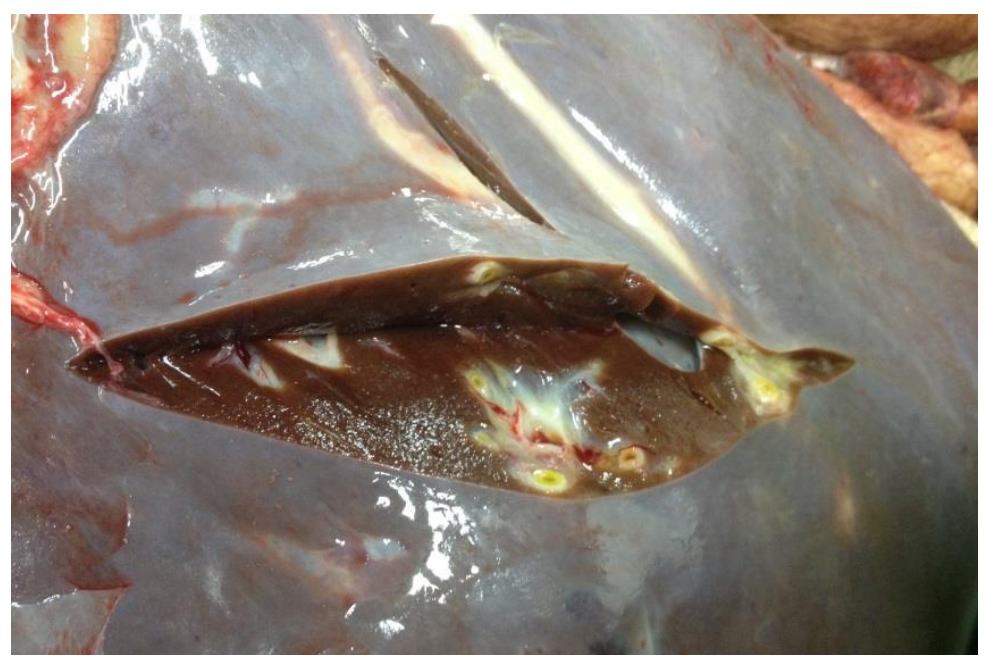

Figuur 4 Een in Nederland afgekeurde lever met vergrote galgangen met aanwijzingen voor ontsteking 


\section{Inzet leverbotinstrument op bedrijven}

In leverbotgevoelige gebieden kunnen besmette en niet-besmette melkveebedrijven naast elkaar liggen. Het verschil tussen deze naburige bedrijven zal minder bepaald worden door de aan- of afwezigheid van een geschikte habitat voor de leverbotslak (Bennema et al., 2009; Olsen et al., 2015). Verschillen zullen waarschijnlijk bepaald worden door het toegepaste management, bijvoorbeeld de manier van weidegang en aankoop van (besmette) dieren (Olsen et al., 2015; Selemetas et al., 2015b). Verschillen tussen groepen in het aandeel besmette dieren binnen een besmet bedrijf worden vooral veroorzaakt door verschil in blootstelling van de verschillende diercategorieën aan leverbot (Byrne et al., 2016).

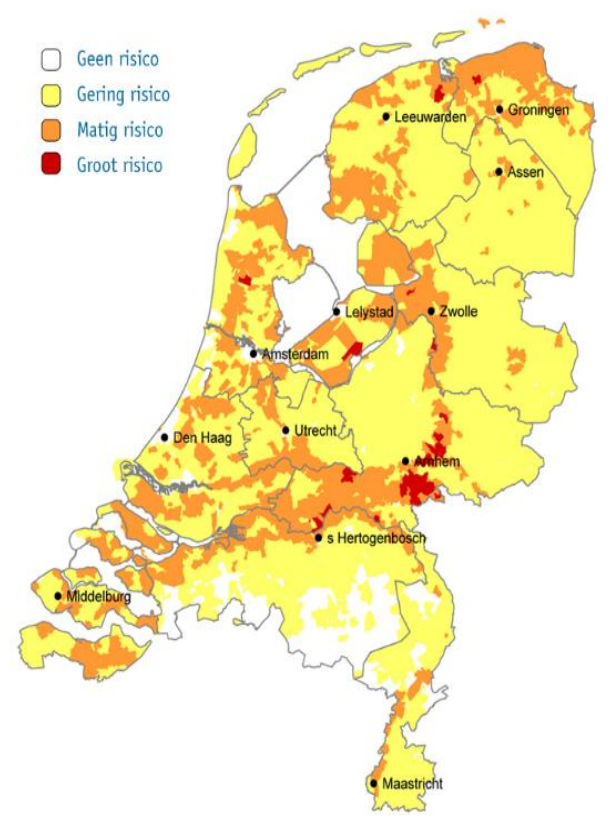

Figuur 5 Risico op leverbotbesmetting in Nederland (definitieve prognose 2015)(bron:

http://www.gddiergezondheid.nl/producten\%20en\%20diensten/producten/leverbot/leverbotadvies)

\subsection{Bedrijven selectie en verzamelde data}

Het uitgangspunt voor de bedrijvenselectie vormt de aanname dat 'buurbedrijven' hun vee in gedeelde polders weiden op percelen met een sterk vergelijkbare habitat voor de leverbotslak. De vergelijkbaarheid in habitat berust met name op landinrichtingsaspecten als grondsoort, uitveendiepten, waterpeilen en perceelafwatering. Evident is dat ook neerslaghoeveelheden en temperaturen die bepalend zijn voor de leverbotcyclus in dezelfde polder vergelijkbaar zijn. Op basis hiervan valt te beredeneren dat het vee op 'buurbedrijven' een vergelijkbare kans loopt om met leverbot besmet te raken en dat verschillen in besmettingsniveaus op 'buurbedrijven' veroorzaakt zullen zijn door verschillen in management. Het vinden van deze verschillen in management die bijdragen aan een leverbotbesmetting kan bedrijven helpen om de omvang van leverbotbesmetting in de toekomst te minimaliseren. 


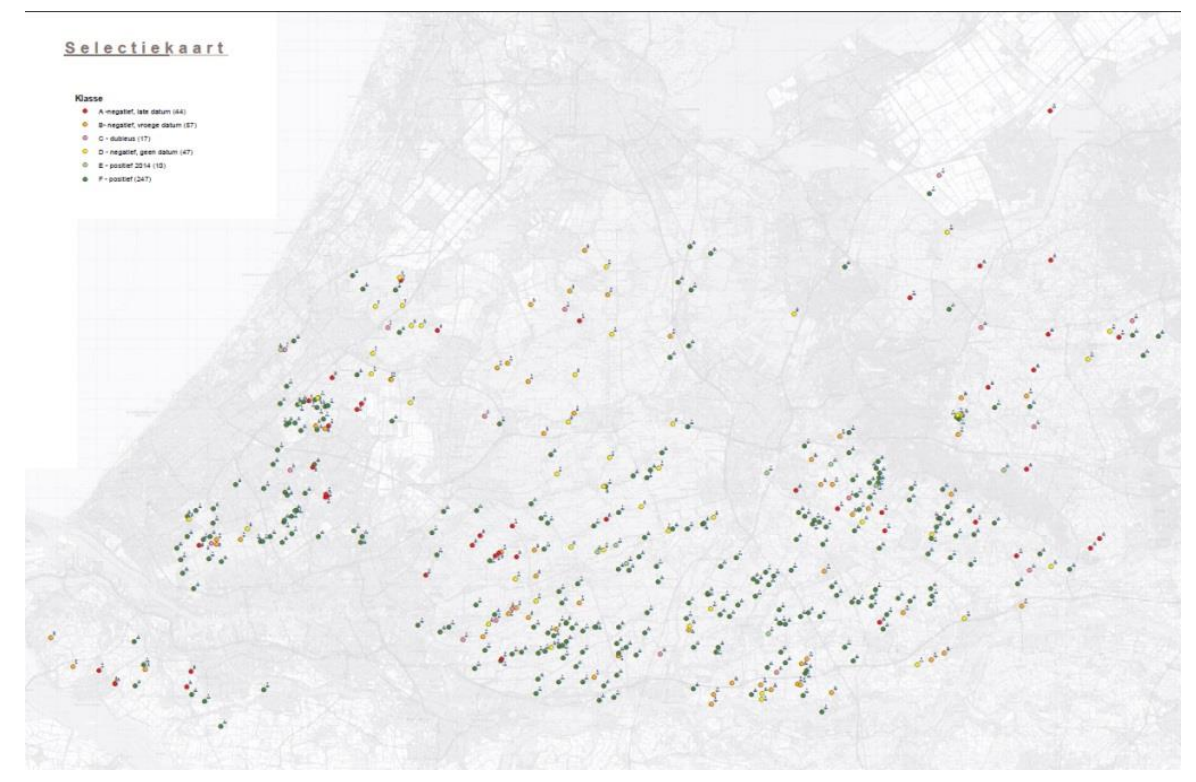

Figuur 6 Geografische initiële selectie van de ca 420 bedrijven op basis van de uitslag van tankmelkonderzoek op leverbotantistoffen en monsternamedatum (dataset Merial)

Om de mogelijke verschillen in management of andere bedrijfsfactoren te achterhalen tussen wel en niet besmette 'buurbedrijven' in Nederland, zijn in 2015 en 2016 positieve bedrijven gematched met een negatief bedrijf uit hetzelfde gebied (vaak perceelsburen ofwel in dezelfde polder) op basis van titer in de tankmelk tot 'koppels' van bedrijven die verschillen in besmettingsniveaus (in het voorgaande en het huidige seizoen). Gezocht is naar matches van bedrijven in gebieden die door de Gezondheidsdienst voor Dieren zijn aangemerkt als leverbotgevoelig (zie figuur 5). In eerste instantie zijn deze gezocht in het Westelijk veenweidengebied. Dit heeft geresulteerd in 11 matches.

Uitgangspunt voor het vinden van matches van positieve en negatieve/laag positieve poldergenoten vormde een meerjarige dataset van tankmelkonderzoeken op leverbotantistoffen (2010-2014) van Merial. Met behulp van deze set zijn ca. 420 bedrijven gerubriceerd op basis van uitslag en monstername datum. Daarna is op basis van postcodes een kaartje opgesteld voor het selecteren van buurbedrijven en poldergenoten (zie figuur 6). Bij de selectie van bedrijven was het streven om een gelijk aantal positieve en negatieve/laag positieve gangbare en biologische bedrijven te verkrijgen. Uit literatuur is gebleken dat op biologische bedrijven de prevalentie voor wat betreft wormbesmettingen hoger ligt t.o.v. gangbare bedrijven (62\% vs. 42\% (Athanasiadou et al., 2002)). Dit kan te maken hebben met de verplichte weidegang voor biologische bedrijven, ook onder omstandigheden die een hogere kans op wormbesmettingen geeft. Een voorwaarde voor deelname van gangbare bedrijven is de toepassing van weidegang.

Potentiële match bedrijven zijn in eerste instantie via een algemene brief geïnformeerd over het onderzoek en uitgenodigd om aan dit onderzoek mee te doen. Ook hun dierenartsen zijn via een brief in kennis gesteld van het onderzoek. Doordat in het Westelijk veenweidengebied onvoldoende matches voorhanden waren, is in een later stadium ook in andere leverbotgevoelige gebieden naar matches gezocht. Dit heeft twee extra matches opgeleverd. De gevonden matches bestonden uit: vijf perceelsburen, zeven in dezelfde polder en één match van twee biologische boeren in verschillende polders.

Bedrijven zijn persoonlijk aangeschreven, of via nieuwsbrieven of bij bijeenkomsten (van bestaande studiegroepen) gevraagd om deel te nemen aan het onderzoek. Ter verificatie van de leverbotstatus, op basis van tankmelk in eerdere jaren, is de tankmelk nogmaals onderzocht op leverbotantistoffen vanaf 4 weken na opstallen. In totaal zijn 27 bedrijven op basis van tankmelktiters en geografische ligging (in dezelfde polder) gematched tot 13 koppels (zie figuur 7) van een leverbot positief en leverbot negatief/laag positief bedrijf (zie tabel 4). Aan één gangbare match is een derde poldergenoot, een biologisch bedrijf, toegevoegd omdat voor dit bedrijf, dat negatief voor leverbot testte in de tankmelk, geen andere positieve poldergenoot beschikbaar kwam. 


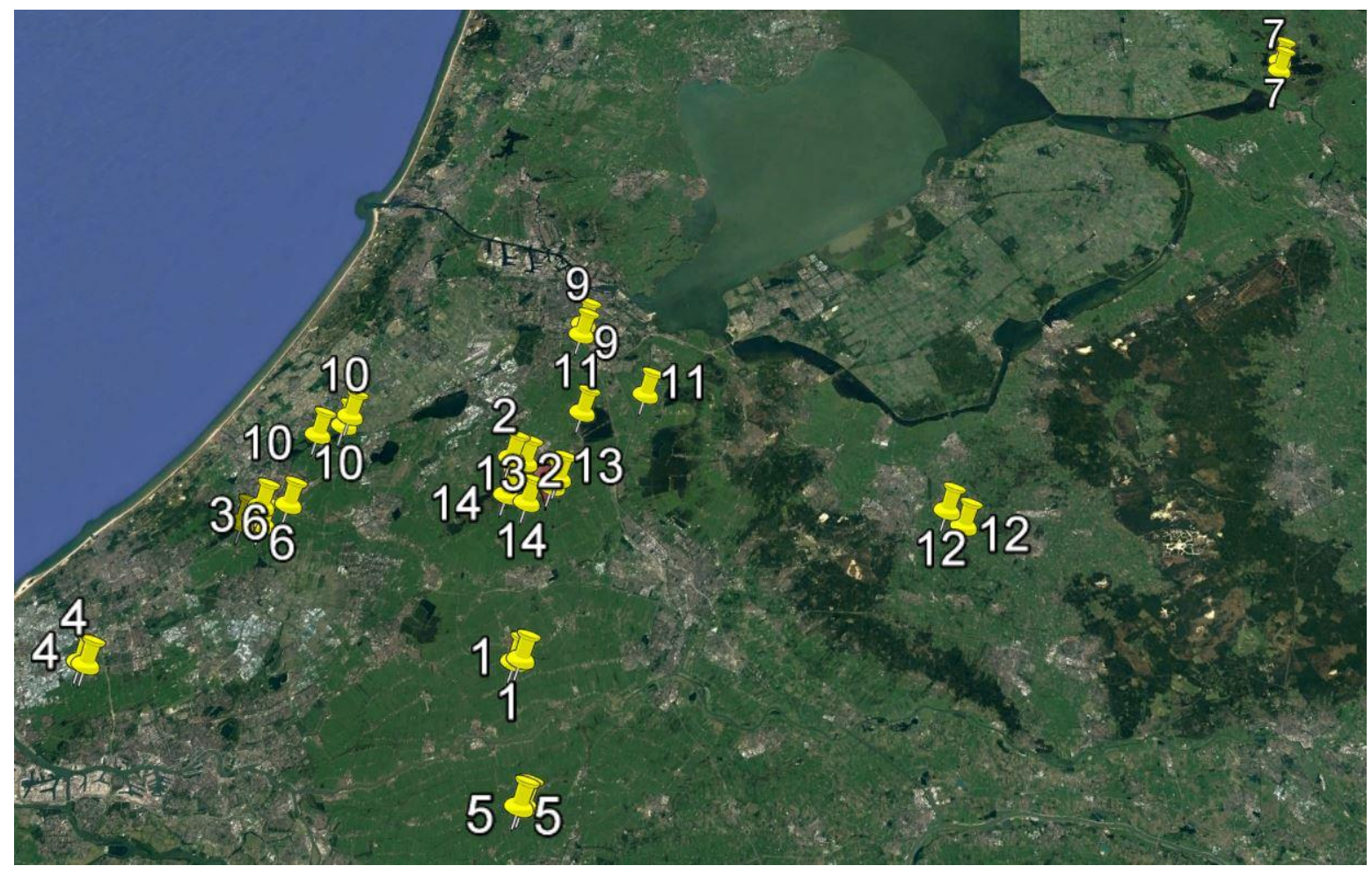

Figuur 713 geselecteerde matches van leverbot positieve en negatieve 'buurbedrijven' (zie ook tabel 4, GoogleMaps)

Van de 27 geselecteerde bedrijven is op 26 bedrijven is tijdens een bedrijfsbezoek het leverbotinstrument (zie hoofdstuk 2) ingevuld en op 25 bedrijven ${ }^{1}$ zijn bloedmonsters genomen. De bloedmonsters zijn in opdracht van de veehouder door de eigen dierenarts genomen vanaf vier weken na opstallen van van tevoren geselecteerde groepen dieren om zo de leverbotstatus van het bedrijf vast te stellen.

Voor het aantal matches betekent het uitvallen van één negatief biologisch bedrijf (geen bloedmonsters genomen) dat ook de gangbare koppelgenoot uit is gevallen. Door de uitval van één gangbaar bedrijf (geen bedrijfsbezoek kunnen plaatsvinden) is ook de biologische koppelgenoot uitgevallen. Hierdoor resteerden nog 11 matches met daarin 23 bedrijven.

Tabel 3 Het aantal getapte bedrijven op basis van de selectie van matchende positieve en negatieve 'buurbedrijven' (zie voor ${ }^{1}$ de bovenstaande tekst)

\begin{tabular}{llll} 
Status & $\begin{array}{l}\text { Aantal bedrijven op basis van } \\
\text { titer tankmelk }\end{array}$ & $\begin{array}{l}\text { Aantal bedrijven op basis van } \\
\text { titers bloed }\end{array}$ & \\
Positief & 12 & 9 & 4 \\
\hline Negatief & 13 & 16 & 6 \\
\hline
\end{tabular}

Van de 11 matches (23 bedrijven) die gemaakt waren op basis van tankmelktiter bleken vanuit de bloedtiters zes matches over te blijven, waaronder de match van drie bedrijven (zie hierboven). Bij één match bleek de uitslag op basis van bloedtiters juist om te draaien van positief naar negatief en andersom. Resultaat was dat zeven matches (15 bedrijven) van de 11 matches over zijn gebleven voor de analyse op verschillen binnen een match van de bedrijfsfactoren en de managementfactoren (zie paragraaf 4.2) waaronder de match met drie bedrijven. 
Tabel 4 Aantal geselecteerde (en war ook bloedmonsters zijn genomen en bedrijfsbezoek heeft plaats gevonden) en werkelijk gemaakte matches voor analyse op basis van de uitslagen van de bloedtiters van een leverbot positief en negatief bedrijf

\begin{tabular}{|c|c|c|c|}
\hline $\begin{array}{l}\text { Positief tankmelk } \\
\text { leverbot }\end{array}$ & $\begin{array}{l}\text { Negatief tankmelk } \\
\text { leverbot }\end{array}$ & $\begin{array}{l}\text { Geselecteerde aantal } \\
\text { matches }\end{array}$ & $\begin{array}{l}\text { Aantal matches op basis } \\
\text { bloed }\end{array}$ \\
\hline Gangbaar & Biologisch & $3 *$ & $2 *$ \\
\hline Biologisch & Gangbaar & 2 & 1 \\
\hline Biologisch & Biologisch & 2 & 1 \\
\hline
\end{tabular}

${ }^{*}$ in dit aantal matches zit een deel van de match die uit drie bedrijven bestaat (biologisch negatief $x$ gangbaar positief $x$ gangbaar negatief)

\subsubsection{Bloedtiters van verschillende groepen dieren}

Het is bekend dat tussen jonge dieren en melkkoeien op hetzelfde bedrijf verschil in leverbotinfectiestatus kan bestaan, vooral omdat deze dieren vaak verschillend worden geweid (Knubben-Schweizer \& Torgerson, 2015). Om de infectiestatus van een bedrijf te bepalen, wordt daarom aangeraden om binnen specifieke groepen dieren van vijf dieren per groep de status te bepalen.

Bij elk bedrijf zijn, voor zover aanwezig, van vier groepen van vijf dieren bloedmonsters genomen door de dierenarts in opdracht van de veehouder om de besmettingsstatus vast te stellen. De vier groepen zijn; runderen met één weidegang (kalveren/pinken), runderen met twee weidegangen (hoog drachtige vaarzen), nieuwmelkte koeien ( $<2$ maanden in lactatie, lactatienummer $\geq 2$ ) en oudmelkte koeien ( $>6$ maanden in lactatie, lactatienummer $\geq 2$ ). In tabel 5 staan de uitslagen van het percentage positieve dieren die per diergroep per bedrijf in de matches zijn getapt. De uitslagen van de analyse op leverbotantistoffen in het bloed bij de melkkoeien week op zes bedrijven in vijf afzonderlijke matches af van wat was verwacht op basis van de uitslagen van de tankmelk. In één match wisselde de status van beide bedrijven waardoor de match als geheel voor de analyse behouden kon worden. Op basis van de bloeduitslag zijn vier matches verloren gegaan en resteerden nog zeven matches. In deze vier matches bleek een verondersteld negatief (2)/laag positief (2) bedrijf op basis van de tankmelk, positief op basis van het bloed van de melkkoeien $(\geq 10 \%)$.

In drie gevallen is op basis van een onverwachte uitslag van het bloed van de melkkoeien aansluitend de tankmelk nogmaals getest: 1 ) Eén bedrijf met 30\% positieve melkkoeien op 20-01-'16 én vooraf aangemerkt als negatief op basis van tankmelk op 16-11-'15 testte op 17-02-'16 nog steeds negatief in de tankmelk, 2) Het 'buur'bedrijf met 10\% positieve melkkoeien op 25-01-'16 testte op 23-02-'16 negatief in de tankmelk en 3 ) een bedrijf met $10 \%$ positieve melkkoeien op 19-02-'16 testte op 0903-'16 laag positief in de tankmelk. In het eerste geval komt de uitslag van de tankmelk antistoffen niet overeen met het percentage positieve melkkoeien. Alle drie betreffen waarschijnlijk grensgevallen qua percentage positieve melkkoeien in de koppel.

De beschrijving van de wijze van bepaling en de gehanteerde grenswaardes van de bloedtiters staat in paragraaf 3.3. 
Tabel 5 Percentage positieve runderen per diergroep per bedrijf in de match

\begin{tabular}{|c|c|c|c|c|}
\hline Match & $\begin{array}{l}\text { Runderen met } 1 \\
\text { weidegang } \\
\text { (kalveren/pinken) }\end{array}$ & $\begin{array}{l}\text { Hoog drachtige vaarzen } \\
\text { (2de, weidegang) }\end{array}$ & $\begin{array}{l}\text { Nieuwmelkte koeien } \\
(<2 \text { mnd in lactatie, } \\
\text { lactatienr } \geq 2 \text { ) }\end{array}$ & $\begin{array}{l}\text { Oudmelkte koeien } \\
\text { ( }>6 \text { mnd in lactatie } \\
\text { lactatienr } \geq 2 \text { ) }\end{array}$ \\
\hline 1 & $20 \%$ & $0 \%$ & $0 \%$ & $0 \%$ \\
\hline 1 & & & $100 \%$ & $100 \%$ \\
\hline 2 & $0 \%$ & & $0 \%$ & $0 \%$ \\
\hline 2 & $0 \%$ & $20 \%$ & $0 \%$ & $20 \%$ \\
\hline 4 & $0 \%$ & $0 \%$ & $0 \%$ & $0 \%$ \\
\hline 4 & & & $100 \%$ & $100 \%$ \\
\hline 5 & $20 \%$ & $20 \%$ & $80 \%$ & $80 \%$ \\
\hline 5 & $20 \%$ & $100 \%$ & $100 \%$ & $100 \%$ \\
\hline \multicolumn{5}{|l|}{6} \\
\hline 9 & $0 \%$ & & $20 \%$ & $0 \%$ \\
\hline 9 & $0 \%$ & $0 \%$ & $20 \%$ & $40 \%$ \\
\hline 10 & $0 \%$ & $0 \%$ & $60 \%$ & $60 \%$ \\
\hline 10 & $20 \%$ & $0 \%$ & $0 \%$ & $0 \%$ \\
\hline 10 & $0 \%$ & $0 \%$ & $0 \%$ & $0 \%$ \\
\hline 11 & $0 \%$ & & $0 \%$ & $20 \%$ \\
\hline 11 & $20 \%$ & $100 \%$ & $100 \%$ & $100 \%$ \\
\hline 12 & $0 \%$ & & $20 \%$ & $60 \%$ \\
\hline 12 & & $0 \%$ & $0 \%$ & $0 \%$ \\
\hline 13 & $0 \%$ & $60 \%$ & $0 \%$ & $0 \%$ \\
\hline
\end{tabular}

\subsection{Analyse}

De data van de zeven overgebleven matches (totaal 15 bedrijven, zie tabel 4) is geanalyseerd op verschillen binnen een match van de bedrijfsfactoren en de managementfactoren zoals bepaald met behulp van het leverbotinstrument (zie bijlage 1 voor de bedrijfs- en managementfactoren). Hierbij is gebruik gemaakt van een variantie analyse (Anova) binnen matches en gegeneraliseerde lineaire modellen (uitgaande van Poisson verdeling).

De data van de 25 bedrijven, waarvan de leverbotbesmetting aan de hand van bloed van dieren uit de verschillende diercategorieën (zie tabel 5) is bepaald, zijn ook geanalyseerd. Hierbij is de infectiestatus voor de jonge dieren (en voor de melkgevende dieren) als volgt bepaald: als één of meer dieren uit groep 1 én 2 (of groep 3 én 4) een positieve leverbottiter heeft dan zijn de jonge dieren (of de melkgevende dieren) positief (positief is hiermee $\geq 10 \%$ van de dieren een positieve titer in de betreffende groep). De uitkomsten van deze analyses staan beschreven in paragraaf 4.4.

\subsection{Uitkomsten}

De 26 bezochte bedrijven hadden gemiddeld 76 (32-193) melk- en kalfkoeien, gemiddeld 47 (0-145) stuks jongvee en een gemiddelde melkproductie van $7.360 \mathrm{~kg}(5.000-10.755 \mathrm{~kg})$ melk per jaar.

De 15 bedrijven die gematched konden worden hadden gemiddeld 91 melk- en kalfkoeien (range van 49 tot 193) en 57 stuks jongvee (range van 0 tot 145 stuks). Daarvan hadden de 7 voor leverbot positieve bedrijven 94 koeien (range 54 tot 193) en 55 stuks jongvee (range 0 tot 145) en $7.407 \mathrm{~kg}$ melk (range 6.337 tot 8.736 ). De acht bedrijven die leverbot negatief waren hadden 88 koeien (range 49 tot 158 ) en 59 stuks jongvee (range van 30 tot 107) en een gemiddelde melkproductie van 8.419 
kg melk (range 6.900 tot 10.755). Het aantal koeien of jongvee en de melkgift verschillen niet significant tussen de leverbot positieve en negatieve bedrijven. In tabel 6 staan deze kengetallen van de 15 bedrijven nogmaals, maar dan ook onderverdeeld naar type bedrijfsvoering: biologisch of gangbaar.

Tabel 6 Weergave van de leverbot positieve en negatieve bedrijven die gematched zijn opgesplitst naar type bedrijf: aantal koeien, jongvee en de melkproductie

\begin{tabular}{|c|c|c|c|c|}
\hline Leverbotdiagnose & positief & & & \\
\hline Gangbaar (G) of biologisch (B): & G & B & G & B \\
\hline Aantal bedrijven: & 4 & 3 & 6 & 2 \\
\hline \multicolumn{5}{|l|}{ Aantal melk- en kalfkoeien: } \\
\hline gemiddeld & 69 & 127 & 99 & 55 \\
\hline $\min$ & 54 & 54 & 57 & 49 \\
\hline $\max$ & 85 & 193 & 158 & 60 \\
\hline \multicolumn{5}{|l|}{ Aantal stuks jongvee: } \\
\hline gemiddeld & 33 & 84 & 66 & 39 \\
\hline $\min$ & 0 & 32 & 30 & 38 \\
\hline $\max$ & 65 & 145 & 107 & 40 \\
\hline \multicolumn{5}{|l|}{ Melkgift (kg per koe/jaar): } \\
\hline gemiddeld & 7884 & 6771 & 8780 & 7336 \\
\hline $\min$ & 6800 & 6337 & 6900 & 7300 \\
\hline $\max$ & 8736 & 7500 & 10755 & 7371 \\
\hline
\end{tabular}

In de volgende paragrafen wordt ingegaan op de gevonden correlaties tussen de factoren en leverbotbesmetting. De factoren die niet genoemd worden waren of niet van toepassing voor de betreffende analyse, bijvoorbeeld het toepassen van zomerstalvoedering voor het melkvee bij de analyse van de status van het jongvee, of er is geen aanwijzing voor een verband gevonden. Door het lage aantal bedrijven dat in de analyse kon worden opgenomen (15 bedrijven) en het feit dat dit een epidemiologische studie betreft, moeten ook de wel gevonden correlaties als niet meer dan aanwijzing voor een (niet noodzakelijk oorzaak-gevolg) relatie tussen de parameters worden gezien.

\subsubsection{Algemene bedrijfstypering en kengetallen}

Binnen de 15 gekoppelde bedrijven zien we voor de parameters die betrekking hebben op de algemene bedrijfstypering een trend $(p=0,09)$ in het percentage sterfte van de melkkoeien. Het percentage sterfte onder de melkkoeien van de positieve bedrijven is gemiddeld $3,3 \%$ vergeleken met gemiddeld $1,4 \%$ op de negatieve bedrijven. Sterfte van geweide kalveren tijdens het weideseizoen of na opstallen door een oorzaak anders dan leverbot komt voor op twee van de zeven positieve bedrijven, terwijl dit niet voorkomt op de acht negatieve bedrijven $(p=0,07)$.

\subsubsection{Reguliere en preventieve bestrijdingsmaatregelen}

Binnen de reguliere bestrijdingsmaatregelen is de totaalscore die het risico op fout behandelen tegen leverbot aangeeft hoger voor de positieve dan de negatieve bedrijven (gemiddelde score van 8,9 voor de positieve bedrijven en 3,3 voor de negatieve bedrijven, $p=0,02$ ). (In het leverbotinstrument is bij de scores bij dit punt uitgegaan van de risico's voor de gezondheid van het vee). Hoe hoger de score, hoe hoger het risico op fout behandelen. Als men niet hoeft te behandelen, kan men ook niet fout behandelen. Als er wel sprake is van een leverbotbesmetting maar er wordt niet behandeld dan is er ook sprake van fout behandelen. In het verlengde hiervan gaan de koeien die niet goed behandeld worden (onbehandelde koeien op de positieve bedrijven) dus ook niet vrij van leverbot in het voorjaar de weide op ( $p \leq 0,001)$. Hierbij moet wel worden opgemerkt dat voor behandelen van melkgevend vee momenteel geen reguliere middelen toegestaan zijn (buiten de cascade regeling).

Op de vier negatieve bedrijven waar ook eigen schapen aanwezig zijn op het bedrijf worden de schapen goed behandeld tegen leverbot. Op het enige positieve bedrijf waar eigen schapen aanwezig zijn is dit niet het geval $(p=0,09)$. In het verlengde hiervan gaan de schapen die niet goed behandeld worden dus ook niet vrij van leverbot in het voorjaar de weide op $(p=0,09)$. 
Zomerstalvoedering bij de melkkoeien als maatregel om leverbotbesmettingen te voorkomen wordt op twee van de acht negatieve bedrijven ingezet en op één positief bedrijf $(p=0,60)$.

Zomerstalvoedering bij de droge koeien, pinken en kalveren wordt op twee van de negatieve bedrijven als preventieve maatregel ingezet en op geen enkel positief bedrijf $(p=0,1)$. Ook een aangepast beweidingsplan om besmetting ontwijkend te beweiden wordt op een groot deel van de negatieve bedrijven toegepast ( 5 van de 8 ) en op één positief bedrijf ( $p=0,05)$. Andere maatregelen zoals de weerstand verhogen van het vee $(p=0,10)$, aangepast slootkantbeheer $(p=0,05)$ en actieve ontwatering indien nodig ( $p=0,10)$ gebeurt op twee negatieve bedrijven en op geen enkel $(n=6)$ positief bedrijf. Op vijf van de acht negatieve bedrijven heeft de veehouder een gericht eigen plan van aanpak om leverbot te voorkomen en bij alle vijf lijkt dit effect te sorteert, terwijl drie van de zeven positieve bedrijven een eigen plan van aanpak heeft waarbij op twee bedrijven de aanpak effect lijkt te sorteren. Echter zijn deze bevindingen niet significant verschillend tussen positieve en negatieve bedrijven.

\subsubsection{Kennis van de veehouder}

Op alle negatieve bedrijven waren de veehouders op de hoogte van de leverbotprognose in hun gebied en weten zij welke factoren een rol spelen bij de opbouw van een besmetting. Twee positieve bedrijven waren niet op de hoogte van de prognose en wisten niet welke factoren een rol spelen in de opbouw van een besmetting (beide $p=0,07$ ). Echter de totale hoeveelheid kennis die een veehouder heeft over leverbot lijkt niet te verschillen $(p=0,4)$ tussen de positieve en de negatieve bedrijven.

\subsubsection{Perceelsituatie en beweiding}

Op het gebied van perceelsituatie en beweiding zien we onder de vier bedrijven die schapen van derden inscharen drie leverbot positieve bedrijven. Op deze bedrijven grazen de schapen ook op leverbotgevoelige percelen. Dit is niet het geval bij het negatieve bedrijf $(p=0,04)$.

\subsubsection{Leverbothistorie en actuele besmetting}

Op vier van de zeven positieve bedrijven vermoedde de veehouder geen actuele besmetting. De veehouders van de negatieve bedrijven vermoedden allen geen actuele besmetting op het bedrijf ( $p=$ $0,02)$. Op alle acht negatieve bedrijven was er geen sprake van een leverbothistorie. Op vier van de zeven positieve bedrijven was er wel sprake van een leverbothistorie $(p=0,005)$.

Op vijf van de zeven positieve bedrijven wordt leverbot niet vastgesteld o.b.v. afgekeurde levers. Zoals verwacht vindt deze vaststelling niet plaats op de negatieve bedrijven $(p=0,07)$.

\subsection{Resultaten melkvee en jongvee}

Naast analyses op de 15 gekoppelde bedrijven zijn de analyses ook uitgevoerd op basis van het al of niet besmet zijn van het melkvee en het jongvee op alle 25 bezochte en getapte bedrijven. De uitslagen van het bloedonderzoek gaven voor sommige bedrijven een discrepantie in besmetting tussen de lacterende dieren (nieuwmelkte- en oudmelkte dieren, verder melkvee genoemd) en de, op moment van bloedafname nog niet lacterende dieren, zoals de kalveren, pinken en hoogdrachtige vaarzen (verder jongvee genoemd). Op drie bedrijven was het jongvee positief voor leverbot en het melkvee negatief. Op 8 bedrijven was dit andersom; jongvee negatief en melkvee positief. Om te kijken welke risicofactoren m.b.t. een leverbotbesmetting een rol spelen binnen deze groepen zijn er aparte analyses uitgevoerd. 


\begin{tabular}{lll} 
Aantal bedrijuen & Status jongvee & Status melkvee \\
6 & Positief & Positief \\
\hline 6 & Negatief & Negatief \\
\hline 2 & Onbekend* & Positief \\
\hline 8 & Positief & Negatief \\
\hline
\end{tabular}

* diergroep niet getapt en niet meegenomen in de verdere analyse

\subsubsection{Resultaten jongvee}

Voor wat betreft de aanwezige gezondheidsproblemen anders dan leverbot op het bedrijf (bv. coccidiose, klauwaandoeningen, etc.; zie vragenlijst) is de gemiddelde totaalscore vijf keer hoger voor de positieve dan de negatieve bedrijven (gemiddelde score van respectievelijk 3,7 vs. 0,$7 ; p \leq 0,001$ ). Des te hoger de score, des te meer actuele gezondheidsproblemen aanwezig zijn. Binnen de reguliere bestrijdingsmaatregelen is de totaalscore die het risico op fout behandelen aangeeft hoger voor de positieve dan de negatieve bedrijven; gemiddelde score van 14,2 voor de positieve bedrijven en 5,9 voor de negatieve bedrijven $(p \leq 0,001)$. Hoe hoger de score, hoe hoger het risico op fout behandelen. Op het gebied van perceelsituatie en beweiding zien we verschillen tussen de positieve en negatieve bedrijven op het gebied van het percentage percelen waar langdurig plassen staan ( $p=$ 0,06 ; POS gem. 5,9\%, NEG gem. 30,4\%) en percelen waar regelmatig/langere tijd water in de greppels staat ( $p \leq 0,01$; POS gem. 48,9\%, NEG gem. 21,6\%). Het is opmerkelijk dat op de positieve bedrijven in minder gevallen water in de greppels blijft staan.

Op alle 14 negatieve bedrijven wordt het jongvee goed (op tijd) behandeld. Op de negen positieve bedrijven is dit op acht bedrijven niet het geval $(p \leq 0,001)$. In het verlengde hiervan gaat het jongvee dat niet goed behandeld is dus ook niet vrij van leverbot in het voorjaar de weide op ( $p \leq$ $0,001)$.

Op geen enkel bedrijf wordt via mestonderzoek vastgesteld of de behandeling effect heeft.

\subsubsection{Resultaten melkvee}

Het gemiddeld aantal stuks jongvee (in het jaar van onderzoek) ligt op de positieve bedrijven met 39 lager dan de negatieve bedrijven $(65 ; p=0,06)$. Het gemiddeld aantal inseminaties per koe per drachtigheid ligt op de positieve bedrijven lager ten opzichte van de negatieve bedrijven $(1,9$ vs. 2,2; $p=0,09)$. De gemiddelde totaalscore voor de kans op een besmetting met leverbot ligt op de positieve bedrijven hoger dan op de negatieve bedrijven $(2,1$ vs. 0,$8 ; p=0,04)$. Ook de totaalscore die het risico op fout behandelen aangeeft ligt hoger $(p \leq 0,001)$ op de positieve bedrijven met 12,5 ten opzichte van 4,2 voor de negatieve bedrijven. Op de negatieve bedrijven worden meer preventieve maatregelen getroffen dan op de positieve bedrijven, wat blijkt uit de gemiddelde totaalscore voor preventieve maatregelen om leverbotbesmetting te voorkomen $(3,3$ vs. 1,1$)(p=$ $0,01)$. Op 10 van de in totaal 14 negatieve bedrijven komen klauwproblemen voor. Dit verschilt $(p=$ $0,07)$ met de positieve bedrijven, waar klauwproblemen voorkomen op drie van de negen bedrijven.

\subsection{Overige bevindingen uit interviews}

In de uitgevoerde interviews benoemt geen enkele veehouder door de dierenarts of in sectie vastgestelde sterftegevallen door leverbot bij schapen, kalveren, pinken of melkkoeien. Slechts één veehouder (buiten de matches om) vermoed sterfte van schapen/lammeren door leverbot in het verleden. Sterfte van geweide kalveren die tijdens het weideseizoen of na opstallen sterven had op twee van de zeven positieve matchbedrijven een duidelijk andere aanwijsbare oorzaak dan leverbot. Een ander positief geïnterviewd (niet in een match opgenomen) bedrijf vraagt zich af of de dunnere mest in het najaar bij het jongvee een gevolg kan zijn van leverbot. Er wordt geen melding gemaakt van verminderde groei of ontwikkeling. En nog weer een ander geïnterviewd positief niet match bedrijf benoemt slijters en leverproblemen als gevolg van leverbot. Binnen de matches benoemt één enkel gangbaar bedrijf afkeur van levers. Daarbuiten is op vier biologische bedrijven sprake (geweest) van afkeur van levers. 
Naast een hoger risico op gezondheidsproblemen kunnen ook de melkopbrengsten teruglopen. Drie positieve bedrijven produceerde echter meer dan hun negatieve matchbedrijf. Tweemaal betrof dit een match van een positief gangbaar en negatief biologisch bedrijf en éénmaal een match van negatief gangbaar en positief gangbaar bedrijf. Het melkproductieniveau ligt op de biologische bedrijven gemiddeld lager in vergelijking met het gemiddelde van de gangbare bedrijven én ook in alle individuele matches van gangbaar maal biologisch lag het productieniveau lager op de biologische bedrijven. Meest opvallend is echter dan geen enkele geïnterviewde veehouder een lagere melkproductie door leverbot benoemd. Enkele geïnterviewde veehouders hadden überhaupt niet verwacht dat hun vee besmet was.

Salmonella kwam voor op vijf bedrijven waarvan op twee bedrijven zowel het melkvee als het jongvee negatief was voor leverbot. Daartegenover staan binnen dit onderzoek 14 leverbot positieve bedrijven die vrij zijn van salmonella. 


\section{$5 \quad$ Effect preventieve maatregelen}

Op een drietal bedrijven is een maatregel geïmplementeerd om de leverbotcyclus te doorbreken. Deze maatregelen zijn naar voren gekomen als perspectiefvol tijdens bijeenkomsten met veehouders. De veehouders die de maatregel hebben toegepast, hebben zelf de keuze voor een maatregel gemaakt op basis van wat in hun optiek het beste bij hun bedrijf past. Op één bedrijf is het frezen van de greppels in de zomer toegepast en op twee van de drie bedrijven is een vorm van ontwijkend beweiden toegepast. Eerder is vastgesteld in Zwitsers onderzoek dat ontwijkend beweiden in combinatie met inscharen van schoon behandeld vee resulteert in een lagere ei-uitscheiding en een lager aantal positieve dieren per bedrijf (Knubben-Schweizer et al., 2010).

\subsection{Greppels frezen in de zomer}

Deze paragraaf beschrijft de aanpak en het resultaat van het frezen van greppels in de zomer als toegepaste maatregel tegen leverbotbesmettingen.

\subsubsection{Doel}

Een greppel is een waterlichaam dat een habitat vormt voor het leverbotslakje. Een niet gefreesde greppel droogt zelden geheel uit als gevolg van overgroeiende vegetatie waardoor het leverbotslakje kan overleven. Het doel is het minimaliseren (en vertragen) van de leverbotbesmetting door het frezen van de greppels in de zomer. Door de greppels bij drogend weer (zomer) uit te frezen wordt de vegetatie en een flink deel van de slakkenpopulatie uit de greppel verwijderd. Door de droogte drogen de op het land geslingerde slakken uit. Het tweede oogmerk van het uitfrezen van de greppels in de zomer, naast het decimeren van de leverbotslakkenpopulatie, is het tegelijkertijd creëren van droge greppels om de omstandigheden waaronder de slakken gedijen te verslechteren. In de zomer gefreesde greppels resulteren mogelijk ook in "harde" greppels die de koeien minder vertrappen. Harde greppels en minder vertrapte greppels hebben een betere waterafvoer wat eveneens bijdraagt aan het beperken van de groei van de slakkenpopulatie, verminderen van de kans op een leverbotbesmetting dan wel het vertragen van het oplopen van een besmetting naar later in het najaar doordat afzetting van de besmetting (cercaria) later plaats vindt. Een indicatie voor vertraging in leverbotbesmetting is opgedaan bij lammeren geweid op in de zomer gefreesde percelen in vergelijking met lammeren die op niet in de zomer gefreesde percelen waren geweid (eerdere bevinding veehouder).

\subsubsection{Aanpak}

Voor een indicatie van het effect van zomerfrezen van de greppels op het oplopen van een besmetting van runderen met leverbot is in 2015 een vergelijkend onderzoek uitgevoerd. Kalveren geweid op een in de zomer gefreesde helft van een leverbotgevoelig-perceel zijn vergeleken met kalveren geweid op de andere, vergelijkbare, niet gefreesde helft van dat perceel. De kalveren zijn nooit eerder geweid en vanaf stal rechtstreeks ingeschaard op één van beide delen van het eerste proefperceel (deel huiskavel). De proefpercelen zijn geselecteerd op hun leverbotgevoeligheid. Daarbij is bekeken of er water in de greppels staat bij forse regenval en in natte perioden en de vastgestelde leverbotbesmettingen bij runderen die in het vorige weideseizoen ook op deze percelen zijn geweid. Ter verificatie van de leverbotgevoeligheid van de proefpercelen is gezocht naar leverbotslakken. Het greppelfrezen in de zomer is bewust zoveel mogelijk afgestemd op een weersverwachting die een grote kans geeft op sterfte door droogte van de uitgefreesde slakken. Om de kans op sterfte van de slakken te maximaliseren is er naar gestreefd om 1) zo kort mogelijk na maaien te frezen en om 2) de grond en het materiaal uit de greppel zover mogelijk uit de greppel vandaan op het perceel te gooien. Om mogelijke besmetting van de kalveren vanuit pootgaten langs de slootkant te voorkomen is tevens gestreefd om te sloten voor inscharen van de kalveren. De kalveren zijn eerst op een perceel bij huis geweid en aansluitend verweid naar een buitenstuk. Het thuisperceel is voor inscharen van de kalveren tweemaal beweid geweest met leverbotpositieve melkkoeien en daarna gemaaid. Het andere perceel is in het voorjaar beweid met oudere pinken in hun tweede weidegang en daarna gemaaid. 
Beide percelen zijn in de winter beweid met eigen schapen. Het effect van deze maatregel is gemonitord door het bepalen van de aanwezigheid van leverbotantistoffen in het bloed. In 2014 heeft ook vee geweid op deze percelen. De melkkoeien en pinken in hun tweede weidegang zijn gedurende enige tijd geweid op respectievelijk het gehele thuisperceel en op het gehele perceel op Oud-Alblas. Vier weken na opstallen na het weideseizoen 2014 was respectievelijk $100 \%$ positief (5 van de 5) en 40\% (2 van de 5) positief. De pinken hebben hun besmetting in 2014 op Oud-Alblas opgelopen. De andere percelen waar ze toen zijn geweid zijn hooggelegen en leverbotongevoelig.

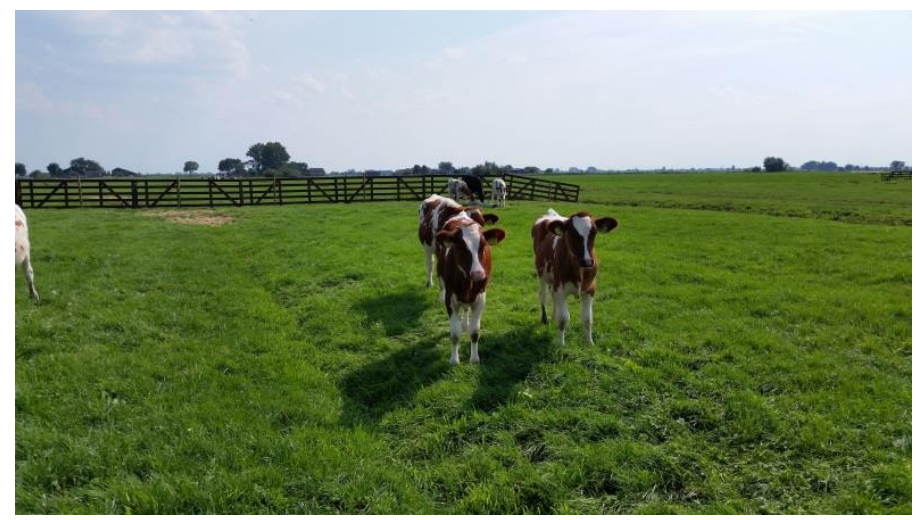

Figuur 8 Kalveren geweid op niet gefreesde deel van proefperceel

\subsubsection{Proefverslag}

Het eerste perceel is eind juli gemaaid en na ca. een week is de helft van de greppel in het perceel gefreesd. Daarna is het drie dagen droog weer geweest en is de greppel opgedroogd. De sloten zijn geschoond voor het inscharen van de kalveren. De 'schone' kalveren zijn begin augustus en een week na het frezen naar buiten gegaan en verdeeld in twee groepen van vijf kalveren. Deze dieren zijn nooit eerder geweid.

In de tweede helft van augustus is naar leverbotslakken gezocht met een deskundige op dit gebied. Op het beoogde tweede perceel zijn voor het greppelfrezen wel enige leverbotslakken gevonden. Dit perceel is het beoogde tweede proefperceel voor het omweiden van de kalveren. Op het eerste proefperceel zijn geen slakken gevonden.

Het tweede perceel is eind augustus gemaaid en gekuild. Dit perceel is pas ca. 14 dagen later gefreesd. Eerder waren er onvoldoende droge omstandigheden. Ook na frezen is geen sprake geweest van droogte waardoor de kans op sterfte van slakken als gering is ingeschat. Vanwege de natte omstandigheden is de sloot van dit perceel niet geschoond voor het omweiden van de kalveren naar dit perceel. De kalveren zijn half september, na ca. zes weken, omgeweid van het eerste perceel naar het tweede perceel.

Eind september is wederom gezocht naar leverbotslakken op beide proefpercelen. De greppels waren droog en er zijn toen geen slakken gevonden.

Om opname van een leverbotbesmetting tijdens aan-en afvoer uit te sluiten zijn de kalveren met een trailer in hun betreffende helft van de proefpercelen gebracht en eruit gehaald. Half oktober zijn de kalveren rechtstreeks vanaf het tweede perceel opgestald. In totaal zijn de kalveren ca. 10 weken geweid. 


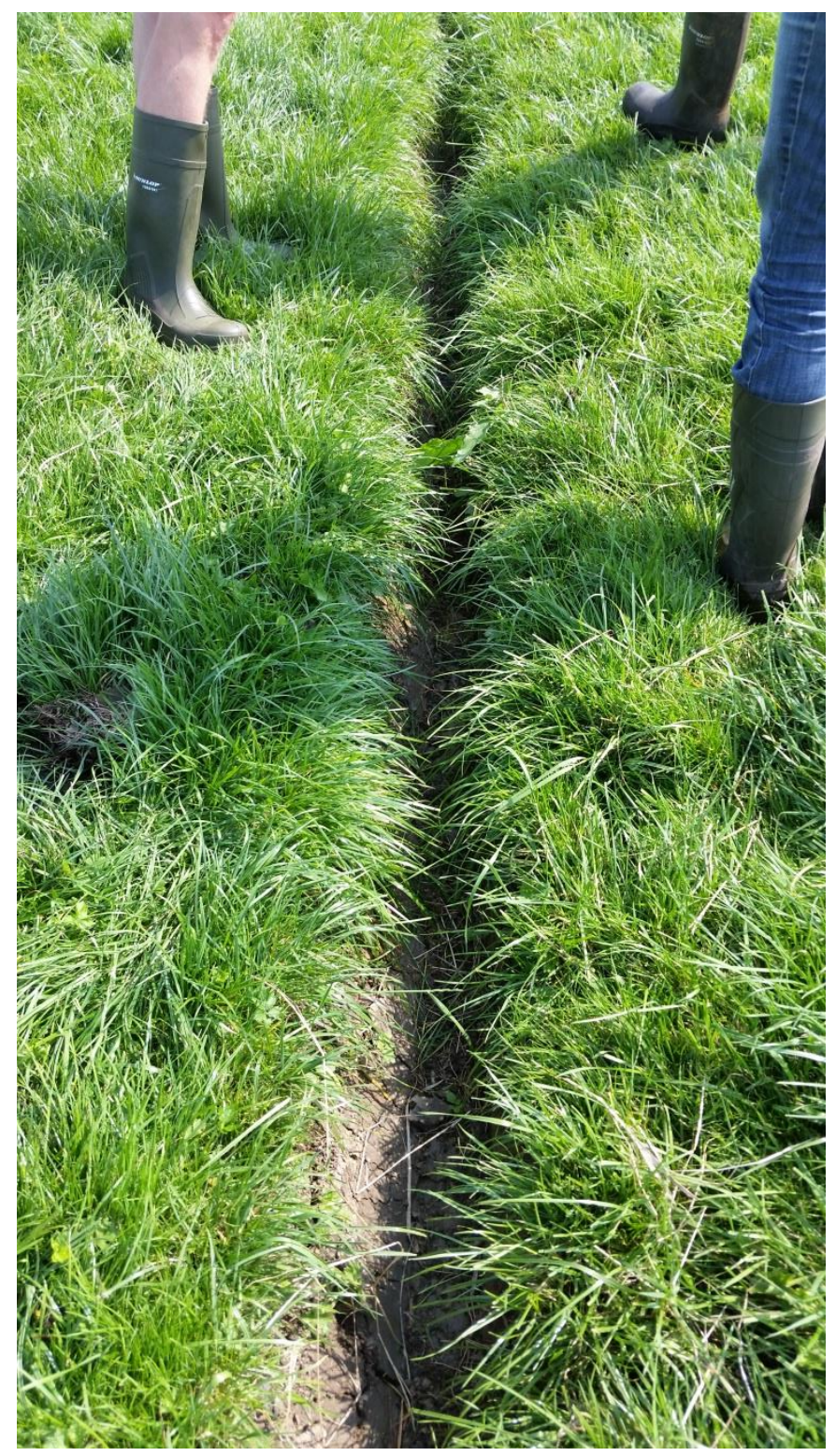

Figuur 9 Greppel gefreesd (2,5 week voor deze foto) in de zomer

\section{Monitoring effect greppelfrezen in de zomer 2015}

De kalveren zijn bloedgetapt op drie dagen na omweiden van het eerste perceel naar het tweede voor vaststelling van een eventuele besmetting vanuit een (late) voorjaarsafzetting. De tweede bloedtap is uitgevoerd op vier weken na omweiden van het eerste perceel naar het tweede. De kalveren zijn eind november voor de laatste keer getapt. Ze waren toen reeds zes weken opgestald. In het overzicht (tabel 8) staan de uitslagen van leverbotantistoffen in het bloed van de kalveren. De tweede uitslag van de monstername op 16-10 geeft de uitslag van de totale leverbotbesmetting opgelopen tussen 98 en 18-9 (40 dagen) op het eerste perceel. De derde uitslag van de monstername op 27-11 geeft de uitslag van de additionele en (totale) leverbotbesmetting opgelopen tussen 18-9 en 16-10 (28 dagen) op het tweede perceel. 


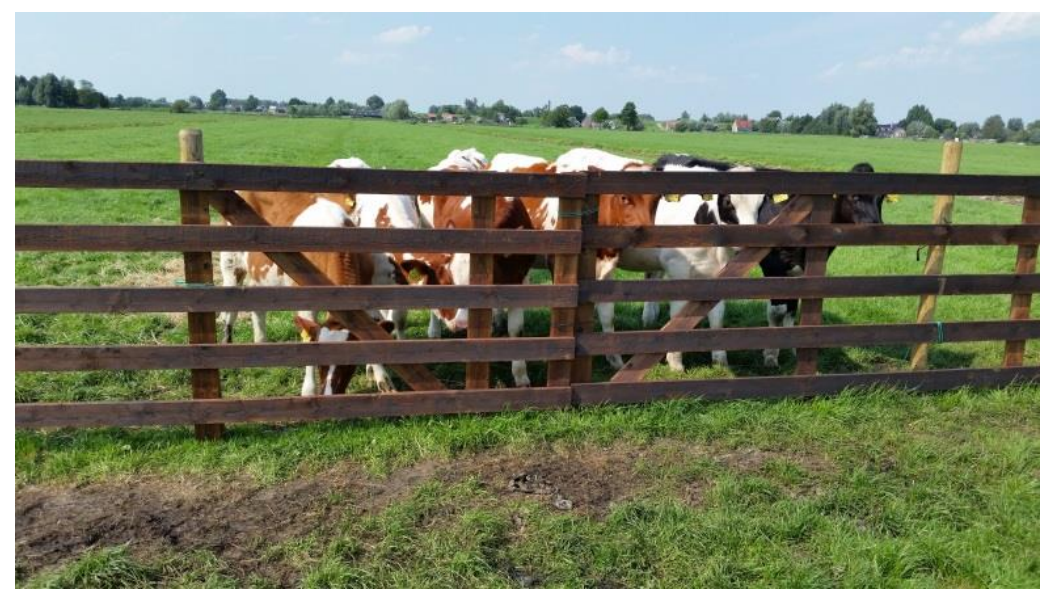

Figuur 10 Kalveren geweid op gefreesde deel van proefperceel

Tabel $8 \quad$ Vergelijking hoeveelheid leverbotantistoffen in bloed (OD-waarde) en leverbotstatus (positief/negatief) van kalveren geweid op het in de zomer gefreesde deel van het perceel met kalveren geweid op niet gefreesde deel van het perceel in 2015

\begin{tabular}{|c|c|c|c|c|c|c|}
\hline & leverbot 21-9 & titer & leverbot 16-10 & titer & leverbot 27-11 & titer \\
\hline 1 & NEG & 13.25 & NEG & 12.57 & NEG & 7.37 \\
\hline 2 & NEG & 4.18 & NEG & 3.26 & NEG & 4.71 \\
\hline 3 & NEG & 11.23 & NEG & 3.63 & POS & 157.54 \\
\hline 5 & NEG & 20.01 & NEG & 8.7 & NEG & 3.27 \\
\hline \multicolumn{7}{|c|}{ kalveren geweid op niet gefreesde deel } \\
\hline 6 & NEG & -1.73 & POS & 68.76 & POS & 197.85 \\
\hline 10 & POS & 100.36 & NEG & 26.95 & POS & 63.73 \\
\hline
\end{tabular}

Op het gefreesde deel van het eerste perceel is geen enkel kalf besmet geraakt. Op het niet gefreesde deel van het eerste perceel zijn bij de tweede tap drie van de vijf kalveren besmet geraakt met leverbot tussen ca. 24-8 en 18-9. Kalf 10 was bij de eerste tap op 21-9 reeds positief bevonden wat duidt op een besmetting van voor 24-8, dus binnen de eerste 14 dagen weidegang. In de aansluitende beweiding tot 16-10 op het niet gefreesde deel van het tweede perceel raken ook de overige twee van de vijf kalveren besmet. Eén van deze twee, kalf 10, lijkt opnieuw besmet. Dit kalf heeft wel beduidend minder antistoffen in het bloed in vergelijking tot de andere vier. Op het gefreesde deel van het tweede perceel raken twee van de vijf kalveren besmet met leverbot. Overall heeft de beweiding van 9-8 tot 16-10 in 2015 van kalveren op niet gefreesd land een $100 \%$ besmetting met leverbot geresulteerd versus $40 \%$ besmetting bij kalveren die in die periode zijn geweid op de gefreesde delen van dezelfde percelen. De gemiddelde titer van de positieve kalveren geweid op de gefreesde delen van de percelen ligt met een OD-waarde van ca. 135 beduidend lager in vergelijking tot de gemiddelde titer van de positieve kalveren geweid op de niet gefreesde delen. Die bedraagt ca. 185 .

\section{Monitoring effect vruchtbaarheid}

Voor een potentieel effect van leverbot op de vruchtbaarheid is in december 2014 op dit bedrijf een eerste verkenning uitgevoerd naar een verschil in de hoeveelheid leverbotantistoffen in het bloed tussen slecht drachtig rakende (inseminaties $\geq 3$ ) en vlot drachtig (na 1 inseminatie) geraakte oudmelkte koeien. De slecht en vlot drachtig rakende koeien hebben beide veel antistoffen in hun bloed. De slecht drachtig rakende melkkoeien $(1 \mathrm{t} / \mathrm{m} 5)$ hebben een iets hogere OD-waarde (zie tabel 
9). Het verschil is op het oog te beperkt en de hoeveelheid leverbotantistoffen in het bloed van melkkoeien lijkt hier niet gerelateerd aan de vruchtbaarheid van de melkkoeien.

Tabel 9 Vergelijking goed en slecht drachtig geraakte melkkoeien op aantal dagen in lactatie, kalfdatum, pariteit, lactatiewaarde, inseminatienummer, drachtigheid en hoeveelheid leverbotantistoffen in bloed (OD-waarde) in 2015

\begin{tabular}{|c|c|c|c|c|c|c|c|}
\hline koe & $\begin{array}{l}\text { Lactatie } \\
\text { dgn }\end{array}$ & $\begin{array}{l}\text { Kalf } \\
\text { datum }\end{array}$ & $\begin{array}{l}\text { Pari- } \\
\text { teit }\end{array}$ & LW & $\begin{array}{l}\text { Ins. } \\
\text { nr. }\end{array}$ & $\begin{array}{l}\text { Status } \\
4-1-15\end{array}$ & OD \\
\hline \multicolumn{8}{|c|}{ Slecht drachtig te krijgen dieren } \\
\hline 1 & 198 & $20-6-2014$ & 4 & 103 & 4 & Geïnsemineerd & 251 \\
\hline 2 & 412 & $18-11-2013$ & 5 & 118 & 7 & Drachtig & 265 \\
\hline 3 & 229 & $20-5-2014$ & 4 & 87 & 3 & Geïnsemineerd & 251 \\
\hline 4 & 344 & $25-1-2014$ & 3 & 100 & 3 & Geïnsemineerd & 225 \\
\hline 5 & 241 & $8-5-2014$ & 5 & 95 & 5 & Geïnsemineerd & 240 \\
\hline Gem & 285 & 25-3-2014 & 4.2 & 101 & 4.4 & & 246 \\
\hline \multicolumn{8}{|c|}{ Vlot drachtig te krijgen dieren } \\
\hline 6 & 326 & $8-2-2014$ & 3 & 106 & 1 & Drachtig & 245 \\
\hline 7 & 223 & $26-5-2014$ & 4 & 82 & 1 & Drachtig & 236 \\
\hline 8 & 235 & $14-5-2014$ & 2 & 100 & 1 & Drachtig & 262 \\
\hline 9 & 309 & $22-2-2014$ & 3 & 107 & 1 & Drachtig & 195 \\
\hline 10 & 338 & $30-1-2014$ & 5 & 99 & 1 & Drachtig & 201 \\
\hline Gem & 286 & 21-3-2014 & 3.4 & 99 & 1 & Vlot drachtig & 228 \\
\hline
\end{tabular}

\section{Meerjarige monitoring}

In 2015 zijn drie categorieën runderen tweemaal getapt te weten 1) drachtige pinken in hun tweede weidegang, 2) droge melkkoeien met lactatienummer 2 of hoger en 3) oudmelkte koeien met lactatienummer 2 of hoger (zie tabel 10) Bij de tweede tap waren de melkkoeien uit groep 2 uit de eerste tap nieuwmelkt. De eerste tap op 18-9-'15 voor het najaar is uitgevoerd om een eventuele voorjaarsbesmetting te kunnen vaststellen. De tweede tap is uitgevoerd vanaf vier weken na op opstallen op 23-12-'15. 
Tabel 10 Monitoring individuele en gemiddelde hoeveelheid leverbotantistoffen in bloed (ODwaarde) en leverbotstatus (positief/negatief) bij verschillende categorieën rundvee op twee momenten in 2015

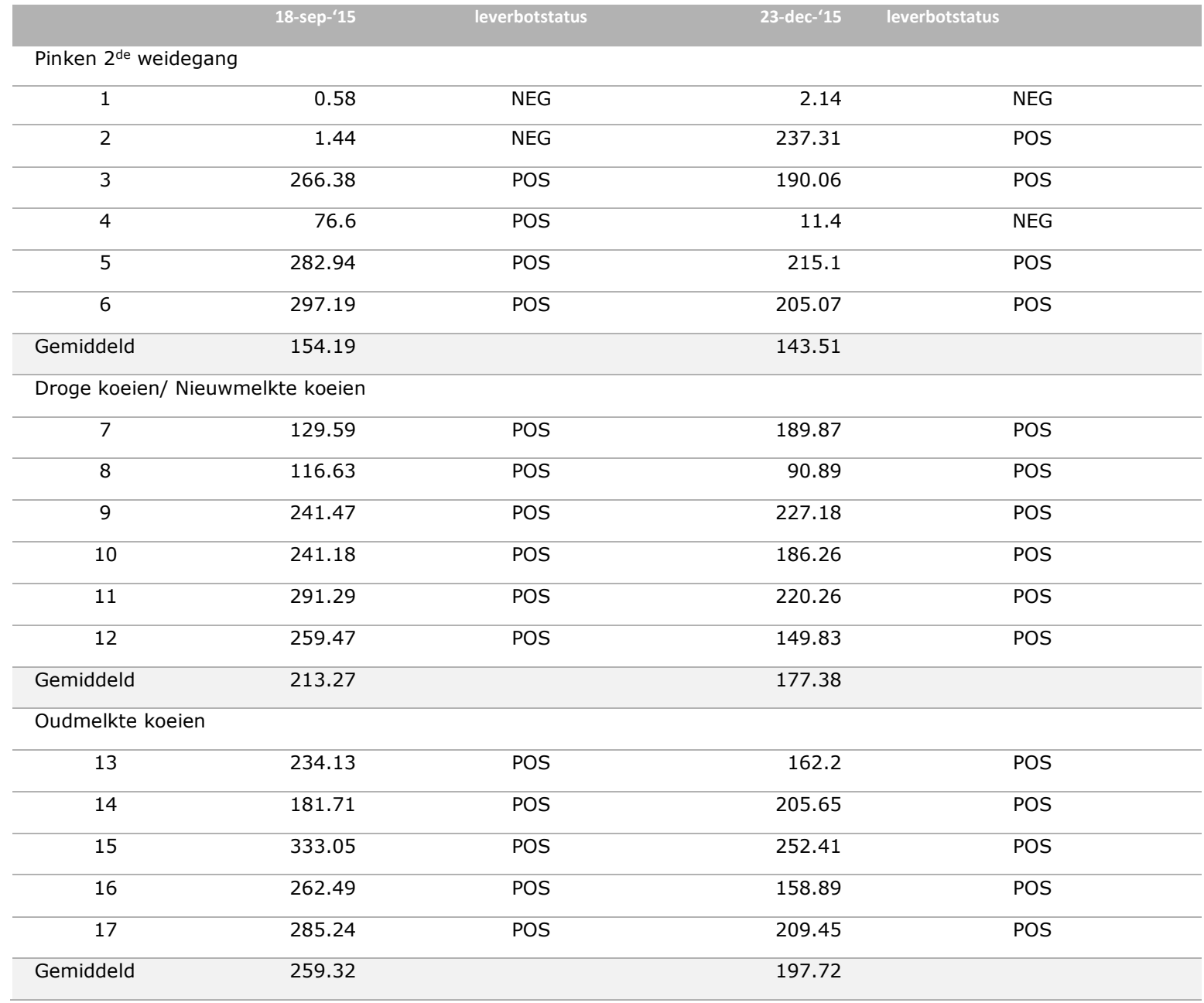

In alle drie de diercategorieën lijkt sprake te zijn geweest van de opname van een voorjaarsbesmetting gelet de hoge gehalten aan leverbotantistoffen in het bloed. Bij één oudmelkte koe en bij één droge koe zijn de OD-waarden toegenomen en één pink is over het najaar positief geraakt. Wat echter het meest in het oog springt is de afname van de OD-waarde van de meeste droge koeien, oudmelkte koeien en pinken over het najaar heen. Dit wijkt af van de verwachte hogere OD-waarde na opstallen door opname van leverbotbesmetting in het najaar. Wat aansluit bij de in 2015 vastgestelde afwijkende opbouw van de slakkenpopulatie door de Werkgroep Leverbotprognose. In afwijking van reguliere patronen was in de zomer en het najaar van 2015 in het westen van Nederland aanvankelijk geen opbouw van de slakkenpopulatie onder invloed van de droogte. De vertraagde opbouw kan de verklaring zijn waarom op één van de 17 runderen tussen 18-9-'15 en opstallen geen leverbotbesmetting heeft opgedaan en de verklaring voor het feit dat de OD-waarden bij 13 van de 15 positieve pinken en melkkoeien is gezakt.

\subsubsection{Conclusies, discussie en aanbevelingen}

Het procentuele verschil in het aantal besmette kalveren tussen kalveren ( 2 x 5 kalveren) geweid op de gefreesde en niet gefreesde delen van de percelen bedraagt $60 \%$ en duidt op een zichtbaar positief effect van zomerfrezen van de greppels op het besmettingsrisico, zowel later als minder. Het verschil in aantal positieve kalveren kan voortvloeien uit minder en latere besmetting op de gefreesde percelen. De vertraging in de besmettingsopname door zomerfrezen bedraagt in dit geval zes tot negen weken.

Zomerfrezen geeft een vertraging van de afzetting van besmetting op het gras (cercaria). Een leverbotbesmetting in het najaar kan, door het vee op te stallen voordat deze afzetting plaats vindt, 
worden geminimaliseerd of zelfs voorkomen. De vertraging van de afzetting door zomerfrezen kan variëren afhankelijk van de weersomstandigheden.

Kalf 10 heeft een enigszins afwijkend besmettingspatroon, eind september positief, halverwege oktober weer negatief en eind november positief. Een mogelijke verklaring is een opname van besmetting in twee fasen, één vroege (lichte) nog resterend op het gras vanuit een (late) voorjaarsafzetting door de leverbotslakken en een daarop volgende najaarsbesmetting waar alle vijf kalveren mee in aanraking zijn gekomen. Het wegzakken van de titer bij tap twee kan een gevolg zijn van weerstandsopbouw na een eenmalige gering opname tussen 9-8 en 24-8 die doortrekt naar de derde tap en verklaart waarom die ook beduidend lager is dan de overige vijf in die groep.

De gefreesde helft en de niet gefreesde helft van beide percelen zijn als vergelijkbaar beschouwd qua leverbotgevoeligheid. Evengoed kunnen we niet uitsluiten dat er in de vertreksituatie van voor het frezen reeds een verschil in hoeveelheid leverbotslakken heeft bestaan op het thuisperceel wat het gevonden verschil in besmetting heeft veroorzaakt in plaats van dat het verschil is voortgevloeid uit het zomerfrezen. Het verdient daarom de aanbeveling om de maatregel te herhalen en dan te wisselen van welk deel van het perceel wel en niet wordt gefreesd.

Hoewel op basis van de gevonden resultaten zomerfrezen veelbelovend lijkt is de onderbouwing met één waarneming op één bedrijf met $2 \times 5$ kalveren nog te summier. Deze bevinding sluit echter wel aan bij de eerder waargenomen vertraging in leverbotbesmetting bij lammeren geweid op in de zomer gefreesde percelen in vergelijking met lammeren die op niet in de zomer gefreesde percelen waren geweid. Gezien de oprukkende resistentieproblematiek is het uiterst zinvol om deze praktische maatregel op meerdere bedrijven te testen.

Ten behoeve van het maximaliseren van het reducerend effect op de slakkenpopulatie zijn een pas gemaaid perceel (of beweid en gebloot) en een periode van droogte na het frezen wenselijk. Naar verwachting overleeft dan een nog kleiner percentage leverbotslakken die door het frezen op het land worden geslingerd. Mogelijk kan zomerfrezen van de greppels onder natte omstandigheden toch ook in bepaalde mate een reducerend effect hebben op de aanwezige hoeveelheid slakken en leverbotbesmetting.

Zomerfrezen is een relatief eenvoudige en praktische maatregel. Het is vooral een kwestie van toepassen op het juiste moment: zo kort mogelijk na maaien en bij verwachte droge dagen is het effect maximaal. Waarschijnlijk levert bloten na weiden dezelfde gewenste droge omstandigheden op als maaien. Daardoor zal bloten na maaien in combinatie met het frezen van de greppels in de zomer eveneens vergelijkbaar kunnen bijdragen aan het decimeren van de leverbotslakkenpopulatie. Afhankelijk van het seizoen kan al in juni met zomerfrezen worden gestart. Hoe eerder in het weideseizoen men ermee begint hoe kleiner de kans dat door natte zomers/vroege herfst percelen niet gefreesd worden voordat de herfst begint. In deze situatie heeft frezen begin september ook nog een reducerend effect gesorteerd.

De zomer gefreesde greppels bleven tot het najaar hard en het dichttrappen van de greppels was ook aanzienlijk minder, aldus de veehouder. Of zomerfrezen het traditionele frezen van de greppels in najaar en winter kan vervangen moet nader worden onderzocht. Hetzelfde geld voor het effect op de ontwateringsfunctie wanneer de greppels standaard twee keer per jaar worden uitgefreesd.

Niet alleen de onderzoekers zien kansen voor deze maatregel ook de veehouder die de maatregel heeft toegepast en de monitoring heeft uitgevoerd, is enthousiast en van plan deze voortaan te gaan toepassen. Tot medio juli 2016 was sprake van relatief natte omstandigheden in de Alblasserwaard waardoor hij het nog niet heeft toegepast.

Ondanks het niet kunnen vinden van leverbotslakken op het eerste perceel in de periode van half augustus en eind september moeten er wel met leverbot besmette slakken hebben gezeten, gezien de positieve kalveren half oktober. De aangetroffen slakken op het tweede perceel moeten besmet zijn geweest gezien de vier kalveren die hun besmetting tijdens hun beweiding daar hebben opgelopen. Het niet kunnen vinden van slakken op enig moment in het jaar is niet altijd een garantie dat het perceel leverbotongevoelig is. Leverbotslakken zoeken lijkt een vak apart. In de drogere perioden houden ze zich dieper in de greppels schuil waardoor ze lastiger te detecteren zijn. 


\subsection{Ontwijkend beweiden (op basis van 'uitrasteren') en verhogen weerstand}

Weides met, of omringd door, waterlichamen (zoals sloten, poelen of greppels) die zelden droog komen te staan zijn de habitat voor het leverbotslakje. Door te voorkomen dat het vee in contact komt met (de randen van) de waterlichamen in de perioden waarin de slakjes de besmetting afzetten, wordt opname van cercariën door het vee voorkomen.

\subsubsection{Doel}

Doel van dit experiment is het voorkomen van opname van leverbot door besmettingsontwijkend te beweiden via het afzetten van greppels, natte plekken en slootkanten met schrikdraad ('uitrasteren'). Én het voorkomen van opname van leverbot door op stal uitsluitend onbesmet vers gras te voeren (zomerstalvoedering met 'veilig' gras) door uitsluitend veilig gras te maaien en geen vers gras op stal te voeren wat groeit langs greppels, op natte plekken of langs slootkanten. Potentieel met leverbot besmet gras afkomstig van deze plekken wordt ingekuild. Daarnaast is beoogd om met de toevoeging van een voeradditief de weerstand tegen leverbot te verhogen en het effect daarvan op besmetting met leverbot vast te stellen.

\subsubsection{Aanpak}

Om het effect van besmettingsontwijkend beweiden en voeren te kunnen vaststellen zijn de melkkoeien in het weideseizoen van 2015 besmettingsontwijkend geweid op de huiskavel en is op stal 'veilig' vers gras gevoerd. In 2014 is deze maatregel ook tot in het begin van het najaar toegepast bij de melkkoeien. Gedurende een korte periode tot aan opstallen is niet ontwijkend geweid. Op basis van een forse leverbothistorie onder de melkkoeien kan gesteld worden dat de huiskavel leverbotgevoelig is. Ter verificatie van de leverbotgevoeligheid is op meerder percelen binnen de huiskavel gezocht naar leverbotslakken. De overige diercategorieën zijn niet ontwijkend geweid op leverbotgevoelige buitenstukken. In de stalperiode $2014 / 2015$ is een voeradditief aan de melkkoeien gevoerd. Om het effect van het voeradditief (dit zou volgens de veehouder de besmetting voorkomen en weerstandsverhogend werken) te kunnen vaststellen is beoogd een vergelijking met besmet jongvee uit te voeren in de stalperiode 2015/2016.

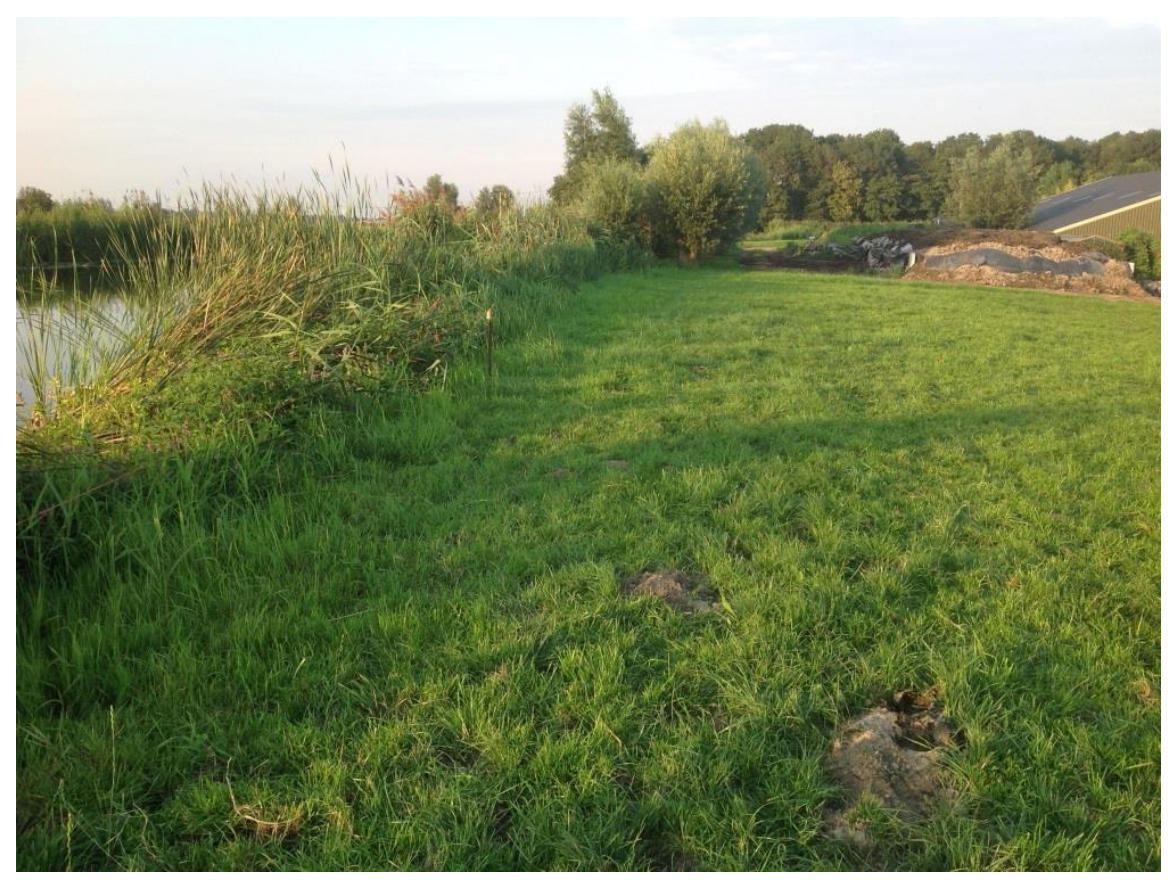

Figuur 11 Ontwijkend beweiden met schrikdraad langs drassige slootkant 


\subsubsection{Acties}

Voorafgaand aan elke inscharing van de melkkoeien in 2015 op een perceel van de huiskavel zijn alle (vermeend) leverbotgevoelige slootkanten en greppels afgezet met schrikdraad. Gedurende het gehele weideseizoen van 2015 zijn de melkkoeien op alle percelen van de huiskavel zodoende besmettingsontwijkend geweid. Dagelijkse werden de melkkoeien standaard gemiddeld drie uur geweid.

Het rantsoen van de melkkoeien is in het weideseizoen aangevuld met vers gras. Voor de zomerstalvoedering is uitsluitend verwacht veilig gras gemaaid. Potentieel met leverbot besmet gras afkomstig uit de slootkanten en greppels is niet vers gevoerd aan de melkkoeien of aan ander vee maar is ingekuild.

Op 30-09-15 is samen met de veehouders in meerdere greppels op de huiskavelpercelen naar leverbotslakken gezocht. In twee afzonderlijke greppels is slechts één leverbotslakje gevonden.

Vanaf vier weken na opstallen zijn op 17-11-'15 en 9-12-'16 respectievelijk vijf pinken met eerste weidegang en tien oudere pinken met twee weidegangen getest op leverbotantistoffen in het bloed. In totaal waren drie van de tien oudere pinken positief. Dit waren te weinig dieren om een goede vergelijking voor het meten van een effect van het voeradditief te kunnen uitvoeren. Uitwijking naar de melkkoeien was vanwege onvoldoende positieve dieren ook niet mogelijk.

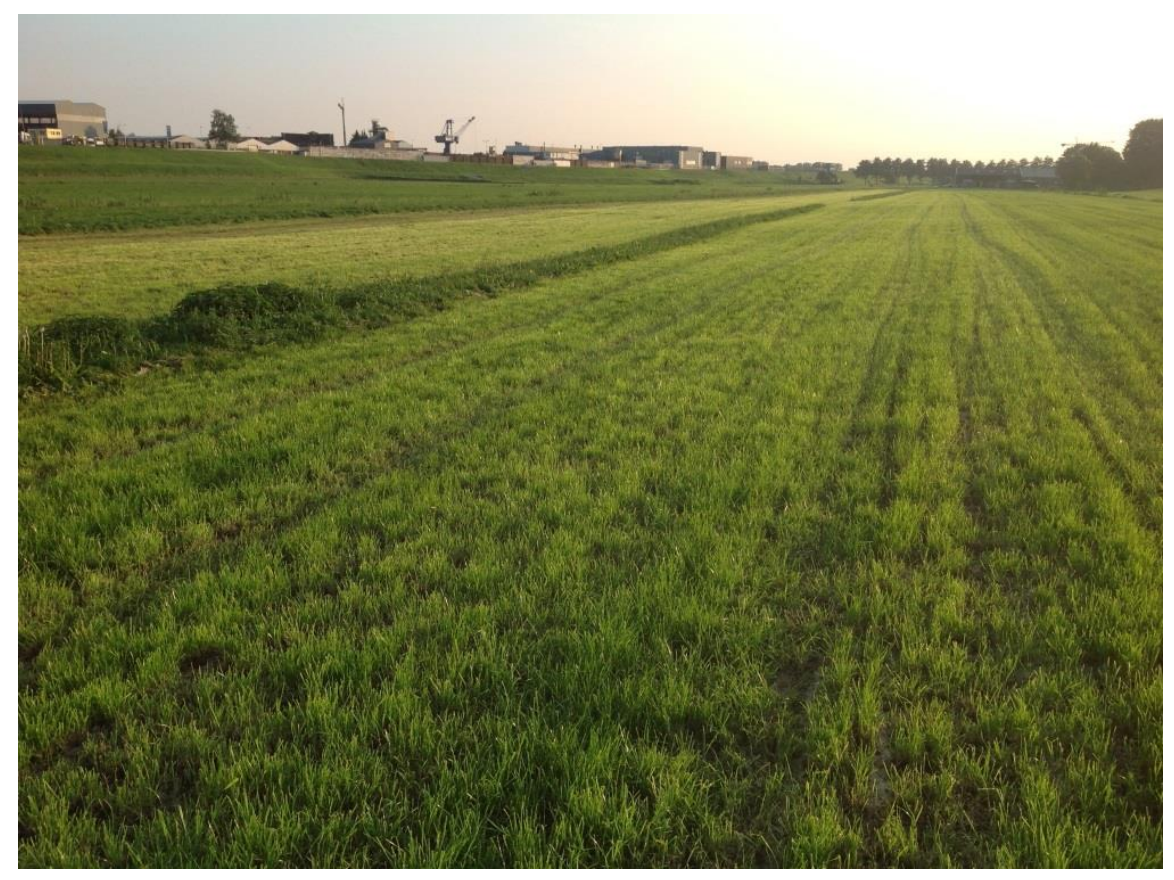

Figuur 12 Ontwijkend maaien voor zomerstalvoedering - greppels niet mee gemaaid

\subsubsection{Monitoring effect besmettingsontwijkend weiden in de zomer 2015}

Het bedrijf heeft een leverbothistorie waarin tot 2013 waarschijnlijk 100\% van de melkkoeien geweid op de huiskavel en $100 \%$ van het jongvee geweid op buitenstukken met leverbot besmet is geweest. Vanwege leverbot en vastgestelde resistentie tegen triclabendazol zijn alle melkkoeien in het weideseizoen tot september op stal gehouden en tot half oktober drie uur per dag geweid. De melkkoeien zijn op stal behandeld met een effectief middel. Bij het tappen eind december 2013 waren drie van de tien melkkoeien, vijf oudmelkt en vijf nieuwmelkt met lactatienummer twee en hoger, positief. De positieve melkkoeien kunnen het gevolg zijn van nieuw opgedane leverbotbesmettingen in het najaar van 2013 of nog het restverschijnsel zijn van de besmetting in 2012.

Eind december 2014 zijn wederom tien melkkoeien, vijf oudmelkt en vijf nieuwmelkt met lactatienummer twee en hoger, getapt. En eveneens vijf oudmelkte vaarzen. Van de melkkoeien was er één positief (10\%) en van de vaarzen twee (40\%). Gedurende het stalseizoen 2014/2015 hebben de veehouders op eigen initiatief reeds ook het voeradditief gevoerd. Een goede effectbepaling is toen niet uitgevoerd. 
In 2015 zijn tien ontwijkend geweide melkkoeien tweemaal getapt. Eenmaal voor het najaar voor het vaststellen van een eventuele voorjaarsbesmetting en de tweede tap vanaf vier weken na opstallen begin december 2015. Beide keren waren twee dezelfde oudmelkte koeien positief (20\%).

November 2015 zijn ook vijf nieuwmelkte vaarzen getapt die na afkalven in 2015 uitsluitend met de melkkoeien op de huiskavel ontwijkend zijn geweid. Deze als drachtige pinken geweid op buitenstukken waren bij tappen eind 2014 alle positief met een gemiddelde OD-waarde van 221. Deze ontwijkend nieuwmelkte vaarzen waren november 2015 wederom alle vijf positief met een gemiddelde OD-waarde van 95.

\subsubsection{Conclusies, discussie en aanbevelingen}

Het ontwijkend beweiden lijkt een effectieve maatregel om het aantal besmette dieren in de koppel en waarschijnlijk ook de mate van besmetting met leverbot aanzienlijk te verminderen. Zowel in 2014 als 2015 was slechts $20 \%$ van de melkkoeien geweid op de leverbotgevoelige huiskavel positief. Terwijl in de vertreksituatie $100 \%$ van de melkkoeien positief was.

Deze waarneming sluit aan bij de verwachting dat de besmetting van de huiskavel door toegepast management flink omlaag is gebracht én bij de afwijkende, vertraagde opbouw van de slakkenpopulatie in het westen van Nederland in 2015 (Werkgroep Leverbotprognose). De aanvoer van nieuwe leverbotbesmetting vanuit de koeien op de huiskavel is sinds het najaar van 2013 beperkt door het toegepaste management van 1) het behandelen in de lactatie en het standaard behandelen van het jongvee met een effectief middel en 2) het niet beweiden van de huiskavel in 2013 tot september. De aanvoer van nieuwe besmetting op de huiskavel kan niet als nul worden beschouwd vanwege mogelijke aanvoer via bedrijfsgrensoverschrijdende besmette hazen en minimaal één besmette melkkoe.

November 2015 waren echter de vijf eveneens op de huiskavel ontwijkend geweide nieuwmelkte vaarzen $100 \%$ positief. De vraag is of dat 1) nog steeds positief is vanuit hun besmetting in 2014 of 2 ) ze opnieuw besmet zijn geraakt ondanks het ontwijkend beweiden in 2015? Nog steeds positief wil zeggen dat leverbotantistoffen tot ca. een jaar na besmetting in het bloed meetbaar zijn. De gemiddelde OD-waarde is wel gezakt van 221 eind december 2014 naar 95 half november 2015. Gezien het verschil in percentage tussen de besmette vaarzen en melkkoeien, respectievelijk $100 \%$ versus $20 \%$ lijkt verklaring 1, nog steeds positief vanuit 2014 meer waarschijnlijk. Een afgenomen OD-waarde past ook bij een oude besmetting. Als het toch om een nieuw opgedane besmetting (antwoord 2) gaat, impliceert dat bij gezamenlijk ontwijkend weiden vooral de nieuwmelkte vaarzen een besmetting oplopen met leverbot omdat alleen zij hebben gegraasd op (de mindere) delen van het perceel die wel besmet waren. Een derde verklaring kan zijn dat 3) deze vaarzen $100 \%$ positief zijn omdat aan hen geen weerstandsverhogend voederadditief is verstrekt in stalseizoen 2014/2015 en aan de slechts $20 \%$ positieve melkkoeien wel. De vaarzen hebben een andere beweidings- en behandelingshistorie als de melkkoeien waardoor ze niet vergelijkbaar zijn. Het beperkte aantal besmettingen bij de melkkoeien kan daarom vooralsnog niet worden toegeschreven aan het voeradditief. Een langdurig weerstand verhogend effect van het voeradditief, gevoerd in het stalseizoen op de besmetting met leverbot in het daaropvolgende weideseizoen ligt niet meteen voor de hand. Een goede vergelijking voor het vaststellen van het effect van het voederadditief was in het stalseizoen van 2015 vanwege onvoldoende besmette dieren op het bedrijf niet mogelijk. In afwijking van reguliere besmettingsontwikkelingspatronen was in het najaar van 2015 in het westen van Nederland aanvankelijk geen opbouw van de slakkenpopulatie onder invloed van de droogte met als gevolg een afwijkende opbouw van de slakkenpopulatie. Toen het eenmaal begon te regenen verliep de opbouw versneld. De vertraagde opbouw verklaart waarschijnlijk waarom in 2015 slechts $20 \%$ van het jongvee op dit bedrijf voor opstallen besmet is geraakt met leverbot in vergelijking tot $100 \%$ in 2013 en $90 \%$ in 2014.

\subsection{Ontwijkend beweiden (op basis van karteren) en inzet van loopeenden}

Op een bedrijf met 70 melkkoeien en ongeveer een zelfde aantal stuks jongvee, dat kampt met chronische leverbotbesmettingen (vastgesteld middels mest-, bloed- en tankmelkonderzoek), zijn twee maatregelen geïmplementeerd om besmetting met leverbot te voorkomen. De eerste maatregel betrof het ontwijkend beweiden op basis van karteren. De tweede maatregel de inzet van loopeenden 
op besmette percelen om de tussengastheer van leverbot weg te vangen en hiermee de cyclus te doorbreken.

Ontwijkend beweiden kan ingezet worden om in de risicomaanden besmetting van het melkvee te voorkomen en toch beweiding toe te passen. In maart 2015 zijn de greppels gefreesd. Eind juli 2015 zijn alle percelen van het bedrijf gekarteerd door een expert om in kaart te brengen welke percelen risicopercelen zijn en welke percelen gebruikt kunnen worden om ontwijkend te beweiden. De inventarisatie van de percelen wijst uit dat alle percelen beschikken over een biotoop die gunstig is voor de tussengastheer. Echter zijn bij de eerste screening van de percelen geen leverbotslakjes gevonden, behalve op een plasdrasperceel. Op het plasdrasperceel werden twee Galba truncatulas gevonden, waarvan er één geïnfecteerd was met de leverbottrilhaarlarve. Op dit perceel zijn de loopeenden ingezet (zie verderop).

\subsubsection{Ontwijkend beweiden jongvee en melkvee}

Voor het experiment ontwijkend beweiden zijn drie percelen geselecteerd die wat hoger gelegen zijn dan de overige percelen van het bedrijf. Na maaien in begin augustus is nog niet eerder geweid jongvee ingeschaard op deze percelen. Tweewekelijks tot en met eind november zijn deze percelen gekarteerd. Op geen van de momenten is de leverbotslak gevonden. Wel zijn er diverse andere slakkensoorten gevonden, waaronder slakken die eveneens behoren tot de poelslakken (Lymnaeidae) familie. Andere gevonden slakkensoorten behoren tot de familie van de diepslakken (Bithyniidae), schijfhorens (Planorbidae) en hoornschalen (Sphaeriidae). Op vier weken na inscharen is bloed afgenomen van het jongvee (controle). Eén dier (diernummer 1; zie tabel 11) had toen reeds een positieve titer tegen leverbot. Na drie maanden grazen op deze percelen zijn de dieren opgestald. Vier weken na opstallen is weer bloed afgenomen van de dieren om het effect van de maatregel vast te stellen. Van de tien dieren zijn acht dieren positief bevonden, en twee dieren zijn negatief gebleven (diernummer 5 en 10; zie tabel 11). Omdat de dieren positief waren, en er dus zeker leverbotslakjes aanwezig zouden moeten zijn in de greppels of slootkanten van de percelen, zijn de percelen weer gekarteerd in het voorjaar (maart en april 2016). Wederom zijn er geen slakjes gevonden. Dit is niet alleen in tegenspraak met de gevonden besmette dieren maar ook in tegenspraak met de leverbotprognose voor het voorjaar van 2016 (de ontwikkeling van slakjes is in die winter niet tot stilstand gekomen maar is actief gebleven tot in het voorjaar).

Tabel 11 Leverbotantistoffen in bloed (OD-waarde) jongvee, maatregel ontwijkend beweiden (tapdatum 11/9/2015 en 16/12/2015)

\begin{tabular}{|c|c|c|c|}
\hline \multirow[t]{2}{*}{ diernummer } & 11-sep-'15 & \multicolumn{2}{|c|}{ 16-dec-'15 } \\
\hline & 1 & 96.97 & 242.49 \\
\hline & 2 & 2.27 & 152.84 \\
\hline & 4 & -1.08 & 233.83 \\
\hline & 5 & 0 & 9.55 \\
\hline & 7 & -5.09 & 175.32 \\
\hline & 8 & 12.77 & 135.42 \\
\hline & 9 & 0.76 & 242.59 \\
\hline & 10 & 3.58 & 11.69 \\
\hline
\end{tabular}

\subsubsection{Inzet loopeenden ten behoeve van beperken en voorkomen leverbotslak en doorbreken van de leverbotcyclus}

Het plasdrasperceel waar twee leverbotslakjes tijdens de eerste kartering zijn gevonden is gebruikt voor het experiment met de loopeenden. Het perceel is opgedeeld in twee stukken; één stuk met de loopeenden en een controlestuk. Tweewekelijks zijn beide stukken gekarteerd om de hoeveelheid leverbotslakjes in kaart te brengen. Echter zijn er gedurende de gehele proef geen leverbotslakjes meer gevonden, zodat de effectiviteit van de loopeenden niet vastgesteld kan worden. 


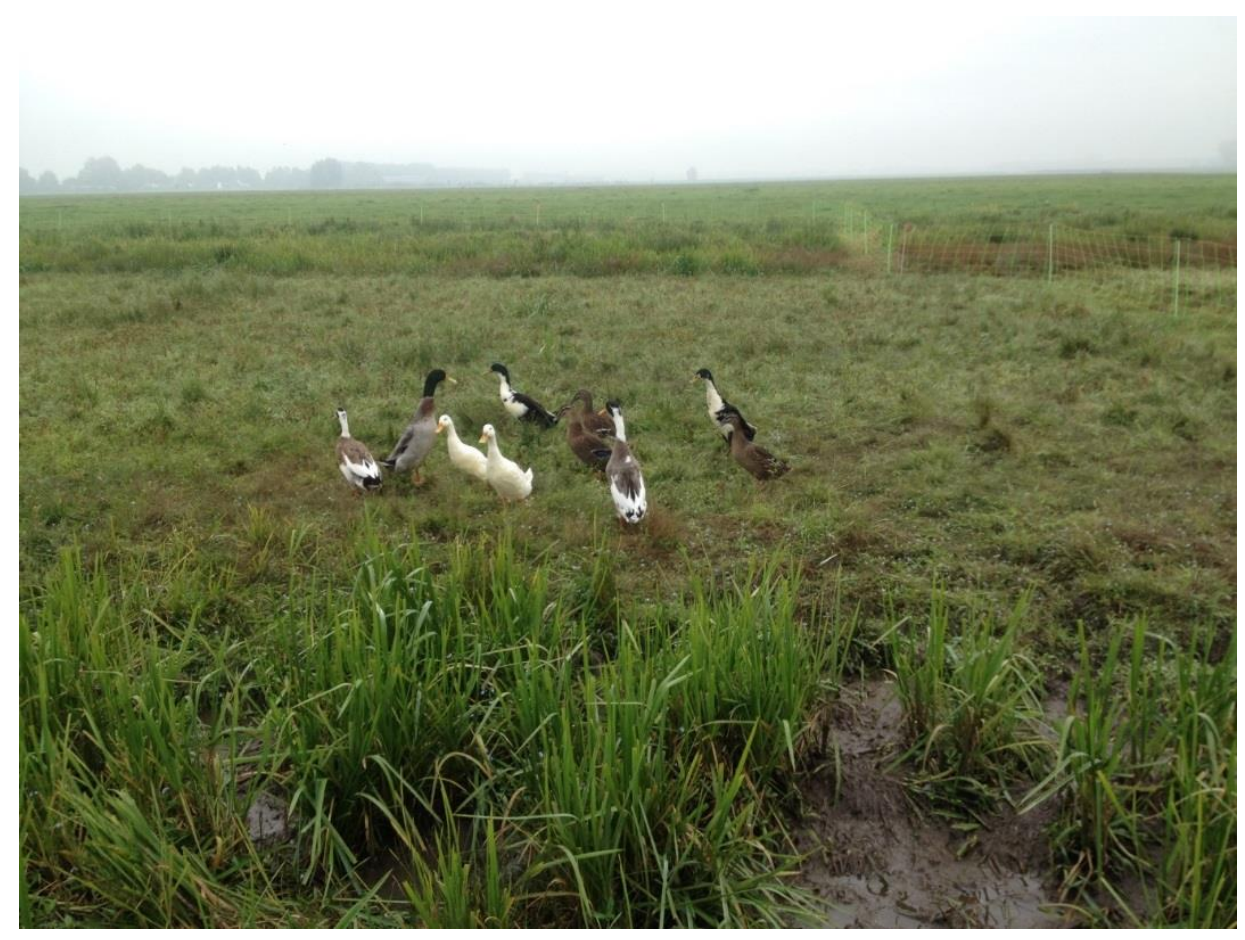

Figuur 13 Loopeenden op het proefstuk van het plasdrasperceel

\subsubsection{Praktische aspecten gebruik loopeenden}

Loopeenden zijn erg honkvast en bij verhuizing naar een ander bedrijf of naar een andere locatie binnen een bedrijf zijn de dieren gedesoriënteerd. Dit maakt hun directe inzet beperkt. Naast een benodigde gewenningsperiode is het houden van de dieren op een bepaalde locatie lastig gebleken. De eenden hadden weinig ontzag voor de schriknetten. Ze vlogen door de mazen heen of fladderden over de heining heen. De effectiviteit van de loopeenden hebben we om die reden niet kunnen bepalen.

Omdat de proef door de bevindingen (slechts twee leverbotslakjes gevonden) en de moeilijkheid van het inzetten van de loopeenden niet uitgevoerd is zoals oorspronkelijk in de opzet staat, is geprobeerd om de inzetmethode van de loopeenden van Judith van Andel uit te voeren. Hierbij is een besmet perceel (bewezen vanuit geïnfecteerd jongvee dat schoon het perceel op ging en besmet is geraakt) in tweeën gedeeld en zijn de greppels op het perceel ook op het midden volledig afgescheiden van elkaar. Op één deel van het perceel zijn de loopeenden ingezet om zo de leverbotslakjes weg te eten uit de greppel. Het andere deel van het perceel diende als controle. Op beide percelen zijn we niet toegekomen aan het inscharen van jongvee, omdat de eenden niet binnen het gebied van de afgezette greppel bleven (vlogen eroverheen).

\section{Mestmonsters}

Naast het karteren en bloedonderzoek is door een expert bij tien willekeurige dieren op het bedrijf een mestmonster genomen om te controleren op leverboteieren. In acht van de tien mestmonsters zaten leverboteieren. In deze monsters werden als toevalsbevinding ook pensboteieren aangetroffen. In twee van de tien mestmonsters kwamen geen leverboteieren, maar wel pensboteieren voor.

\subsubsection{Conclusies}

Het inzetten van loopeenden is praktisch lastig als je de dieren op bepaalde plekken wilt houden en wilt werken met controles.

Karteren is niet zomaar te doen. Ondanks dat de omstandigheden (vochtige greppels/water in de greppels en juiste temperatuur) positief waren voor de leverbotslakjes op de dagen van karteren hebben de onderzoekers en de expert, op twee leverbotslakjes na bij de eerste kartering, geen leverbotslakjes meer gevonden, ondanks dat het vee wel besmet is geraakt en dit duidt op hun aanwezigheid. Dit kan er op duiden dat andere factoren ook van belang zijn voor de aan-/afwezigheid van leverbotslakjes en de kans op het vinden van de leverbotslakjes. Dit leidt tot de conclusie dat er meer kennis nodig is van de leverbotslakjes om de kans op het vinden van leverbotslakjes in gebieden 
waar ze voorkomen te vergroten. Vooralsnog is in dit onderzoek gebleken dat het niet vinden van leverbotslakjes geen garantie is voor het uitblijven van een besmetting.

De aanwezigheid van vele andere slakkensoorten in de greppels en slootkanten van de percelen van het proefbedrijf doet de vraag opkomen of in Nederland ook andere slakkensoorten tussengastheer zijn van de leverbot. Uit verschillende onderzoeken in het buitenland is bekend dat de Galba truncatula niet de enige tussengastheer is. Onderzoek uit België en Luxemburg toont aan dat er andere slakken soorten geïnfecteerd kunnen zijn. Naast de Galba truncatula is tevens de Radix balthica gastheer van de leverbottrilhaarlarve. Ook de ondersoort Radix labiata kan worden gezien als een tussengastheer. Deze slak is tevens familie van de Lymnaediae (Caron et al., 2007; Caron et al., 2014). 


\section{6 \\ Toepasbare kennis om besmetting met leverbot te voorkomen}

Op basis van het literatuuronderzoek, het ontwikkelde en toegepaste instrument en de toegepaste maatregelen op praktijkbedrijven is in dit hoofdstuk beschreven welke kennis relevant is om besmetting met leverbot te voorkomen.

\subsection{Leverbotinstrument}

Het bepalen van de relevante risicofactoren op een bedrijf kan met behulp van het ontwikkelde leverbotinstrument. Met het instrument is een getrainde interviewer (met voldoende diepgaande kennis van herkauwers en leverbot) in staat om samen met de melkveehouder de risicofactoren van diens bedrijf in beeld te brengen. Op basis van de aanwezige risicofactoren kan men bepalen welke diergroepen kans lopen op een leverbotbesmetting én kan men een selectie maken van groepen dieren voor bloedtiterbepalingen. Met deze informatie krijgt de veehouder inzicht in de leverbotstatus van zijn bedrijf en inzicht in de mogelijkheden om een besmetting met leverbot te voorkomen of te reduceren.

\subsection{Besmetting vaststellen}

Besmetting van de dieren is vast te stellen vanuit melk, bloed, mest of door afkeur van de lever (slachtinformatie). In figuur 14 staat de leverbot-besmettingsroute schematisch weergegeven.

\subsubsection{Identificeren leverbotgevoelig perceel}

Percelen die leverbot gevoelig zijn, zijn op te sporen aan de hand van de aanwezigheid van het juiste biotoop voor het leverbotslakje (indicatorplanten, water). Het per perceel daadwerkelijk opsporen van het leverbotslakje (karteren) is lastig. Niet alle factoren die maken of de wel aanwezige slakjes te vinden zijn, zijn blijkbaar bekend. Met name het moment in het jaar, en de aan dat moment gerelateerde populatie-omvangsdynamiek én ontwikkelstadium waarin ze verkeert, zijn sterk bepalend voor de vindbaarheid van de slakjes.

\subsubsection{Besmetting van dieren vaststellen}

Essentieel voor het verkrijgen van de juiste informatie over de actuele leverbotstatus is de keuze van de juiste monsternamedatum. Men kan het beste een tankmelkmonster vanaf 4 weken na opstallen nemen. Dit ter voorkoming van onterechte negatieve uitslagen en omdat leverbot vooralsnog met name een najaarsinfectie is. Percelen raken overwegend pas in het najaar besmet en in theorie kan de leverbotbesmetting pas op het laatste perceel voor opstallen met de laatste happen gras zijn opgenomen. Daarnaast duurt het vier weken voordat antistoffen in de melk meetbaar zijn met de huidige gebruikte tests. Hetzelfde geldt voor bloed. De tankmelk gecombineerd laten testen op maagdarmworm- en leverbotinfecties eerder of te vroeg in het najaar (september, oktober, november), kan voor leverbot onterecht negatieve uitslagen opleveren.

Vanwege verschil in beweidingshistorie is de leverbotstatus gebaseerd op tankmelk- of bloedonderzoek van het melkvee niet maatgevend voor het jongvee (en de schapen). Het is raadzaam om elke groep met een eigen beweidingshistorie separaat te testen op leverbot voor een bedrijfsbreed inzicht in hun status. Dit inzicht is essentieel voor een eventuele effectieve behandeling. Een positieve tankmelk uitslag wil ook niet zeggen dat alle melkkoeien besmet zijn. De positieve uitslag kan veroorzaakt zijn door de melkkoeien zelf en/of door de elders geweide nieuwmelkte vaarzen of droogstaande melkkoeien en/of door aangevoerde runderen. Daarvoor is eveneens aanvullend 
individueel melk- of bloedonderzoek gedifferentieerd naar groep van melkgevende runderen met een vergelijkbare beweidingshistorie nodig.

Om te kunnen beoordelen of het om een actuele besmetting gaat, als de lever is afgekeurd onder de noemer "leverbot", is nadere typering (littekenweefsel, recente aantasting en/of levende botten) nodig. Tot op heden gebeurt deze terugkoppeling op zeer beperkte schaal. Uitsluitend vanwege leverbot afgekeurde levers van geslachte dieren die maximaal één weidegang hebben gehad (lam en rund) zijn zeer waarschijnlijk actuele leverbotbesmettingen. Het gros van de geslachte runderen afkomstig van melkveebedrijven is echter vaak ouder dan twee jaar en is in meerdere seizoen geweid. Pas wanneer de reden van afkeur wordt gedifferentieerd naar levende botten (en aangetast parenchym weefsel) en/of oud letsel (verkalkte galggangen, driehoekslevers), kan worden beoordeeld of sprake is van een actuele of oude besmetting. Deze differentiatie is wenselijk om de juiste vervolgacties (behandelen of monitoren tank en/of bloed in de toekomst) te kunnen nemen. Bij het ontbreken van de nadere typering bij runderen met meer dan één weidegang kan een afgekeurde lever geen aanleiding zijn tot behandelen. Het is namelijk goed mogelijk dat de afgekeurde lever het gevolg is van een oude besmetting (van jaren terug) én de koe bij slachten niet geïnfecteerd was. Het is zelfs mogelijk dat besmetting is opgedaan doordat jongvee geweid is op leverbotgevoelige buitenstukken terwijl de huiskavel leverbotongevoelig is.

\subsection{Behandelen van besmette dieren}

In Nederland zijn vanaf 2014 geen geregistreerde geneesmiddelen beschikbaar tegen leverbot voor melkgevende dieren en dieren die al lacterend zijn geweest. De meeste leverbotmiddelen zijn niet goedgekeurd voor gebruik bij rundvee dat melk voor menselijke consumptie produceert, ook niet tijdens de droogstand. De middelen mogen ook niet worden gebruikt tijdens het laatste trimester van de dracht bij vaarzen die zijn bestemd voor de productie van melk voor menselijke consumptie. In geval van noodzakelijke behandeling (diagnose ernstige leverbotbesmetting vastgesteld door een dierenarts) kan de dierenarts onder voorwaarde gebruikmaken van de cascaderegeling (Artikel 22 van het Diergeneesmiddelenbesluit) en Zanil voorschrijven. Hierbij is de wachttijd voor melk 7 dagen en bij biologische bedrijven 14 dagen.

Alleen jongvee mag nog behandeld worden. Het verdient de aanbeveling om de dieren pas twee weken na opstallen te behandelen met een middel met als werkzame stof triclabendazol, mits er op het bedrijf geen resistentie bestaat tegen deze werkzame stof. Triclabendazol is de enige werkzame stof die vrijwel alle stadia van de leverbot aanpakt, behalve de eerste twee weken na opname. Indien middelen met andere werkzame stoffen worden toegepast, is vaak een langer interval tussen opstallen en behandelen nodig omdat deze middelen minder jongere stadia doden.

Slachtinformatie over afkeur van de lever is alleen aanleiding tot behandeling (mits toegestaan) van de dieren met dezelfde beweidingshistorie als de diagnose vermeld dat er levende botten zijn aangetroffen. In geval het om een afgekeurde lever gaat vanwege oude littekenweefsel (verkalkte galggangen, driehoekslevers) geeft de slachtterugkoppeling geen inzicht in de huidige leverbotstatus. 


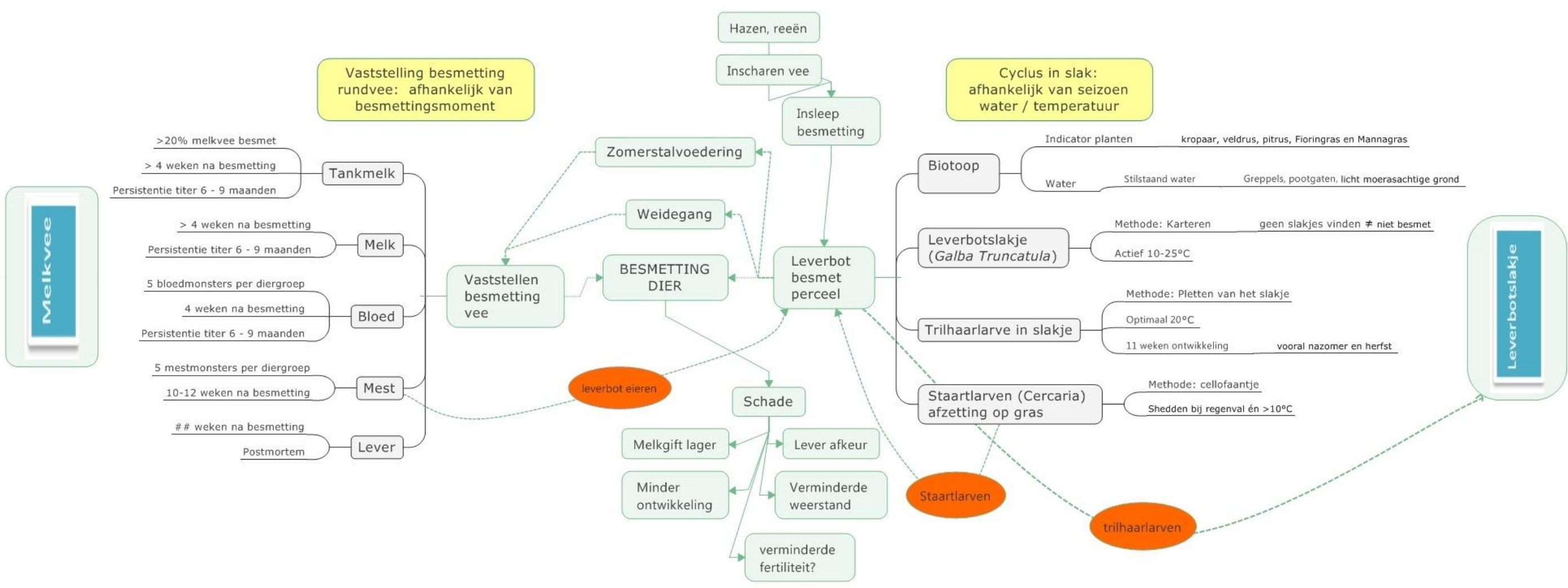

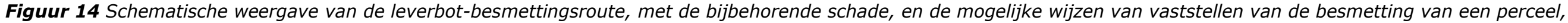
de slak en het dier 


\subsection{Maatregelen ter voorkoming van leverbotbesmetting}

Maatregelen ter voorkoming van een leverbotbesmetting zijn te verdelen in het 'ingrijpen' in de habitat van de slak, het verwijderen van de slak, het voorkomen van 'contact' met de slak en het voorkomen van insleep van de besmetting. Een aantal van deze maatregelen die uitgetest zijn en succesvol kunnen zijn worden hieronder kort weergegeven.

\subsubsection{Zomerfrezen}

Zomerfrezen lijkt een veelbelovende en eenvoudig toepasbare maatregel. Het frezen van de greppels in de zomer kan de leverbotbesmetting verminderen en vertragen. Door het uitfrezen van de greppels in de zomer decimeert de leverbotslakkenpopulatie tijdens droogte. Gelijktijdig creëert men droge greppels, de omstandigheden waaronder de slakken slecht gedijen. In de zomer gefreesde greppels resulteren mogelijk ook in "harde" greppels die koeien slechter vertrappen. Het gevolg is een betere waterafvoer in het najaar wat eveneens bijdraagt aan het beperken van de groei van de slakkenpopulatie en verminderen van de kans op leverbotbesmetting dan wel het vertragen van de opname naar later in het najaar. Zomerfrezen in combinatie met opstallen voor besmettingsafzetting op het gras in het najaar kan een leverbotbesmetting in het najaar zelfs voorkomen.

\subsubsection{Ontwijkend beweiden op basis van "uitrasteren"}

Het ontwijkend beweiden door mogelijk besmet gras uit te rasteren lijkt een effectieve en toepasbare maatregel om het aantal besmette dieren aanzienlijk te verminderen. Besmettingsontwijkend weiden kan via het afzetten van greppels, natte plekken en slootkanten met schrikdraad. Hetzelfde geldt voor zomerstalvoedering van veilig gras door geen vers gras op stal te voeren wat groeit langs greppels, op natte plekken of langs slootkanten. Het voorkomen van besmettingsopname via zomerstalvoedering door uitsluitend veilig gras te maaien is eenvoudig realiseerbaar. Potentieel met leverbot besmet gras kan men inkuilen.

\subsubsection{Aanvoer, jongvee opfok en inscharen}

Runderen, schapen, geiten en paarden afkomstig uit leverbotgebieden kunnen leverbot meebrengen bij aanvoer, terugkeer en/of inscharen op de eigen bedrijfspercelen. Insleep van leverbot op de eigen bedrijfspercelen via nieuwe aangevoerde dieren, via terugkerend vee dat elders is geweid en via het inscharen van vee van derden moet voorkomen worden. Onder de terugkeer op het eigen bedrijf vallen de uitbestede jongveeopfok en het uitscharen van eigen vee op percelen van derden. Runderen, schapen, geiten en paarden afkomstig uit gebieden die vrij zijn van leverbot vormen geen risico. Als nieuw aangevoerd, terugkerend of ingeschaard vee (mogelijk) heeft geweid op leverbotgevoelige percelen kan men met de juiste quarantaine maatregelen insleep van leverbot voorkomen. Ze mogen geen kans krijgen om meegebrachte leverboteieren op de bedrijfspercelen die leverbotgevoelig zijn uit te scheiden. Mestonderzoek op tien dagen na behandelen is vereist om vast te stellen of de behandeling tegen leverbot voldoende effectief is geweest.

\subsubsection{Preventieve maatregelen algemeen}

Bedrijven die meer dan één preventieve maatregel (quarantaine, een plan van aanpak, zomerstalvoedering, drainage, actieve ontwatering van leverbotgevoelige percelen, aangepast slootkantbeheer en weerstandsverhoging) nemen, lijken minder vaak besmet met leverbot. 


\section{$7 \quad$ Discussie en conclusie}

Vanuit de geraadpleegde literatuur, de inzet van het leverbotinstrument en het uitproberen van mogelijke preventieve maatregelen op drie bedrijven volgt hier een discussie, met aansluitend conclusies over de resultaten, waaronder de schade veroorzaakt door leverbot, het risico op besmetting, het vaststellen van een besmetting en de toe te passen preventieve maatregelen. Dit hoofdstuk wordt afgesloten met de aandachtspunten en de aanbevelingen voorkomend uit dit project.

\subsection{Schade}

De literatuur geeft aan dat leverbot schade kan veroorzaken waaronder een lagere melkopbrengst, minder en/of een vertraagde ontwikkeling van het jongvee, afgekeurde levers, slechtere vruchtbaarheid en verminderde weerstand. Sterfte van runderen door leverbot is zeldzaam. Bij schapen echter kan leverbot zowel acute en chronische sterfte veroorzaken. In de interviews met de 25 bedrijven wordt schade door leverbot sporadisch genoemd. In de data-analyse zijn wel enkele aanwijzingen gevonden.

\subsubsection{Melkgift}

De literatuur geeft aan dat met leverbot besmette melkkoeien een verminderde melkgift hebben. In dit onderzoek hebben we geen verschil in gemiddelde melkgift per koe per jaar gevonden tussen de leverbot positieve- en negatieve bedrijven.

\subsubsection{Fertiliteit}

De literatuur is niet eenduidig over mogelijke effecten van leverbot op de fertiliteit van runderen. In dit onderzoek is daarvoor ook geen indicatie gevonden o.b.v. aantal inseminaties. De factoren die een rol kunnen spelen bij het wel of niet vinden van effecten op fertiliteit zijn de weerstand bij het rund tegen leverbot en een (jarenlange) selectie op bedrijfsniveau. De bekende weerstandsresponsen zijn de verkalking van de galgangen (fysieke belemmering), de levensduur van leverbot in het rund van één jaar, de antistoffen, een beperkte aantasting van de lever en de herstelcapaciteit van de lever na aantasting. Ook zou de gezond blijvende helft van de lever van het rund kunnen bijdragen aan het voorkomen van vruchtbaarheidsstoornissen door leverbot.

\subsubsection{Sterfte}

De literatuur geeft aan dat sterfte zelden voorkomt bij runderen. Sterfte in het algemeen kwam in dit onderzoek onder de melkkoeien wel vaker voor op leverbot positieve bedrijven. Mede omdat het epidemiologisch onderzoek betreft kon niet worden vastgesteld dat leverbot daar aan ten grondslag lag of dat dat voor rekening komt van andere kenmerkende (regio of bedrijfs)verschillen. Sterfte van kalveren was in dit onderzoek niet gerelateerd aan leverbot. Aannemelijk is dat een leverbotinfectie vooral bij jongvee kan leiden tot een verminderde weerstand.

\subsubsection{Salmonella}

De literatuur geeft aan dat bedrijven die besmet zijn met leverbot gevoeliger zijn voor andere (bacteriële) infecties zoals Salmonella doordat de dieren een verminderde weerstand hebben. In dit onderzoek hebben wij geen verband kunnen leggen tussen het voorkomen van Salmonella en leverbotbesmettingen.

\subsubsection{Algemeen onderzoeksbeeld}

Zoals hierboven beschreven staat, benoemen en/of signaleren de bedrijven in dit onderzoek schade, inclusief sterfte, door leverbot niet of nauwelijks en is er ook geen verschil uit de analyse van de data

50 | Wageningen Livestock Research, Louis Bolk Instituut, rapport 1029 
gekomen, terwijl de literatuur wel degelijk schade beschrijft door leverbotinfecties. Met name het niet benoemen van een verminderde melkopbrengst valt op. Verklaringen hiervoor kunnen zijn:

i. Er daadwerkelijk sprake is van geen of minimale schade door een te geringe omvang van de besmetting. Dit sluit aan bij de GD-veronderstelling dat bij runderen de ziekte vaak sluimerend aanwezig is zonder duidelijke ziekteverschijnselen

ii. De schade niet is opgemerkt ondanks dat sprake is geweest van forse besmettingen. Een kwestie van niet signaleren kan doordat de veehouder geen verschil ziet in zijn productieniveaus, omdat hij het productieniveau van de dieren niet kent als zij vrij zijn van een leverbotbesmetting. Of eenvoudigweg omdat de veehouder fluctuaties in productieniveaus door wisselende besmettingsdruk niet opmerkt.

iii. Er daadwerkelijk sprake is van geen of minimale schade omdat de lever van de runderen over voldoende overcapaciteit beschikt om de negatieve gevolgen van een besmetting te minimaliseren.

iv. Er geen sprake is geweest van een ernstig leverbotjaar. Dit laatste ligt weinig voor de hand omdat 1) het interview zich niet heeft beperkt tot 2015 met de vragen over schade en 2) bedrijven zijn geselecteerd in leverbotgevoelige gebieden.

v. Er is sprake van geringe schade doordat de runderpopulatie op bedrijven in de traditionele leverbotgebieden waarschijnlijk is geselecteerd naar een 'robuuste' populatie die minder gevoelig is voor leverbot c.q. met een hogere genetische weerstand.

vi. Het niet vinden van verschillen in schade tussen wel en niet met leverbot besmette bedrijven kan deels ook liggen in het feit dat maar een klein aantal bedrijven opgenomen is in de analyse.

\subsection{Risico op besmetting}

Veranderingen in het klimaat (intensiteit extreme neerslag, verhoging van de temperatuur) en de vernatting van gebieden ten behoeve van de natuur en weidevogels zou (een deel van de) toename van (de mate van) besmette gebieden kunnen veroorzaken. Maar binnen het leverbotgevoelige gebied in Nederland komen nog steeds bedrijven voor die niet besmet zijn. Daarnaast kan ook het aandeel besmette dieren binnen een besmet bedrijf verschillen, wat vooral veroorzaakt wordt door verschil in blootstelling van de verschillende diercategorieën aan leverbot. In dit onderzoek was het jongvee op drie bedrijven positief voor leverbot en het melkvee negatief. Op het gebied van perceelsituatie en beweiding zien we in dit onderzoek dat op bedrijven waarvan het jongvee leverbot positief is een hoger percentage percelen waar regelmatig/langere tijd water in de greppels staat. Het is opmerkelijk dat op de positieve bedrijven in minder gevallen water op de percelen blijft staan. Dit is echter ook gevonden door Selemetas et al. (2015b).

Naast de verschillen in beweiding en perceelsverschillen heeft ook de manier waarop de veehouders omgaan met infectierisico invloed op de besmettingsgraad. Zo is insleep van infectie mogelijk via aangekocht besmet vee of wild (reeën en hazen) en levert het weiden in natte gebieden een hoger risico op. Binnen dit onderzoek zagen we echter geen verschil in de gemiddelde kennisscore die een veehouder heeft op positieve en negatieve bedrijven. Wel waren op alle negatieve bedrijven de veehouders op de hoogte van de leverbotprognose in hun gebied en weten zij welke factoren een rol spelen bij de opbouw van een besmetting. Bij de positieve bedrijven was dat niet het geval.

Ook de inzet van preventieve maatregelen kan verklaren waarom er bedrijven zijn die vrij zijn van leverbot ondanks dat zij zich bevinden in het leverbotgevoelige gebied. Op de negatieve bedrijven worden significant meer preventieve maatregelen getroffen dan op de positieve bedrijven. Het gaat dan om de preventieve maatregelen als zomerstalvoedering, een aangepast beweidingsplan om besmetting ontwijkend te beweiden, weerstand verhogen van het vee, aangepast slootkantbeheer en actieve ontwatering indien nodig.

\subsection{Vaststelling besmetting}

Een onderdeel van het hebben van kennis over de mate waarin het bedrijf risico loopt op een besmetting, is het zicht hebben op en het daadwerkelijk laten controleren op een besmetting. In dit onderzoek was het merendeel van de deelnemers niet op de hoogte van de leverbotstatus van hun 
bedrijf. Op vier van de zeven (actueel) positieve bedrijven vermoedde de veehouder geen actuele besmetting.

In dit onderzoek hebben we naast een eerste screening via tankmelk ook bloedonderzoek laten uitvoeren op de vier verschillende diercategorieën. De uitslagen van het bloedonderzoek gaf voor sommige bedrijven een discrepantie in besmetting tussen het melkvee en jongvee. Op drie bedrijven was het jongvee positief voor leverbot en het melkvee negatief. Op acht bedrijven was dit andersom; jongvee negatief en melkvee positief. De tankmelk gecombineerd laten testen op maagdarmwormenen leverbotte vroeg in het najaar (september/oktober/november), levert voor leverbot nogal eens onterecht negatieve uitslagen op. Dit vormt een belangrijke verklaring voor de onverwacht positieve uitslagen bij de vorming van de matches (zie paragraaf 4.1.1). De tankmelkuitslag zegt niets over de andere aanwezige groepen dieren op het bedrijf en een positieve uitslag laat zich voorts niet altijd eenvoudig differentiëren naar de besmette groep runderen. Daarvoor is individuele melk- of bloedbemonstering nodig.

Terugkoppeling van de reden waarom de lever is afgekeurd, geeft de veehouder informatie over de leverbothistorie van zijn geslachte dieren. Een beperking van deze post mortem methode van vaststellen van een infectie is dat dit vaak geen zicht geeft op de actualiteit van de besmetting op het melkveebedrijf (zie ook paragraaf 6.2.2). Hoe meer slachtingen, hoe betrouwbaarder de indicatie van de besmettingsgraad.

Daarnaast bleek gedurende dit onderzoek dat het karteren, het al of niet vinden van het leverbotslakje, niet een $100 \%$ waterdichte methode is om de besmetting vast te stellen op een perceel.

\subsection{Behandeling}

Goed behandelen van het met leverbot besmette jongvee is belangrijk, omdat niet goed behandelde dieren de cyclus van de leverbot in stand kunnen houden doordat ze in het voorjaar niet vrij van leverbot weer de weide op gaan. In dit onderzoek is dat het geval op bijna alle bedrijven waarvan het jongvee positief is. Ook is in dit onderzoek naar voren gekomen dat op geen enkel bedrijf via mestonderzoek wordt vastgesteld of de behandeling effect heeft. De totaalscore die het risico op fout behandelen aangeeft ligt in dit onderzoek drie keer hoger op de positieve bedrijven dan op de negatieve bedrijven. Goed behandelen is een aandachtspunt.

Lacterende dieren mogen niet worden behandeld tegen leverbot (alleen onder de cascaderegeling). Het is niet te verwachten dat nieuwe diergeneesmiddelen tegen leverbot op (korte of middellange) termijn op de markt zullen komen. Een klein lichtpuntje is dat op dit moment een aantal onderzoeken lopen naar de ontwikkeling van een vaccin tegen leverbot (Dalton et al., 2013; Molina-Hernández et al., 2015; Toet et al., 2014).

\subsection{Conclusie vanuit de uitgeprobeerde preventieve maatregelen}

\subsubsection{Karteren}

Een perceel kan gevoelig zijn, maar hoeft dan nog niet besmet te zijn. Andersom als vee besmet is geraakt op een bepaald perceel was het perceel ook gevoelig en hoef je niet meer te karteren! Deze deductie is simpeler en goedkoper. Wanneer een perceel gevoelig is, berust het niet besmet raken meer op toeval. Dit toeval bestaat uit het afzetmoment van de besmetting onder invloed van de weersomstandigheden en de beweiding. Anders gezegd, als je weet dat een perceel leverbotgevoelig is, kan het vee er een voorjaarsbesmetting of najaarsbesmetting oppikken. Wil je dat voorkomen moet je daar dan niet komen met (jong)vee.

\subsubsection{Zomerfrezen}

Zomerfrezen lijkt een veelbelovende en eenvoudig toepasbare maatregel om leverbotbesmetting te voorkomen (zie paragraaf 6.4.1). De effectiviteit van de maatregel is weersafhankelijk. Door bij 
droogte vroeg in het weideseizoen te starten en de greppels van gemaaide percelen te frezen kan men het slakdodend effect bedrijfsbreed maximaliseren. Geef bij keuze prioriteit aan de meest leverbotgevoelige percelen. Zomerfrezen na weiden en bloten geeft waarschijnlijk ook het gewenste effect, namelijk het decimeren van de slakkenpopulatie. Deze maatregel kost geen extra arbeid als de zomergefreesde greppels goed uitharden en zo ook in het najaar nog voldoende afwateren.

\subsubsection{Ontwijkend beweiden en maaien}

Het ontwijkend beweiden door mogelijk besmet gras uit te rasteren lijkt een effectief toepasbare maatregel om het aantal besmette dieren aanzienlijk te verminderen (zie paragraaf 6.4.2). Hetzelfde geldt voor zomerstalvoedering als men mogelijk besmet gras niet vers voert maar inkuilt of hooit (zie ook paragrafen 4.3.2 en 6.4.2). Deze maatregel verlaagt de besmettingsdruk op de melkveepercelen en buitenstukken aanzienlijk doordat de constante, jaarlijkse besmettingsaanvoer vanuit het onbehandeld blijven van de lacterende en droge koeien een steeds kleiner deel bijdraagt aan de totale besmettingsdruk op een perceel. Behandelen in combinatie met ontwijkend beweiden en maaien versnelt de afname van de besmettingsdruk. Behandelen van lacterende runderen en droogstaande runderen is echter niet mogelijk. Men kan echter, maar dan alleen onder de cascaderegeling, met een eenmalige behandeling van de melkkoeien tijdens de stalperiode de hele besmettingsaanvoer vanuit het melkvee in het voorjaar op leverbotgevoelige percelen wegnemen en daarvan ook de jaren erna profiteren. In geval van een zwaar besmette melkveestapel valt dit te overwegen.

\subsection{Aandachtspunten}

- De leverbot prevalentie in Nederland is onbekend. Het percentage leverbot positieve bedrijven uit het jaarlijkse 'Worminfecties Tankmelk' onderzoek van de Gezondheidsdienst is gebaseerd op een vrijwillige deelname van bedrijven. Voor de status van een mogelijke leverbotinfectie vindt dit onderzoek niet altijd plaats in de juiste periode van het jaar (vier weken na opstallen).

- Karteren is niet zomaar te doen. Op twee bedrijven is naar slakken gezocht en zijn ze niet gevonden terwijl later bleek, op basis van positieve runderen, dat ze er wel moeten hebben gezeten. Het moment in het jaar en de aan het moment gerelateerde populatie-omvangsdynamiek én ontwikkelstadium waarin de slak verkeert zijn sterk bepalend voor de vindbaarheid. Augustus en september zijn lastige vindmaanden vanwege de dan vaak voorkomende droogte. En afhankelijk van het weer en het ontwikkelstadium kan het daarom ook in oktober nog lastig zijn om volwassen slakjes te vinden. Er is dus meer kennis nodig van de Galba truncatula om de kans op het vinden van de slakjes in gebieden waar ze voorkomen te vinden. Het niet vinden van die slakjes blijkt nu geen garantie voor geen besmetting van het betreffende perceel te zijn. Op een betrouwbare manier karteren lijkt vooralsnog voorbehouden aan specialisten.

- Het is niet ondenkbaar dat andere slakkensoorten tussengastheer zijn van de leverbot in het onderzochte gebied, zoals in buitenlands onderzoek is gevonden. Naast de Galba truncatula zouden ook andere slakjes in Nederland besmet kunnen zijn zoals de Radix balthica en Radix labiata gezien het onderzoek in onder andere België.

- Pensbot kan tegelijk voorkomen met leverbot. Pensbot zou in Nederland in redelijke mate aanwezig kunnen zijn, waarbij co-infectie met leverbot voor kan komen, gezien het onderzoek in ons omringende landen. Het aantal bedrijven of koeien dat daadwerkelijk besmet is met pensbot in Nederland is onbekend.

- Het effect van drainage op de leverbotgevoeligheid van de percelen is (nog) niet duidelijk.

- Effectieve maatregelen om de weerstand tegen leverbotziekte te verhogen (zoals een voederadditief of vaccin) ontbreken nog.

- Behalve het zomerfrezen van de greppels zijn andere praktische toepasbare methoden om de tussengastheer te doden en daarmee de cyclus van leverbot te doorbreken én de besmettingsopbouw in het seizoen te voorkomen, vooralsnog niet beschikbaar.

- Behandelen van lacterend melkvee, of vee dat droogstaat maar al lacterend is geweest is alleen mogelijk onder de cascaderegeling. Echter wordt vaak niet de cyclus op het bedrijf doorbroken als alleen deze dieren worden behandelt en geen andere maatregelen worden genomen. 


\subsection{Praktische aanbevelingen}

Leverbot kan leiden tot aanzienlijke economische schade en is een veel voorkomend probleem op melkveebedrijven, omdat weidepercelen de habitat kunnen vormen voor de tussengastheer, het leverbotslakje. Door gebrek aan geregistreerde diergeneesmiddelen voor melkgevende dieren is het van belang om inzicht te hebben in de leverbotstatus van uw bedrijf en met behulp van preventieve maatregelen infecties te voorkomen. Hiertoe doen wij de volgende aanbevelingen;

\section{Gebruik het leverbotinstrument}

- Het leverbotinstrument helpt de groepen dieren (kalveren, pinken, drachtige vaarzen, droge koeien, nieuwmelkte- en oudmelkte koeien, schapen en lammeren) die risico lopen op een leverbotbesmetting te identificeren

- Het leverbotinstrument helpt de risicofactoren op een leverbotbesmetting in kaart te brengen.

- Het leverbotinstrument helpt bij het identificeren van mogelijke preventieve maatregelen

II. Bepaal (of laat bepalen) de leverbotgevoeligheid van uw percelen

- Bepaal de biotoop van uw percelen door te inventariseren of er waterlichamen (plassen, poelen, natte greppels, drassige slootkant) of indicatorplanten voor het leverbotslakje aanwezig zijn

- Laat uw percelen door een expert karteren op de aanwezigheid van het leverbotslakje

III. Bepaal (of laat bepalen) of een perceel besmet is

- Laat de bij het karteren gevonden slakken controleren op de aanwezigheid van de leverbottrilhaarlarve

- Ga na of er afzetting van cercaria heeft plaatsgevonden (door middel van het plaatsen van cellofaantje in waterlichaam)

IV. Bepaal de leverbotstatus van uw bedrijf

- Om de infectiestatus van uw totale bedrijf te bepalen, wordt aangeraden om binnen specifieke groepen dieren van vijf dieren per groep de status te bepalen. Deze groepen kunt u m.b.v. het leverbotinstrument identificeren. De status kan bepaald worden uit leverbotantistoffen uit melk en bloed vanaf vier weken na opstallen

- Laat de tankmelk vanaf vier weken na opstallen controleren op leverbotantistoffen. Op deze manier krijgt u een indruk van de mogelijke mate van besmetting van uw melkgevend vee

- Laat een mengmonster mest van vijf dieren vanaf twaalf weken na opstallen op de aanwezigheid van leverboteieren controleren. Dit geeft een goede afspiegeling van de prevalentie van afweerstoffen in het bloed van de dieren die op dezelfde manier geweid zijn

- De status van de verschillende diergroepen kan in combinatie met de beweidingsinformatie helpen een besmetting toe te wijzen aan leverbotgevoelige percelen en deze aan te merken als leverbotgevoelig of leverbotongevoelig. Uitslagen van onderzoek naar leverbotantistoffen kan ook de introductieroute van een leverbotbesmetting op het bedrijf blootleggen. Het testen op leverbotantistoffen op groepsniveau draagt zodoende bij aan een meer gerichte aanpak van de leverbotproblematiek en het formuleren van effectieve maatregelen ter preventie of minimalisering van leverbot op het bedrijf

\section{Vraag om een terugkoppeling van de leverbeoordeling in het slachthuis}

- Slachtinformatie over afkeur van de lever kan aanleiding zijn tot behandeling (mits toegestaan) van de dieren met dezelfde beweidingshistorie als de diagnose vermeld dat er levende botten zijn aangetroffen

- In geval een lever wordt afgekeurd vanwege oud littekenweefsel (verkalkte galggangen, driehoekslevers) geeft de slachtterugkoppeling geen inzicht in de huidige leverbotstatus

vI. Behandel dieren indien nodig en toegestaan

- Behandel besmet jongvee pas vanaf twee weken na opstallen met een middel met als werkzame stof triclabendazol, mits er op het bedrijf geen resistentie bestaat tegen deze werkzame stof

- Behandel bij een flinke besmetting van het melkgevende vee, in overleg met de dierenarts en binnen de cascaderegeling, het gehele melkkoppel vanaf twee weken na opstallen met een middel met als werkzame stof triclabendazol, mits er op het bedrijf geen resistentie bestaat tegen deze werkzame stof

- Controleer via mestonderzoek of de behandeling effect heeft gehad

vII. Voorkom een leverbotbesmetting

- $\quad$ Raster waterlichamen (zoals drassige slootkanten, plassen, poelen of natte greppels) uit

- Ontwijk percelen met waterlichamen in de risicomaanden. Laat een expert in kaart brengen welke percelen risicopercelen zijn en welke percelen gebruikt kunnen worden om ontwijkend te beweiden tijdens de risicomaanden 
- $\quad$ Frees de greppels bij drogend weer (zomer). Door de droogte drogen de op het land geslingerde slakken uit. In de zomer gefreesde greppels resulteren mogelijk ook in "harde" greppels die het vee slechter vertrapt en die een betere waterafvoer behouden

- Stal uw dieren in het najaar op voordat de afzetting van besmetting op het gras (cercaria) heeft plaatsgevonden

- Gebruik bij (zomer)stalvoedering alleen veilig gras (dus geen gras van leverbot besmette percelen of gras naast waterlichamen)

- Voorkom insleep van leverbot op de eigen bedrijfspercelen via nieuwe aangevoerde dieren, via terugkerend vee dat elders is geweid en via het inscharen van vee van derden. Onder de terugkeer op het eigen bedrijf vallen de uitbestede jongveeopfok en het uitscharen van eigen vee op percelen van derden. Runderen, schapen, geiten en paarden afkomstig uit leverbotgebieden kunnen leverbot meebrengen.

- $\quad$ Pas de juiste quarantaine maatregelen toe als nieuw aangevoerd, terugkerend of ingeschaard vee (mogelijk) heeft geweid op leverbotgevoelige percelen. Mestonderzoek op tien dagen na behandelen is vereist om vast te stellen of de behandeling tegen leverbot voldoende effectief is geweest

\section{Plan van aanpak}

- $\quad$ Stel een eigen plan van aanpak op met een expert om leverbotbesmetting te voorkomen op uw bedrijf. Bedrijven die meer dan één preventieve maatregel (quarantaine, een plan van aanpak, zomerstalvoedering, drainage, actieve ontwatering van leverbotgevoelige percelen, aangepast slootkantbeheer en weerstandsverhoging) nemen, lijken minder vaak besmet met leverbot 


\section{$8 \quad$ Verschenen publicaties en gehouden bijeenkomsten over dit onderzoek}

- $\quad$ Neijenhuis, F., Verkaik, J., Verwer, C., Smolders, G., en J.P. Wagenaar (2014). Integrale diergezondheid: beheersing van leverbot. Livestock Research Rapport 807, 39p.

- Neijenhuis, F., Verkaik, J., Verwer, C., Wagenaar, J.P., Smolders, G. en B. Van der Hoog (2015) Leverbot in kaart gebracht. Leverbotinfecties herkennen, genezen en voorkomen. Ekoland

- Verkaik, J., en C. Verwer (2015) Leverbot in kaart gebracht. V-Focus. Juni 2015, p. 27-29.

- Verwer, C., Neijenhuis, F. en J. Verkaik (2015). Leverbot project. Natuurweidekrant: p. 2-3

- Wagenaar, J. (2015) Leverbot in kaart gebracht: leverbotinfecties herkennen, genezen en voorkomen. Ekoland. Maart 2015, p. 24-25.

- $\quad$ Alternatieve bestrijding van leverbot, interview met Judith van Andel (Provinos) en Cynthia Verwer (Louis Bolk Instituut) door Henk ten Have, Veearts. Februari 2016 en www.veearts.nl

- Verwer, C., Verkaik, J. en F. Neijenhuis (2017) Risico's en kansen leverbotbestrijding op uw bedrijf. Deel I: Instrument voor bedrijfsanalyse op risicofactoren. Ekoland.

- Verkaik, J,. Verwer, C. en Neijenhuis, F. (2017) Risico's en kansen leverbotbestrijding op uw bedrijf. Deel II: Vang slak in plaats van bot. Ekoland.

- Haveman, E. (2015). Alternatieve maatregelen tegen Leverbot (Onderzoeksrapport). Stageverslag. InHolland Hogeschool: $62 \mathrm{p}$.

- Kennis- en onderzoeksagenda leverbot, Leverbot expertmeeting (2015) O.a. verschenen op www.verantwoordeveehouderij.nl, www.plattelandspost.nl, www.veearts.nl

- Projectpagina Leverbot Wageningen Livestock Research, www.wur.nl/nl/project/Integralediergezondheid-beheersing-van-leverbot

- Projectpagina Leverbot, http://www.louisbolk.org/nl/landbouw/dierenwelzijn/praktijkonderzoekleverbot

- Leverbotbijeenkomst op VIC te Zegveld voor veehouders, stand van zaken m.b.t. leverbotprojecten, juni 2015

- $\quad$ Expertmeeting leverbot te Deventer, maart 2015

- $\quad$ Studiegroep Midden-Delfland, 2 bijeenkomsten in 2015 
Armstrong, D. (2014). Liver fluke in cattle - costs and control. In Engeland: Pfizer Animal Health.

Athanasiadou, S., Arsenos, G. and Kyriazakis, I. (2002). Animal health and welfare issues arising in organic ruminant production systems. In Organic meat and milk from ruminants (ed. Zervas, K. I. G.), pp. 35-56. Wageningen Academic Publishers, Wageningen.

Bennema, S., Vercruysse, J., Claerebout, E., Schnieder, T., Strube, C., Ducheyne, E., Hendrickx, G. and Charlier, J. (2009). The use of bulk-tank milk ELISAs to assess the spatial distribution of Fasciola hepatica, Ostertagia ostertagi and Dictyocaulus viviparus in dairy cattle in Flanders (Belgium). Veterinary Parasitology, 165, 51-57. doi: http://dx.doi.org/10.1016/j.vetpar.2009.07.006.

Bennema, S. C., Ducheyne, E., Vercruysse, J., Claerebout, E., Hendrickx, G. and Charlier, J. (2011). Relative importance of management, meteorological and environmental factors in the spatial distribution of Fasciola hepatica in dairy cattle in a temperate climate zone. International Journal for Parasitology, 41, 225-233. doi: http://dx.doi.org/10.1016/j.ijpara.2010.09.003.

Boray, J. (2015). Fluke costs more than $\$ 100$ million. The FlukeKill programme increases production. Virbac Animal Health.

Borgsteede, F. H. M. (2011). Diseases of Dairy Animals | Parasites, Internal: Liver Flukes. In Encyclopedia of Dairy Sciences (Second Edition) (ed. Fuquay, J. W.), pp. 264-269. Academic Press, San Diego.

Byrne, A. W., McBride, S., Lahuerta-Marin, A., Guelbenzu, M., McNair, J., Skuce, R. A. and McDowell, S. W. J. (2016). Liver fluke (Fasciola hepatica) infection in cattle in Northern Ireland: a large-scale epidemiological investigation utilising surveillance data. Parasites \& Vectors, 9, 1-14. doi: http://dx.doi.org/10.1186/s13071-016-1489-2.

Caron, Y., Lasri, S. and Losson, B. (2007). Fasciola hepatica: An assessment on the vectorial capacity of Radix labiata and R. balthica commonly found in Belgium. Veterinary Parasitology, 149, 95-103. doi: http://dx.doi.org/10.1016/j.vetpar.2007.07.012.

Caron, Y., Martens, K., Lempereur, L., Saegerman, C. and Losson, B. (2014). New insight in lymnaeid snails (Mollusca, Gastropoda) as intermediate hosts of Fasciola hepatica (Trematoda, Digenea) in Belgium and Luxembourg. Parasites \& Vectors, 7. doi: http://dx.doi.org/10.1186/1756-3305-7-66.

Charlier, J., De Meulemeester, L., Claerebout, E., Williams, D. and Vercruysse, J. (2008). Qualitative and quantitative evaluation of coprological and serological techniques for the diagnosis of fasciolosis in cattle. Veterinary Parasitology, 153, 44-51. doi: http://dx.doi.org/10.1016/j.vetpar.2008.01.035.

Charlier, J., Soenen, K., De Roeck, E., Hantson, W., Ducheyne, E., Van Coillie, F., De Wulf, R., Hendrickx, G. and Vercruysse, J. (2014). Longitudinal study on the temporal and micro-spatial distribution of Galba truncatula in four farms in Belgium as a base for small-scale risk mapping of Fasciola hepatica. Parasites \& Vectors, 7. doi: http://dx.doi.org/10.1186/s13071-014-0528-0.

Dalton, J. P., Robinson, M. W., Mulcahy, G., O'Neill, S. M. and Donnelly, S. (2013). Immunomodulatory molecules of Fasciola hepatica: Candidates for both vaccine and immunotherapeutic development. Veterinary Parasitology, 195, 272-285. doi: http://dx.doi.org/10.1016/j.vetpar.2013.04.008.

Dobbs, M. (2013). Challenges in fluke control. Veterinary Times, 13.

Dobbs, M. (2014). Managing liver fluke in cattle and sheep, whatever the weather. Veterinary Times.

Ducheyne, E., Charlier, J., Vercruysse, J., Rinaldi, L., Biggeri, A., Demeler, J., Brandt, C., Waal, T., Selemetas, N., Höglund, J. and Kaba, J. (2015). Modelling the spatial distribution of Fasciola hepatica in dairy cattle in Europe. Geospatial Health, 9, 261-270. doi: http://dx.doi.org/10.4081/gh.2015.348.

Duscher, R., Duscher, G., Hofer, J., Tichy, A., Prosl, H. and Joachim, A. (2011). Fasciola hepatica Monitoring the milky way? The use of tank milk for liver fluke monitoring in dairy herds as base for treatment strategies. Veterinary Parasitology, 178, 273-278. doi: http://dx.doi.org/10.1016/j.vetpar.2011.01.040.

Fairweather, I. (2011). Reducing the future threat from (liver) fluke: realistic prospect or quixotic fantasy? Veterinary Parasitology, 180, 133-143. doi: http://dx.doi.org/10.1016/j.vetpar.2011.05.034.

Ferreira, M. (2012). Liver fluke on the increase in South Africa. Farmers Weekly, 12.

Fitzpatrick, J. L. (2013). Global food security: The impact of veterinary parasites and parasitologists. Veterinary Parasitology, 195, 233-248. doi: http://dx.doi.org/10.1016/j.vetpar.2013.04.005. 
Fox, N. J., Marion, G., Davidson, R. S., White, P. C. L. and Hutchings, M. R. (2015). Climate-driven tipping-points could lead to sudden, high-intensity parasite outbreaks. Royal Society Open Science, 2. doi: http://dx.doi.org/10.1098/rsos.140296.

Fox, N. J., White, P. C. L., McClean, C. J., Marion, G., Evans, A. and Hutchings, M. R. (2011). Predicting Impacts of Climate Change on Fasciola hepatica Risk. PLoS ONE, 6, e16126. doi: http://dx.doi.org/10.1371/journal.pone.0016126.

Gaasenbeek, C. P. H., Over, H. J., Noorman, N. and de Leeuw, W. A. (1992). An epidemiological study of Fasciola hepatica in the Netherlands. Veterinary Quarterly, 14, 140-144. doi: http://dx.doi.org/10.1080/01652176.1992.9694351.

GD (z.j.-a). Aanpak leverbot op melkveebedrijven met een salmonella-infectie (1504-08-12) (ed. Gezondheidsdienst voor Dieren).

GD (z.j.-b). GD Tankmelk Leverbot. Groeiend probleem vraagt om consequente monitoring. (ed. Gezondheidsdienst voor Dieren).

GD (z.j.-c). Leverbot. (ed. Gezondheidsdienst voor Dieren).

Hourdin, P., Vignoles, P., Dreyfuss, G. and Rondelaud, D. (2006). Galba truncatula (Gastropoda, Lymnaeidae): effects of daily waterlevel variations on the ecology and ethology of populations living upstream from a dam. Annales de Limnologie - International Journal of Limnology, 42, 173-180. doi: http://dx.doi.org/10.1051/limn/2006018.

Howell, A., Baylis, M., Smith, R., Pinchbeck, G. and Williams, D. (2015). Epidemiology and impact of Fasciola hepatica exposure in high-yielding dairy herds. Preventive Veterinary Medicine, 121, 41 48. doi: http://dx.doi.org/10.1016/j.prevetmed.2015.05.013.

Hutchinson, G. W. and Macarthur, E. (2003). Validation of French Anti-body ELISA for Liver Fluke Meat \& Livestock Australia Limited ABN 39081678364 (MLA), North Sydney.

Kaplan, R. (2001). Fasciola hepatica: A Review of the Economic Impact in Cattle and Considerations for Control. Veterinary Therapeutics, 2, 40-50.

Kelley, J. M., Elliott, T. P., Beddoe, T., Anderson, G., Skuce, P. and Spithill, T. W. (2016). Current Threat of Triclabendazole Resistance in Fasciola hepatica. Trends in Parasitology, 32, 458-469. doi: http://dx.doi.org/10.1016/j.pt.2016.03.002.

Knubben-Schweizer, G., Rüegg, S., Torgerson, P. R., Rapsch, C., Grimm, F., Hässig, M., Deplazes, P. and Braun, U. (2010). Control of bovine fasciolosisin dairy cattle in Switzerland with emphasis on pasture management. The veterinary journal, 186, 188-191.

Knubben-Schweizer, G. and Torgerson, P. R. (2015). Bovine fasciolosis: Control strategies based on the location of Galba truncatula habitats on farms. Veterinary Parasitology, 208, 77-83. doi: http://dx.doi.org/10.1016/j.vetpar.2014.12.019.

Kuerpick, B., Conraths, F. J., Staubach, C., FröHlich, A., Schnieder, T. and Strube, C. (2013). Seroprevalence and GIS-supported risk factor analysis of Fasciola hepatica infections in dairy herds in Germany. Parasitology, 140, 1051-1060. doi: 10.1017/s0031182013000395.

Mas-Coma, S., Valero, M. A. and Bargues, M. D. (2009). Chapter 2 Fasciola, Lymnaeids and Human Fascioliasis, with a Global Overview on Disease Transmission, Epidemiology, Evolutionary Genetics, Molecular Epidemiology and Control. Advances in Parasitology, 69, 41-146. doi: http://dx.doi.org/10.1016/S0065-308X(09)69002-3.

Mazeri, S., Sargison, N., Kelly, R. F., Bronsvoort, B. M. d. and Handel, I. (2016). Evaluation of the Performance of Five Diagnostic Tests for Fasciola hepatica Infection in Naturally Infected Cattle Using a Bayesian No Gold Standard Approach. PLOS ONE, 11, e0161621. doi: http://dx.doi.org/10.1371/journal.pone.0161621.

McCann, C. M., Baylis, M. and Williams, D. J. (2010). Seroprevalence and spatial distribution of Fasciola hepatica-infected dairy herds in England and Wales. Veterinary Record, 166, 612-617. doi: http://dx.doi.org/10.1136/vr.b4836.

Mezo, M., González-Warleta, M., Castro-Hermida, J. A., Muiño, L. and Ubeira, F. M. (2011). Association between anti-F. hepatica antibody levels in milk and production losses in dairy cows. Veterinary Parasitology, 180, 237-242. doi: http://dx.doi.org/10.1016/j.vetpar.2011.03.009.

Molina-Hernández, V., Mulcahy, G., Pérez, J., Martínez-Moreno, Á., Donnelly, S., O’Neill, S. M., Dalton, J. P. and Cwiklinski, K. (2015). Fasciola hepatica vaccine: We may not be there yet but we're on the right road. Veterinary Parasitology, 208, 101-111. doi: http://dx.doi.org/10.1016/j.vetpar.2015.01.004.

Naranjo Lucena, A., Garza Cuartero, L., Mulcahy, G. and Zintl, A. (2017). The immunoregulatory effects of co-infection with Fasciola hepatica: From bovine tuberculosis to Johne's disease. The veterinary journal, 222, 9-16. doi: http://dx.doi.org/10.1016/j.tvjl.2017.02.007.

Neijenhuis, F., Verkaik, J., Verwer, C., Smolders, G. and Wagenaar, J. P. (2014). Integrale diergezondheid: beheersing van leverbot. Livestock Research Rapport 807 
Olsen, A., Frankena, K., Bodker, R., Toft, N., Thamsborg, S. M., Enemark, H. L. and Halasa, T. (2015). Prevalence, risk factors and spatial analysis of liver fluke infections in Danish cattle herds. Parasites \& Vectors, 8, 160. doi: http://dx.doi.org/10.1186/s13071-015-0773-x.

Rapsch, C., Dahinden, T., Heinzmann, D., Torgerson, P. R., Braun, U., Deplazes, P., Hurni, L., Bar, H. and Knubben-Schweizer, G. (2008). An interactive map to assess the potential spread of Lymnaea truncatula and the free-living stages of Fasciola hepatica in Switzerland. Veterinary Parasitology, 154, 242-249. doi: 10.1016/j.vetpar.2008.03.030.

Rapsch, C., Schweizer, G., Grimm, F., Kohler, L., Bauer, C., Deplazes, P., Braun, U. and Torgerson, P. R. (2006). Estimating the true prevalence of Fasciola hepatica in cattle slaughtered in Switzerland in the absence of an absolute diagnostic test. International Journal for Parasitology, 36, 1153-1158. doi: http://dx.doi.org/10.1016/j.ijpara.2006.06.001.

Rondelaud, D., Hourdin, P., Vignoles, P., Dreyfuss, G. and Cabaret, J. (2011). The detection of snail host habitats in liver fluke infected farms by use of plant indicators. Veterinary Parasitology, 181, 166-173. doi: http://dx.doi.org/10.1016/j.vetpar.2011.03.056.

Rondelaud, D., Titi, A., Vignoles, P., Mekroud, A. and Dreyfuss, G. (2013). Consequence of temperature changes on cercarial shedding from Galba truncatula infected with Fasciola hepatica or Paramphistomum daubneyi. Parasite, 20, 10. doi: http://dx.doi.org/10.1051/parasite/2013009.

Rotgers, G. (2015). Beducht op leverbot bij melkvee. Veehouder en veearts, editie rundveehouderij, 29, 18-19.

Sanchez-Vazquez, M. J. and Lewis, F. I. (2013). Investigating the impact of fasciolosis on cattle carcase performance. Veterinary Parasitology, 193, 307-311. doi: http://dx.doi.org/10.1016/j.vetpar.2012.11.030.

Schweizer, G., Braun, U., Deplazes, P. and Torgerson, P. R. (2005). Estimating the financial losses due to bovine fasciolosis in Switzerland. Veterinary Record, 157, 188-193. doi: http://dx.doi.org/10.1136/vr.157.7.188.

Sekiya, M., Zintl, A. and Doherty, M. L. (2013). Bulk milk ELISA and the diagnosis of parasite infections in dairy herds: a review. Irish Veterinary Journal, 66. doi: http://dx.doi.org/10.1186/2046-0481-6614.

Selemetas, N., Phelan, P., O'Kiely, P. and de Waal, T. (2015a). Cluster analysis of fasciolosis in dairy cow herds in Munster province of Ireland and detection of major climatic and environmental predictors of the exposure risk. Geospatial Health, 9, 271-279.

Selemetas, N., Phelan, P., O'Kiely, P. and de Waal, T. (2015b). The effects of farm management practices on liver fluke prevalence and the current internal parasite control measures employed on Irish dairy farms. Veterinary Parasitology, 207, 228-240. doi: http://dx.doi.org/10.1016/j.vetpar.2014.12.010.

Skuce, P. J. and Zadoks, R. N. (2013). Liver fluke A growing threat to UK livestock production. Cattle Practice, 21, 138-149.

Toet, H., Piedrafita, D. M. and Spithill, T. W. (2014). Liver fluke vaccines in ruminants: strategies, progress and future opportunities. International Journal for Parasitology, 44, 915-927. doi: http://dx.doi.org/10.1016/j.ijpara.2014.07.011.

Trouve, S., Degen, L. and Goudet, J. (2005). Ecological components and evolution of selfing in the freshwater snail Galba truncatula. Journal of Evolutionary Biology, 18, 358-370. doi: http://dx.doi.org/10.1111/j.1420-9101.2004.00831.x.

Vaessen, M., Veling, J., Frankena, K., Graat, E. and Klunder, T. (1998). Risk factors for salmonella Dublin infection on dairy farms. . Veterinary Quarterly, 20, 97-99. doi: http://dx.doi.org/10.1080/01652176.1998.9694848.

Winkelhagen, A. J. S., Mank, T., de Vries, P. J. and Soetekouw, R. (2012). Apparent TriclabendazoleResistant Human Fasciola hepatica Infection, the Netherlands. Emerging Infectious Diseases, 18, 1028-1029. doi: http://dx.doi.org/10.3201/eid1806.120302. 
60 | Wageningen Livestock Research, Louis Bolk Instituut, rapport 1029 


\section{Bijlage 1 Leverbotinstrument}

\section{Vraag}

\section{Bedrijfsparameters}

Gemiddeld aantal melk- en kalfkoeien (afgelopen jaar):

Gemiddeld aantal stuks jongvee (afgelopen jaar):

Ras (belangrijkste bloedvoering((en)):

Gemiddelde melkproductie (kg/koe/jaar):

Gemiddeld aantal schapen (afgelopen jaar):

Gemiddeld aantal lammeren (afgelopen jaar):

Naast melkvee en/of schapen ook andere dieren aanwezig op het bedrijf.

Totaal aantal hectares grasland, incl. natuurland (ha):

Grootte huiskavel

Berekende parameter: aantal MK/ha huiskavel (zegt iets over druk)

Gemiddelde leeftijd waarop vaarzen afkalven (maanden):

Is het bedrijf gangbaar/biologisch

Gemiddeld celgetal (*1000):

Gemiddeld aantal inseminaties (per koe/drachtigheid)

Is er een verschil in aantal benodigde inseminaties tussen zomer en winter?

Is er een verschil in aantal benodigde inseminaties

tussen pinken en koeien?

Percentage verwerpen koeien:

Tussenkalftijd (dagen):

Vervangingspercentage koeien:

Vervangingspercentage schapen:

Sterftecijfer melkkoeien (\%):

Sterftecijfer kalveren (\%):

Is er sterfte van geweide kalveren tijdens het weideseizoen of na opstallen?

Oorzaak sterfte geweide kalveren in najaar/winter?

Sterftecijfer pinken (\%):

Is er sterfte van geweide pinken (na opstallen) in het najaar of winter?

Oorzaak sterfte geweide pinken in najaar/winter?

Sterftecijfer schapen (\%):

Is er sterfte van schapen in najaar/winter?

Oorzaak sterfte schapen in najaar/winter?

Aflampercentage toegelaten ooien (obv percentage verwerpen ooien):

Oorzaak voor tegenvallend aflampercentage of hoog

percentage verwerpen?

Sterftecijfer lammeren (\%):

Is er sterfte van lammeren in najaar/winter?

Oorzaak sterfte lammeren in najaar/winter?

Sterfte t.g.v. leverbot vastgesteld door:

dierenarts/sectie/anders

\section{Specificatie}

aantal

aantal

ras: HF, MRIJ, BK,

$B S$, etc.

jaargemiddelde

aantal

aantal

$\mathrm{j} / \mathrm{n}$; specificatie

aantal ha

aantal ha

bereken

maanden

(G)angbaar,

(B)iologisch

jaargemiddelde

aantal

$\mathrm{j} / \mathrm{n}$; specificatie

$\mathrm{j} / \mathrm{n}$; specificatie

percentage

aantal dagen

percentage;

specificatie

percentage;

specificatie

percentage

percentage

$\mathrm{j} / \mathrm{n}$

<open>

percentage

$\mathrm{j} / \mathrm{n}$

<open>

percentage

$\mathrm{j} / \mathrm{n}$

<open>

percentage

<open>

percentage

$\mathrm{j} / \mathrm{n}$

<open>

$\mathrm{j} / \mathrm{n}$; specificatie
Invul/Score

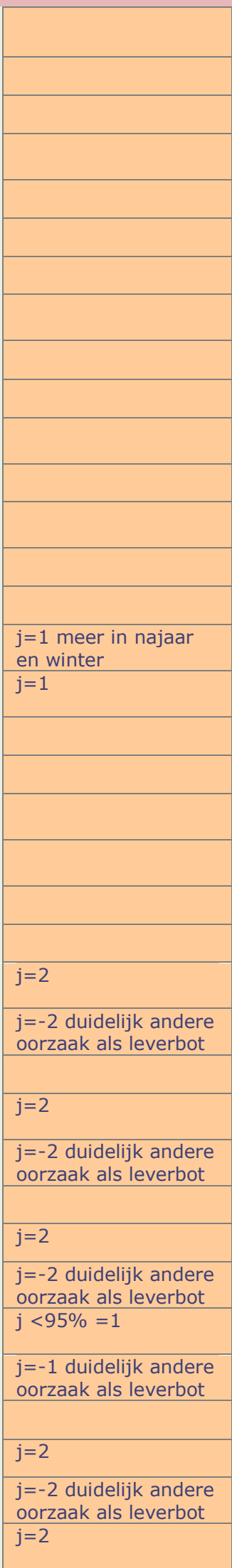


aanwijzingen bredere context sterfte t.g.v. leverbot (ziekten/tekorten/stoornissen/ed)?

\section{risico op leverbot}

\section{Gezondheid}

actuele gezondheid knelpunten: Salmonella

actuele gezondheidknelpunten: IBR

actuele gezondheidknelpunten: BVD

actuele gezondheidknelpunten: coccidiose bij kalveren actuele gezondheidknelpunten: klauwproblemen

actuele gezondheidknelpunten: mineralentekorten

actuele gezondheidknelpunten: vruchtbaarheid

actuele gezondheidknelpunten: overige

Wat was het belangrijkste gezondheidknelpunt van de laatste 2-3 jaar?

\section{risico op leverbot}

\section{Vaststelling leverbot}

Is sprake van een vastgestelde ACTUELE leverbotinfectie? vaststelling - recente positief tankmelkmonster vaststelling - recente positief bloedmonster vaststelling - recente positief mestmonster vaststelling - recent positieve grasland kartering (geïnfecteerde slakken)

vaststelling - recent afgekeurde levers lammeren (eventueel \%)

vaststelling - recente sterfte schapen/lammeren door leverbot

vaststelling - recente sterfte hazen/ aantreffen besmette hazen

vaststelling - recente leverbotprognose

vaststelling - recente leverbotsymptomen (welke?)

vaststelling - op het oog/ervaring: (omschrijving?)

vaststelling - andere recente indicatie(s):

Vermoed de veehouder een actuele besmetting? Op basis van?

Is er sprake van en een leverbothistorie?

vaststelling - positieve tankmelkmonsters

vaststelling - positieve bloedmonsters

vaststelling - positieve mestmonsters

vaststelling - positieve grasland kartering (geïnfecteerde slakken)

vaststelling - afgekeurde levers van geslachte koeien (eventueel \%)

vaststelling - afgekeurde levers lammeren vorig jaar (eventueel \%)

vaststelling - sterfte schapen/lammeren door leverbot

vaststelling - sterfte hazen/ aantreffen besmette hazen

vaststelling - leverbotprognose

vaststelling - leverbotsymptomen (welke?)

vaststelling - op het oog/ervaring: (omschrijving?)

vaststelling - andere indicatie(s):

Is leverbot jaarlijks vastgesteld de afgelopen 5 jaar

\section{kans op actuele leverbotbesmetting}

Invul/Score

$\mathrm{j} / \mathrm{n}$; verwacht neg effect van slechte klauwgez op prod

vrij, n/o of ja

vrij, n/o of ja

vrij, n/o of ja

$\mathrm{j} / \mathrm{n}$

$\mathrm{j} / \mathrm{n}$

$\mathrm{j} / \mathrm{n}$

$j / n$

$\mathrm{j} / \mathrm{n}$

<open>

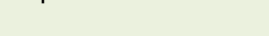

$\mathrm{j} / \mathrm{n} / \mathrm{o}$

$j / n$

$j / n$

$\mathrm{j} / \mathrm{n}$

$j / n$

$\mathrm{j} / \mathrm{n}$; percentage

$\mathrm{j} / \mathrm{n}$

$\mathrm{j} / \mathrm{n}$

$\mathrm{j} / \mathrm{n}$

$\mathrm{j} / \mathrm{n}$; specificatie

$\mathrm{j} / \mathrm{n}$; specificatie

$j / n$; specificatie

$j / n$; specificatie

$\mathrm{j} / \mathrm{n} / \mathrm{o}$

$\mathrm{j} / \mathrm{n}$

$\mathrm{j} / \mathrm{n}$

$j / n$

$j / n$

$\mathrm{j} / \mathrm{n}$; met eventueel percentage $\mathrm{j} / \mathrm{n}$; percentage

$j / n$

$\mathrm{j} / \mathrm{n}$

$j / n$

$\mathrm{j} / \mathrm{n}$; specificatie

$\mathrm{j} / \mathrm{n}$; specificatie

$j / n$; specificatie $j / n$ $j=-2$

maximaal 13

$j=2$

$j=1, n / 0=0.5$

$j=1$

$j=2$

$j=1$

$\mathrm{j}=1$

$j=2$

$j=1$

\section{maximaal 11}

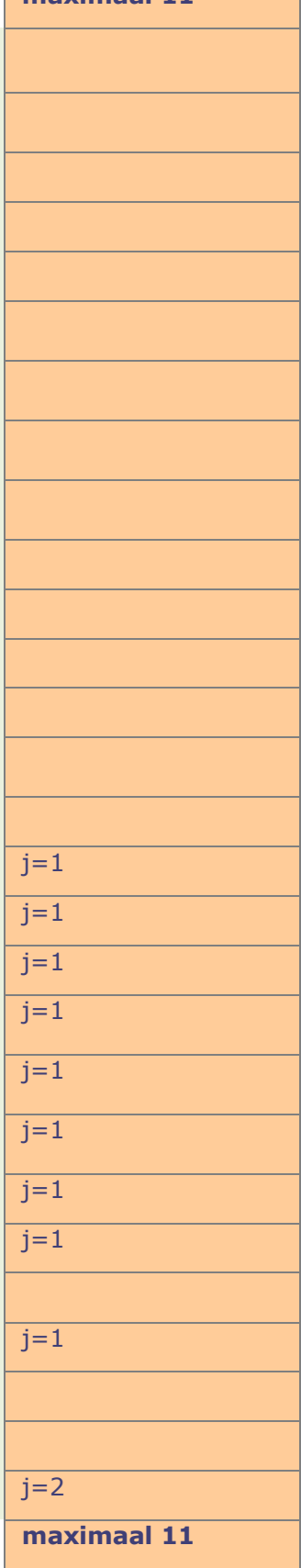




\section{Aanvoer en quarantaine}

aanvoer rundvee inclusief pinkenstier van buiten het bedrijf?

(een deel van) de jongveeopfok is uitbesteed?

heeft aangevoerd rundvee/terugkerend jongvee een vastgestelde leverbotbesmetting?

heeft aangevoerd rundvee/terugkerend jongvee

(mogelijk) op leverbotgevoeilige percelen geweid? (mogelijk) besmet rund- en jongvee krijgt de juiste quarantaine behandeling? (1. wegbehandelen alle leverbotstadia met middel met werkzame stof waartegen in NL nog geen resistentie bestaat +2 . gedurende 12 weken niet inscharen op leverbotgevoelige percelen) (mogelijk) besmet rund- en jongvee wordt pas ingeschaard op leverbotgevoelige bedrijfspercelen als op 12 weken na aanvoer/terugkeer is vastgesteld dat het mestmonster negatief is

Aanvoer fokooien, foklammeren, dekram(men) en/of weidelammeren?

hebben aangevoerde schapen/lammeren een

vastgestelde leverbotbesmetting?

worden aangevoerde schapen/lammeren (mogelijk)

geweid op leverbotgevoeilige percelen?

(mogelijk) besmette schapen/lammeren krijgen de juiste quarantaine behandeling? (1. wegbehandelen alle leverbotstadia met middel met werkzame stof waartegen in NL nog geen resistentie bestaat +2 . gedurende 12 weken niet inscharen op leverbotgevoelige percelen) (mogelijk) besmette schapen/lammeren worden pas ingeschaard op leverbotgevoelige bedrijfspercelen als op 12 weken na aanvoer/terugkeer is vastgesteld dat het mestmonster negatief is Inscharen schapen/lammeren van derden?

hebben ingeschaarde schapen/lammeren een vastgestelde leverbotbesmetting? worden ingeschaarde schapen/lammeren (mogelijk) geweid op leverbotgevoeilige percelen? (mogelijk) besmette bedrijfsvreemde schapen/lammeren zijn voor inscharen behandeld met een effectief middel en krijgen op tijd (afhankelijk van de toegepaste werkzame stof) de benodige herhalingsbehandelingen om eiuitscheiding door (mogelijk) meegebrachte leverbotten op gevoelige bedrijfspercelen te voorkomen.

uitscharen eigen schapen en/of lammeren op percelen van derden?

hebben eigen schapen/lammeren bij terugkeer op de bedrijfspercelen een vastgestelde leverbotbesmetting? worden eigen schapen/lammeren (mogelijk) geweid op leverbotgevoelige percelen van derden?

(mogelijk) besmette eigen schapen/lammeren zijn bij terugkeer behandeld met een effectief middel en krijgen op tijd (afhankelijk van de toegepaste werkzame stof) de benodigde herhalingsbehandelingen om eiuitscheiding door (mogelijk) meegebrachte leverbotten op gevoelige bedrijfspercelen te voorkomen.

\section{risico op insleep van (resistente) leverbot}

\section{Behandeling en resistentie}

Behandelingsnoodzaak bepaal ik op basis van:

Behandeld wordt op basis van een besmettingsvaststelling?

Behandeld wordt op basis van de leverbotprognose?

schapen worden behandeld tegen leverbot

Wanneer worden schapen behandeld tegen leverbot (momenten en intervallen)?

Met welk middel worden schapen behandeld?

Worden de schapen goed behandeld (niet te laat, te vroeg of te vaak)?

Gaan de schapen in het voorjaar schoon (vrij van

leverbot) de wei in $\mathrm{j} / \mathrm{n}$

$\mathrm{j} / \mathrm{n}$

$\mathrm{j} / \mathrm{n}$

$\mathrm{j} / \mathrm{n}$

$\mathrm{j} / \mathrm{n}$

$\mathrm{j} / \mathrm{n}$

$j / n$

$\mathrm{j} / \mathrm{n}$

$\mathrm{j} / \mathrm{n}$

$\mathrm{j} / \mathrm{n}$

$\mathrm{j} / \mathrm{n}$

$j / n$

$j / n$

$j / n$

$j / n$

$j / n$

$j / n$

$j / n$

$j / n$

$j=4$ en volgvraag

overslaan

$j=4$

$j=-2 ; n=2$

$j=-2 ; n=2$

=4 en volgvraag

overslaan

$j=4$

$j=-4$

tankmelk en mest

$j / n$

volgvraag overslaan

$\mathrm{j} / \mathrm{n}$

<open>

<open>

$\mathrm{j} / \mathrm{n}$

$\mathrm{j} / \mathrm{n}$ $n=2, j=0$ en

$j=0, n=2$

$j=4$ en volgvraa

overslaan

$j=4$

$j=-4$

maximaal 20

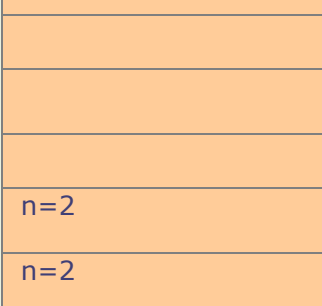


112 Wanneer worden melkkoeien behandeld tegen leverbot (momenten en intervallen)?

113 Met welk middel worden melkkoeien behandeld?

114 Worden de melkkoeien goed behandeld (niet te laat, te vroeg of te vaak)?

115 Gaan de melkkoeien in het voorjaar schoon (vrij van leverbot) de wei in

116 jongvee wordt behandeld tegen leverbot

117 Wanneer wordt jongvee behandeld tegen leverbot (momenten en intervallen)?

118 Met welk middel worden jongvee behandeld?

119 Wordt het jongvee goed behandeld (niet te laat, te vroeg of te vaak)?

120 Gaat jongvee in het voorjaar schoon (vrij van leverbot) de wei in

121 Ik bepaal het levend gewicht van het vee door:

122 Voor dosering wordt uitgegaan van levend gewicht van het KALF van:

123 Voor dosering wordt uitgegaan van levend gewicht van een PINK van:

124 Voor dosering wordt uitgegaan van levend gewicht van een DRACHTIGE VAARS van:

125 Voor dosering wordt uitgegaan van levend gewicht van een DROGE KOE van:

126 Voor dosering wordt uitgegaan van levend gewicht van een MELKKOE van:

127 Voor dosering wordt uitgegaan van levend gewicht van een LAM van:

128 Voor dosering wordt uitgegaan van levend gewicht van een SCHAAP van:

129 Bestaat de indruk dat op basis de genoemde levend gewichten van de diverse diercategorieën (vs normen) wordt ondergedoseerd?

130 De dosering wordt gecontroleerd via:

131 Behandelingen tegen leverbot zijn volgens veehouder effectief.

132 Met mestonderzoek wordt (regelmatig) vastgesteld of de behandeling (nog) effectief is

133 Op het bedrijf is resistentie bij leverbot vastgesteld tegen:

134 Alle dieren worden uitsluitend behandeld met een middel waartegen leverbotten op het bedrijf nog geen resistentie hebben maatregel: gebruik alternatieve middelen tegen leverbot is het toegepaste alternatieve middel $100 \%$ effectief

\section{7 risico op fout behandelen}

\section{Leverbotgevoelige percelen}

140 Beweidt u?

141 Op hoeveel van het totale areaal grasland weidt $\mathrm{u}$ (melk)vee?

142 Vul de uren-weiden-tabel (los toegevoegd) in

143 Grondsoort (overwegend):

144 leverbotgevoelige percelen.

145 percentage leverbotgevoelig percelen.

146 Percelen met greppels die regelmatig/langere tijd volstaan met water

147 Percentage percelen met waar regelmatig/langere tijd water in de greppels staat?

148 In welke periode(n) staan greppels vol/staat water in de greppels?

149 percelen waar langdurig plassen staan.

150 percentage percelen waar langdurig plassen staan $j / n$

$\mathrm{j} / \mathrm{n}$

$\mathrm{j} / \mathrm{n}$

<open>

<open>

$\mathrm{j} / \mathrm{n}$

$\mathrm{j} / \mathrm{n}$

m(eten), $\mathrm{s}$ (chatten) of w(egen)

$\mathrm{kg}$

$\mathrm{kg}$

$\mathrm{kg}$

$\mathrm{kg}$

$\mathrm{kg}$

$\mathrm{kg}$

$\mathrm{kg}$

$\mathrm{j} / \mathrm{n} / \mathrm{o}$

$\mathrm{j} / \mathrm{n}$; met

maatverdeling

$\mathrm{j} / \mathrm{n} / \mathrm{o}$

$\mathrm{j} / \mathrm{n}$

middel

$j / n$

$\mathrm{j} / \mathrm{n}$; specificatie

$\mathrm{j} / \mathrm{n}$

$\mathrm{j} / \mathrm{n}$

aantal ha

$\mathrm{j} / \mathrm{n}$

KLEI, KLOV, VEEN, ZAND

$\mathrm{j} / \mathrm{n}$

percentage

$\mathrm{j} / \mathrm{n}$

percentage

jaarrond, najaar, natte perioden

$\mathrm{j} / \mathrm{n}$

percentage
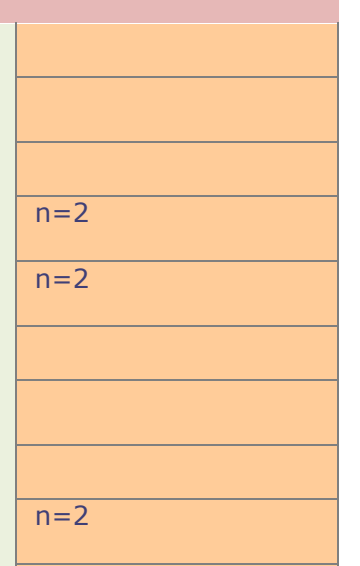

$n=2$

$w=-2, m=1, s=2$

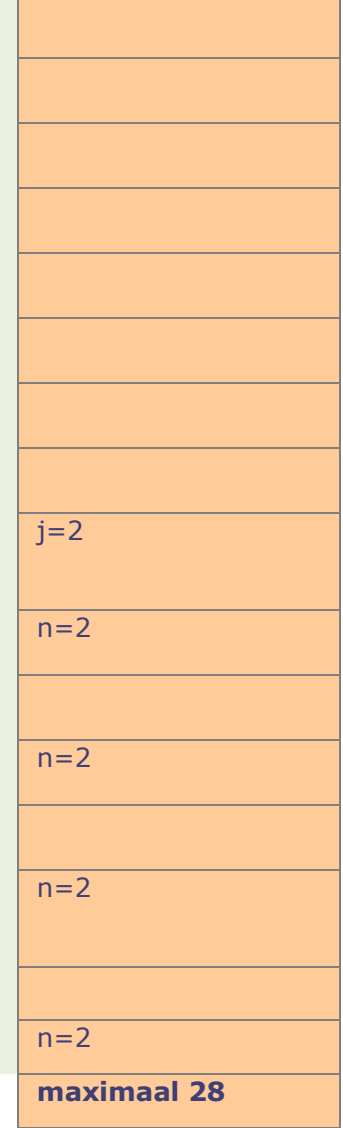

maximaal 28 
Wanneer freest u greppels?

154

\section{VIII}

Winterpeil sloten is percelen: plekken niet meegemaaid) plekken niet meegemaaid) plekken niet meegemaaid) ontwijkend te beweiden permanent uitgerasterd zomer gefreest

\section{Vraag}

Wanneer staan er plassen op de percelen? dan zomerpeil.

melkkoeien grazen op leverbotgevoelige percelen:

droge koeien grazen op leverbotgevoelige percelen:

drachtige vaarzen grazen op leverbotgevoelige percelen:

pinken grazen op leverbotgevoelige percelen:

kalveren grazen op leverbotgevoelige percelen:

eigen schapen/geiten grazen op leverbotgevoelige

ingeschaarde schapen van derden grazen op

leverbotgevoelige percelen:

overige dieren grazen op leverbotgevoelige percelen

\section{risico op besmetting met leverbot}

\section{Overige preventieve maatregelen}

bedrijf neemt maatregelen om leverbot te beperken

zomerstalvoeding: melkkoeien (indien greppels en natte

zomerstalvoeding: droge koeien (indien greppels en natte plekken niet meegemaaid)

zomerstalvoeding: pinken (indien greppels en natte

zomerstalvoeding: kalveren (indien greppels en natte

maatregel: toepassing beweidingsplan om besmetting

maatregel: natte plekken/greppels in percelen zijn

maatregel: alle percelen zijn gedraineerd

maatregel: i.g.v. periodieke wateroverlast actieve ontwatering waardoor geen water in de greppels blijft staan en geen plassen op het land blijven staan

maatregel: aangepast slootkantbeheer

maatregel: vaste drinkpunten

maatregel: greppelbeheer; de greppels worden in de

maatregel: aangepast peilbeheer

maatregel: (vroeg) opstallen dieren indien nodig

maatregel: weerstand vee verhogen

maatregel: effectief gebruik middelen om

slakkenpopulatie te reduceren (bijvoorbeeld eenden)

andere (toekomstige) preventieve maatregelen jaarrond, najaar, natte perioden lager / hoger /

zelfde

nooit / voorjaar /

zomer / najaar /

winter

$\mathrm{j} / \mathrm{n}$

$\mathrm{j} / \mathrm{n}$

$\mathrm{j} / \mathrm{n}$

$\mathrm{j} / \mathrm{n}$

$\mathrm{j} / \mathrm{n}$

$j / n$

$j / n$

$\mathrm{j} / \mathrm{n}$; specificatie

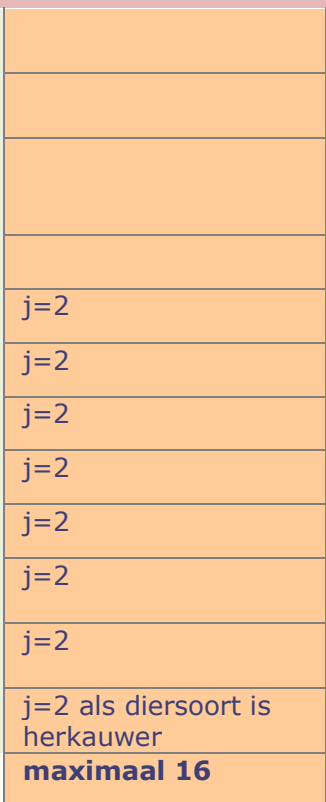

\section{rapportcijfer preventieve maatregelen excl. quarantaine}

$\mathrm{j} / \mathrm{n}$

$\mathrm{j} / \mathrm{n}$

$\mathrm{j} / \mathrm{n}$

$\mathrm{j} / \mathrm{n}$

$j / n$

$j / n$

j tijdelijk tot in het najaar/maaien 'schoon'land $\mathrm{j} / \mathrm{n} /$ deels; specificatie $\mathrm{j} / \mathrm{n}$; specificatie

$\mathrm{j} / \mathrm{n}$; specificatie $j / n$

$\mathrm{j} / \mathrm{n}$; specificatie

$\mathrm{j} / \mathrm{n}$; specificatie

$\mathrm{j} / \mathrm{n}$; specificatie

$\mathrm{j} / \mathrm{n}$; specificatie

$\mathrm{j} / \mathrm{n}$; specificatie

$\mathrm{j} / \mathrm{n}$; specificatie

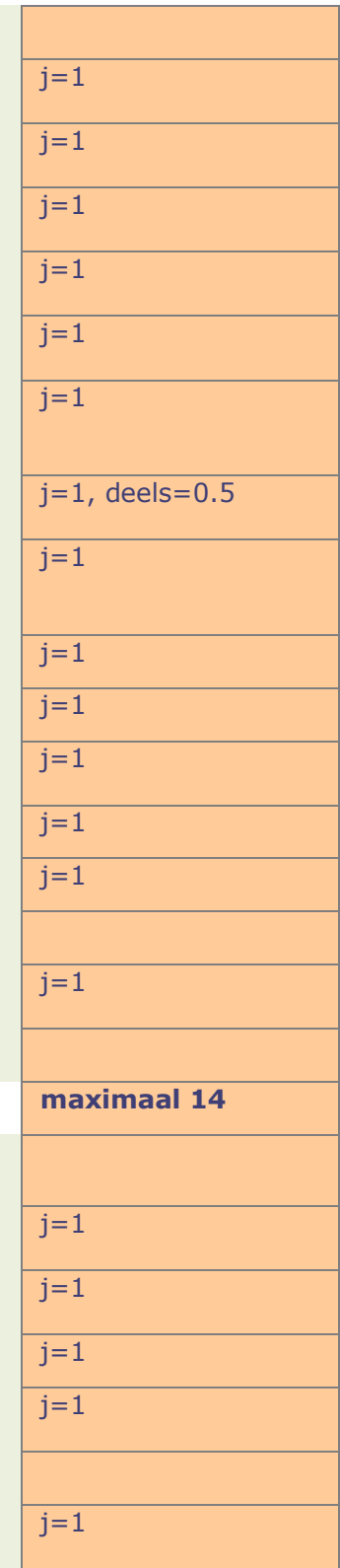


191 Veehouder weet welke factoren een rol spelen bij de opbouw van een besmetting

192 Veehouder weet wanneer en waardoor besmettingen worden afgezet door de slak.

193 Veehouder is ter zake kundig en handelend wat betreft behandeling (te laat te vroeg te vaak)

194 Veehouder is ter zake kundig en handelend wat betreft quarantaine (te laat te vroeg te vaak)

195 Veehouder weet welke factoren resistentie ontwikkeling in de hand werken en handelt ernaar

196 Benoemt de veehouder naast sterfte andere schade door leverbot?

$\mathrm{j} / \mathrm{n}$

$\mathrm{j} / \mathrm{n}$

$\mathrm{j} / \mathrm{n}$

$j / n$

$\mathrm{j} / \mathrm{n}$

$\mathrm{j} / \mathrm{n}$

$\mathrm{j} / \mathrm{n}$; specificatie $j=1$

$j=1$

$j=1$

$j=1$

$j=1$

$j=1$

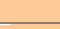

maximaal 11 


\section{Bijlage 2 Lijst met figuren en tabellen}

Figuur 1 Geografische spreiding van in Nederland aangetoonde leverbotinfecties (middels

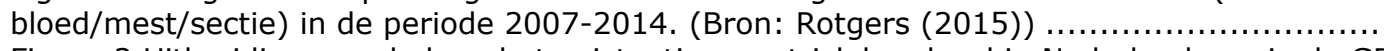
Figuur 2 Uitbreiding van de leverbotresistentie voor triclabendazol in Nederland op via de GD

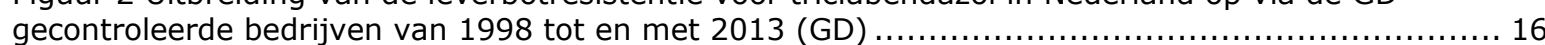

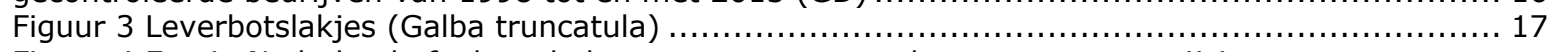
Figuur 4 Een in Nederland afgekeurde lever met vergrote galgangen met aanwijzingen voor ontsteking.... Figuur 5 Risico op leverbotbesmetting in Nederland (definitieve prognose 2015)(bron:

http://www.gddiergezondheid.nl/producten\%20en\%20diensten/producten/leverbot/leverbotadvies) 24 Figuur 6 Geografische initiële selectie van de ca 420 bedrijven op basis van de uitslag van tankmelkonderzoek op leverbotantistoffen en monsternamedatum (dataset Merial)

Figuur 713 geselecteerde matches van leverbot positieve en negatieve 'buurbedrijven

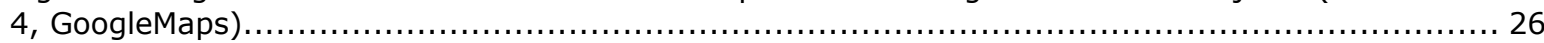

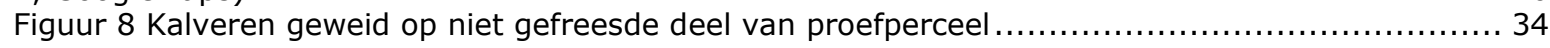

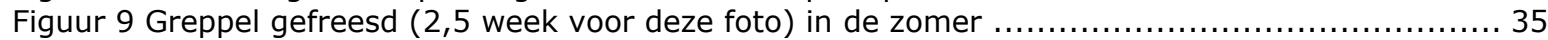

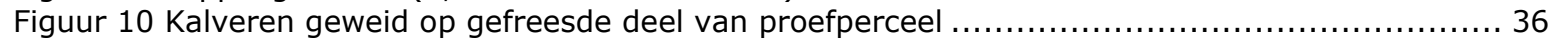

Figuur 11 Ontwijkend beweiden met schrikdraad langs drassige slootkant ........................40 Figuur 12 Ontwijkend maaien voor zomerstalvoedering - greppels niet mee gemaaid .....................4 41

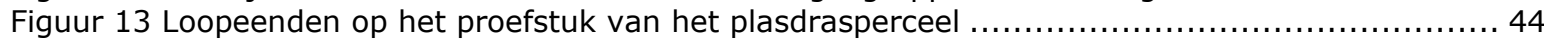
Figuur 14 Schematische weergave van de leverbot-besmettingsroute, met de bijbehorende schade, en de mogelijke wijzen van vaststellen van de besmetting van een perceel, de slak en het dier ..........48

Tabel 1 Onderdelen van het ontwikkelde leverbotinstrument

Tabel 2 Interpretatie Idexx Elisa testuitslagen antilichamen Fasciola hepatica in bloed en melk (VLG

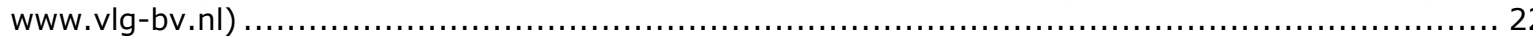
Tabel 3 Het aantal getapte bedrijven op basis van de selectie van matchende positieve en negatieve

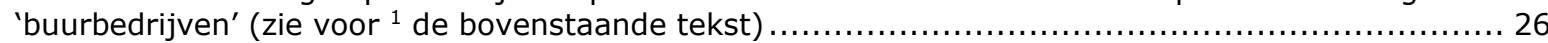
Tabel 4 Aantal geselecteerde (en waar ook bloedmonsters zijn genomen en bedrijfsbezoek heeft plaats gevonden) en werkelijk gemaakte matches voor analyse op basis van de uitslagen van de bloedtiters van een leverbot positief en negatief bedrijf....

Tabel 5 Percentage positieve runderen per diergroep per bedrijf in de match .......................... 28

Tabel 6 Weergave van de leverbot positieve en negatieve bedrijven die gematched zijn opgesplitst naar type bedrijf: aantal koeien, jongvee en de melkproductie....

Tabel 7 Besmettingsstatus van het jongvee en het melkvee op basis van bloedmonsters van de 25

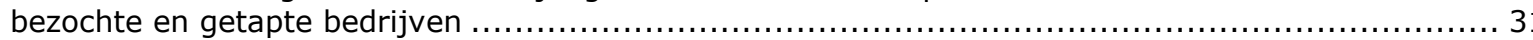

Tabel 8 Vergelijking hoeveelheid leverbotantistoffen in bloed (OD-waarde) en leverbotstatus (positief/negatief) van kalveren geweid op het in de zomer gefreesde deel van het perceel met kalveren geweid op niet gefreesde deel van het perceel in 2015.

Tabel 9 Vergelijking goed en slecht drachtig geraakte melkkoeien op aantal dagen in lactatie, kalfdatum, pariteit, lactatiewaarde, inseminatienummer, drachtigheid en hoeveelheid

leverbotantistoffen in bloed (OD-waarde) in 2015 37 Tabel 10 Monitoring individuele en gemiddelde hoeveelheid leverbotantistoffen in bloed (OD-waarde) en leverbotstatus (positief/negatief) bij verschillende categorieën rundvee op twee momenten in 2015

Tabel 11 Leverbotantistoffen in bloed (OD-waarde) jongvee, maatregel ontwijkend beweiden (tapdatum 11/9/2015 en 16/12/2015) 


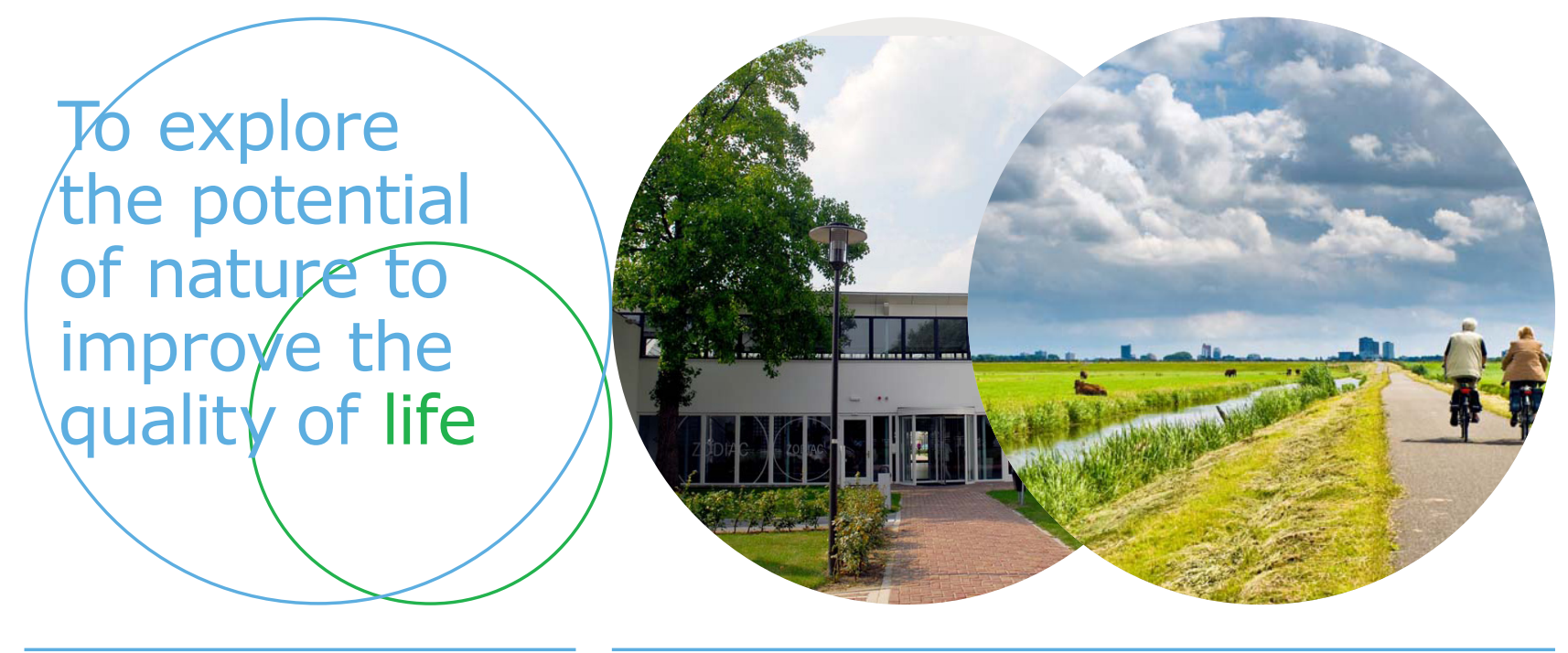

Wageningen Livestock Research Postbus 338

$6700 \mathrm{AH}$ Wageningen

T 0317483953

E info.livestockresearch@wur.nl www.wur.nl/livestock-research
Louis Bolk Instituut

Hoofdstraat 24

3972 LA Driebergen

T 0343523860

E info@louisbolk.nl

www.louisbolk.nl 